University of Nebraska - Lincoln

DigitalCommons@University of Nebraska - Lincoln

1984

\title{
Correlation of the middle Eocene Kellogg Shale of northern California
}

John A. Barron

USGS

David Bukry

USGS

Richard Z. Poore

USGS

Follow this and additional works at: https://digitalcommons.unl.edu/usgsstaffpub

Part of the Earth Sciences Commons

Barron, John A.; Bukry, David; and Poore, Richard Z., "Correlation of the middle Eocene Kellogg Shale of northern California" (1984). USGS Staff -- Published Research. 269.

https://digitalcommons.unl.edu/usgsstaffpub/269

This Article is brought to you for free and open access by the US Geological Survey at DigitalCommons@University of Nebraska - Lincoln. It has been accepted for inclusion in USGS Staff -- Published Research by an authorized administrator of DigitalCommons@University of Nebraska - Lincoln. 
John A. Barron ${ }^{1}$

\section{David Bukry 2}

\section{Richard Z. Poore ${ }^{3}$}

U.S. Geological Survey

'345 Middlefield Rd.

Menio Park, California 94025

${ }^{2}$ Scripps Institution of Oceanography

La Jolla, California 92093

${ }^{3} 12201$ Sunrise Valley Dr.

Reston, Virginia 22092

\section{Correlation of the middle Eocene Kellogg Shale of northern California}

\section{ABSTRACT}

The Kellogg Shale of northern California has traditionally been considered to be late Eocene in age on the basis of benthic foraminifer, radiolarian, and diatom correlations. The $30-\mathrm{m}$ thick Kellogg section exposed west of Byron, California, however, contains middle Eocene planktonic foraminifers (Zone P12), coccoliths (Subzones CP13c and CP14a), silicoflagellates (Dictyocha hexacantha Zone), and diatoms. Quantitative studies of the silicoflagellates and diatoms show a general cooling trend through the section which is consistent with paleoclimatic trends for this part of the middle Eocene (ca. 42-45 Ma) from elsewhere in the world. Seven new silicoflagellate taxa (Corbisema angularis, C. exilis, C. hastata miranda, $C$. inermis ballantina, $C$. regina, Dictyocha byronalis, Naviculopsis americana) and one new coccolithophorid species (Helicosphaera neolophota) are described.

\section{INTRODUCTION}

For over 25 years the Kellogg Shale of Clark and Campbell (1942) in northern California has been recognized as a standard North American reference unit for Eocene siliceous microfossils. Clark and Campbell's (1942) study was one of the earliest on North American Cenozoic radiolarians, and Kanaya's (1957) report on the diatoms helped to pioneer techniques for modern deep-sea studies. Subsequent studies on the silicoflagellates (Mandra 1960, 1968; Ling 1972), planktonic foraminifers (Schmidt 1970), and coccoliths (Schmidt 1970; Almgren and McDougall 1975) further demonstrated the value of the Kellogg Shale as a reference unit for planktonic correlations.

The Kellogg Shale traditionally has been considered upper Eocene by diatom workers on the basis of Kanaya's (1957) assignment. Kanaya assigned the Kellogg Shale to the upper Eocene because it was underlain by the Domengine Sandstone which contains middle Eocene mollusks and because he correlated the Kellogg Shale to the nearby Sidney Shale Member of the Markley Formation of Clark and Campbell (1942) (= Sidney Flat Shale and Sidney Shale of some authors). The Sidney Shale was assigned to Laiming's (1940) A-2 zone of benthic foraminifers, which was considered to be late Eocene at that time. Similarly, early correlations using silicoflagellates described the Kellogg Shale as upper Eocene (Mandra 1960, 1968) or middle or upper Eocene (Ling 1972). Fenner (1977) stated, "the Kellogg and Sidney shales fall into the lower part of P15 of Blow (1969)" (planktonic foraminifer zone) on the basis of Kanaya and Koizumi's (1970) correlations. It appears, however, that Kanaya and Koizumi's assignment was made by inference because Schmidt (1970) had correctly assigned the Kellogg and the Sidney to the middle Eocene in his unpublished $\mathrm{PhD}$ dissertation on the basis of planktonic foraminifers and coccoliths. More recently, Jousé (1979) demonstrated the traditional position of diatom workers by assigning the Kellogg shale diatom assemblages to her early late Eocene Hemiaulus polycystinorum-Triceratium barbadense assemblage zone.

Correlations of the Kellogg Shale to the middle Eocene have not been widely circulated in the literature. Schmidt's (1970) study of the planktonic foraminifers and coccoliths was an unpublished $\mathrm{PhD}$ dissertation. Almgren and McDougall's (1975) summary paper on the Kellogg Shale correlations was published in a local California publication. More recently, Ehrlich and Moshkovitz (1982) noted that the characteristic diatom species of the Kellogg Shale [i.e., Melosira architecturalis Brun, Craspedodiscus oblongus (Greville) Grunow, Triceratium barbadense Greville, T. inconspicuum Greville, and $T$. brachiatum Brightwell] occur both in the middle Eocene Maresha Member of the Zora Formation in Israel and in middle Eocene sediments from DSDP Site 356 in the South Atlantic. 
TABLE 1

Stratigraphic interval (in meters) above the top of Donengine Sandstone of the three series of samples collected from Kellogg Shale.

\begin{tabular}{|c|c|c|c|}
\hline CD-series & $\begin{array}{l}\text { Stratigraphic } \\
\text { Interval (m) }\end{array}$ & $\mathrm{K}$-series & $\begin{array}{l}\text { Stratigraphic } \\
\text { Interval (m) }\end{array}$ \\
\hline 23 & 23.2 & 12 & 19.7 \\
\hline 22 & 21.6 & 11 & 18.8 \\
\hline 21 & 20.0 & 10 & 17.7 \\
\hline 20 & 18.8 & 9 & 15.5 \\
\hline 19 & 18.0 & 8 & 14.2 \\
\hline 18 & 15.9 & 7 & 13.0 \\
\hline 17 & 15.2 & 6 & 12.5 \\
\hline 16 & 13.2 & 5 & 9.6 \\
\hline 15 & 12.3 & 4 & 8.0 \\
\hline 14 & 11.5 & 3 & 6.0 \\
\hline 13 & 9.6 & 2 & 4.2 \\
\hline 12 & 8.7 & 1 & 2.0 \\
\hline 11 & 7.9 & & Stratigraphic \\
\hline 10 & 7.1 & 0 -series & Interval (m) \\
\hline 9 & 5.6 & 4 & 20 \\
\hline 8 & 4.5 & 3 & 13 \\
\hline 7 & 3.6 & 2 & 8 \\
\hline 6 & 2.4 & 1 & 4.5 \\
\hline 5 & 1.5 & & \\
\hline 4 & 1.0 & & \\
\hline 3 & 0.8 & & \\
\hline 2 & 0.4 & & \\
\hline
\end{tabular}

In order to confirm the middle Eocene age and to more thoroughly document the planktonic microfossil assemblages, we decided to study the diatoms (Barron), planktonic foraminifers (Poore), coccoliths and silicoflagellates (Bukry) of the Kellogg Shale. Radiolarians are also abundant in the Kellogg Shale and are presently being studied by Joyce Blueford of the U.S. Geological Survey and Charlotte Brunner of the University of California, Berkeley. We hoped to provide updated correlations as well as some paleoecological interpretations.

\section{MATERIALS AND METHODS}

Kanaya's (1957) section of the Kellogg Shale along Camino Diablo Road about $1 \frac{1}{2}$ mi west of the town of Byron in Contra Costa County, California (text-fig. 1) was sampled for study of the diatoms, coccoliths, silicoflagellates and planktonic foraminifers. Thirty-eight sediment samples were taken on three separate visits (4 of the " $O$ " series in 1975, 12 of the "K" series in 1977, and 22 of the "CD" series in 1981) (table 1). Field samples represent 2 to $3 \mathrm{~cm}$ of stratigraphic section; prepared samples are somewhat smaller depending on the microfossil group studied. The stratigraphic intervals of the "O" and " $K$ " samples were estimated by pacing, whereas the "CD" samples were measured stratigraphically by steel tape and Brunton Compass.

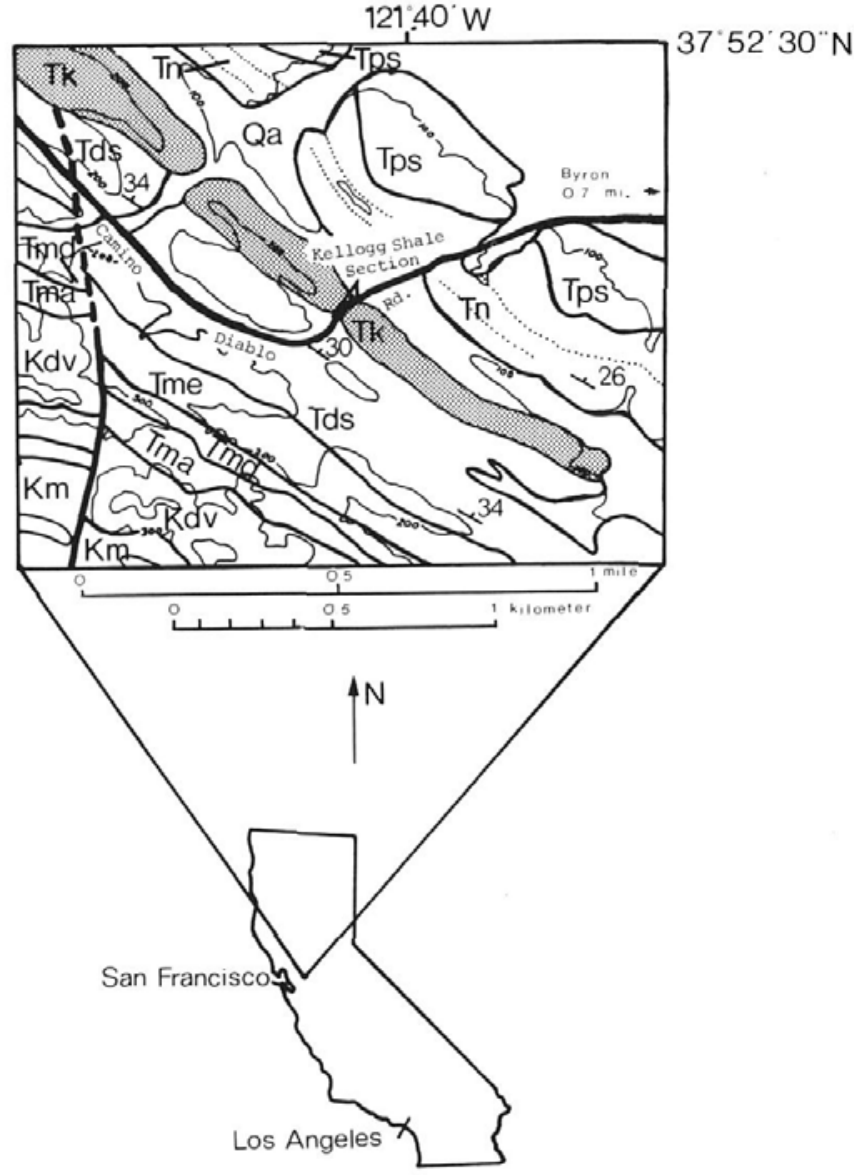

TEXT-FIGURE 1

Outcrop pattern of middle Eocene Kellogg Shale (shaded) in Sections 6 and 8, T1S, R3E, Byron Hot Springs 71/2' Quadrangle, northern California. $\mathrm{Qa}=$ Quaternary alluvium; Tps = Pliocene nonmarine sedimentary rocks; $\mathrm{Tn}=$ upper Miocene Neroly Formation; $\mathrm{Tk}=$ middle Eocene Kellogg Shale (mapped as Kreyenhagen Shale by Dibblee 1980); Tds = middle Eocene Domengine Sandstone; Tme, Tmd, Tma = members of the Paleocene Meganos Formation; $\mathrm{Km}=$ Cretaceous Moreno Formation; Kdv = Cretaceous Deer Valley Formation of Colburn (1964). Map after Dibblee 1980.

Thirty $\mathrm{m}(98 \mathrm{ft})$ of laminated and massive diatomaceous shale corresponding to the Kellogg Shale were measured in the road cut above the basal contact with the Domengine Sandstone. This thickness agrees well with 90-ft thickness estimated by Kanaya (1957). The upper unconformable contact with the. overlying nonmarine Neroly Formation is not exposed in the immediate area (Dibblee 1980).

Whole sediment smear slides were examined for coccoliths, and a nonquantitative checklist of all taxa encountered was prepared. Diatom and silicoflagellate samples were processed in hydrochloric acid and hydrogen peroxide following the technique outlined in Barron (1976). Acid-residue slides were traversed, and separate counts of 300 diatoms and 300 silicoflagellates were 
TABLE 2

Checklist of middle Eocene coccoliths from Camino Diablo Road outcrop of the Kellogg Shale. Other samples from the three sample series (table 1) are barren of coccoliths. Abundance is estimate of density of coccoliths relative to other sediment present on smear slide. Preservation scale from Bukry (1973a) $(-4=$ specimens strongly etched, fragmented to $-1=$ specimens slightly etched, eas. ily identifiable). Zonation is from Okada and Bukry (1980). $X=$ present; $\otimes=$ ex ceptionally abundant; $A=$ abundant; $C=$ common; $F=$ few; $R=$ rare. ${ }^{*}$ signifies composite assemblages of nearly stratigraphically equivalent samples from two or three of the sample series; the most diverse sample is listed here.

\begin{tabular}{|c|c|c|c|c|c|c|c|c|c|c|c|}
\hline \multirow{3}{*}{$x a$} & \multirow{3}{*}{$\begin{array}{l}\text { Subzone } \\
\text { Series } \\
\text { Sample \# }\end{array}$} & \multicolumn{8}{|c|}{ CP14a } & \multicolumn{2}{|c|}{ CP13c } \\
\hline & & 0 & 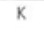 & k & $C D$ & CD & CD & K & $C D$ & $\mathrm{CD}$ & $\mathrm{CO}$ \\
\hline & & * & $6^{*}$ & 5 & 12 & $1^{\star}$ & 10 & 3 & $8 *$ & 5 & \\
\hline \multirow{13}{*}{\multicolumn{2}{|c|}{ 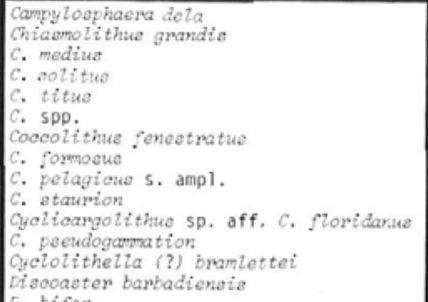 }} & & $=$ & - & & $x$ & & 8 & - & & \\
\hline & & & $x$ & - & - & & $x$ & & $x$ & & \\
\hline & & & - & - & - & $x$ & - & - & $x$ & $x$ & \\
\hline & & & $x$ & $x$ & & & - & $x$ & 음 & - & \\
\hline & & & & - & - & $x$ & - & - & $\bar{x}$ & - & \\
\hline & & & - & - & - & - & $x$ & - & - & - & \\
\hline & & & $=$ & - & & & - & $x$ & - & & \\
\hline & & & & $x$ & & $x$ & $x$ & - & $x$ & $x$ & \\
\hline & & & $x$ & $x$ & $x$ & & $x$ & $x$ & $x$ & $\mathrm{x}$ & \\
\hline & & & $\bar{x}$ & $=$ & $=$ & $?$ & $\bar{x}$ & $\bar{x}$ & $x$ & : & \\
\hline & & & $\hat{x}$ & $=$ & - & $\bar{x}$ & $\begin{array}{l}x \\
-\end{array}$ & X & $\bar{x}$ & $\overline{-}$ & \\
\hline & & & - & - & - & & - & - & $\hat{x}$ & - & \\
\hline & & & & - & & & - & $x$ & $x$ & $x$ & \\
\hline \multirow{3}{*}{\multicolumn{2}{|c|}{$\begin{array}{l}\text { D. bifax } \\
\text { D. sp. aff. D. bifax (early) } \\
\text { D. deflandrei }\end{array}$}} & & & $x$ & $x$ & $x$ & $x$ & - & $=$ & 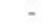 & \\
\hline & & & & - & & & & - & $\mathrm{x}$ & - & \\
\hline & & & & $\bar{x}$ & $\begin{array}{l}x \\
x\end{array}$ & $\begin{array}{l}X \\
x \\
x\end{array}$ & - & - & $x$ & $x$ & \\
\hline \multicolumn{2}{|c|}{$\begin{array}{l}\text { deflandrei } \\
\text { dietinetue }\end{array}$} & & $\begin{array}{l}x \\
x\end{array}$ & $\begin{array}{l}x \\
x\end{array}$ & & $\begin{array}{l}x \\
x\end{array}$ & & $\bar{x}$ & - & - & \\
\hline \multicolumn{2}{|l|}{ D. Sp. at } & & $\hat{x}$ & - & 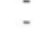 & & & $\begin{array}{l}x \\
-\end{array}$ & - & - & \\
\hline \multicolumn{2}{|l|}{ D. nodifer } & & & - & & - & $n$ & - & - & 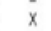 & \\
\hline \multirow{2}{*}{\multicolumn{2}{|c|}{$\begin{array}{l}\text { D. atrictuo } \\
\text { Diecolithina dietincta }\end{array}$}} & & & - & $x$ & - & & - & $?$ & & \\
\hline & & & - & $\theta$ & & & - & - & $x$ & & \\
\hline \multicolumn{2}{|l|}{$\begin{array}{l}\text { ecolithina distincta } \\
\text { plana }\end{array}$} & & & $\bar{x}$ & $\dot{x}$ & $\bar{x}$ & - & - & & $x$ & \\
\hline \multicolumn{2}{|l|}{$\begin{array}{l}\text { Helicoophaera bramlettei } \\
\mathrm{H} \text {. sp. aff. heezenit }\end{array}$} & & & 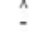 & $x$ & $x$ & $=$ & : & $\mathrm{x}$ & $\begin{array}{l}x \\
x\end{array}$ & \\
\hline \multirow{2}{*}{\multicolumn{2}{|c|}{ H. Zophota }} & & & - & - & $x$ & & - & - & $\hat{x}$ & \\
\hline \multirow{2}{*}{\multicolumn{2}{|c|}{$\begin{array}{l}\text { H. neolophota } \\
\text { Markal ine inveroue } \\
\text { Micrantholithe aequalie }\end{array}$}} & & & - & - & & - & $x$ & & $x$ & \\
\hline & & & & - & - & & - & - & - & $x$ & \\
\hline \multirow{2}{*}{\multicolumn{2}{|c|}{$\begin{array}{l}\text { Wionationtiue aequalie } \\
\text { A. inaequatis }\end{array}$}} & & & $\bar{x}$ & $\bar{x}$ & $\begin{array}{l}x \\
x\end{array}$ & - & $\bar{x}$ & $\bar{x}$ & & \\
\hline \multirow{2}{*}{\multicolumn{2}{|c|}{ Nannotetrina crietata }} & & & $\hat{B}$ & $\hat{x}$ & $\hat{x}$ & 8 & : & $\hat{x}$ & $x$ & \\
\hline & & & & - & - & - & & - & & & \\
\hline & & & - & & - & & - & & & \\
\hline \multirow{2}{*}{\multicolumn{2}{|c|}{$\begin{array}{l}\text { Reticulofenestra samodurovit } \\
\text { R. umbilioa }\end{array}$}} & & & $=$ & $\begin{array}{l}x \\
x\end{array}$ & $x$ & - & 8 & $x$ & a & \\
\hline & & & & - & $x$ & $x$ & & $x$ & $\bar{x}$ & & \\
\hline \multicolumn{2}{|l|}{$\begin{array}{l}\text { R. spp. } \\
\text { Frabdoophaera sp. aff. R. arebra }\end{array}$} & & & $z$ & 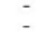 & & - & - & $\begin{array}{l}x \\
x\end{array}$ & - & \\
\hline R. sp. cf. R. morionam & & & & - & - & - & - & - & $\hat{x}$ & - & \\
\hline R. ерілица & & & & $x$ & $=$ & - & 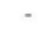 & - & & & \\
\hline & & & & - & $\mathrm{x}$ & $x$ & & 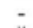 & - & & \\
\hline & & & 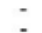 & 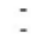 & - & - & $x$ & $x$ & - & & \\
\hline & & & & 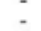 & $\bar{x}$ & $\begin{array}{l}x \\
x\end{array}$ & - & - & & $\mathrm{x}$ & \\
\hline & & & & $\mathrm{x}$ & - & 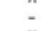 & - & - & $\hat{x}$ & - & \\
\hline & & & & $x$ & $\mathrm{x}$ & $n$ & - & $y$ & $x$ & & \\
\hline & & & $=$ & 8 & 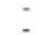 & $\underline{x}$ & - & $\underline{x}$ & & - & \\
\hline & & & & - & 8 & $x$ & - & - & $\hat{x}$ & $x$ & \\
\hline & & & & v & $=$ & $x$ & - & - & $x$ & & \\
\hline & & & & $\begin{array}{l}X \\
A\end{array}$ & a & x & $\bar{F}$ & $\bar{c}$ & & & \\
\hline & & & & & & & & & & & \\
\hline
\end{tabular}

made. Diatom counts were made at $1250 \times$, and specimens of the incertae sedis form Macrora barbadensis (Deflandre) Bukry were included in the tabulation, but resting spores of the genera Xanthiopyxis and Lyradiscus were not. Silicoflagellate counts were made at 250 to $500 \times$, and Macrora was also tabulated.

Foraminifer samples were disaggregated using either solvent, dilute hydrogen peroxide solution or both and then wet sieved at $63 \mu \mathrm{m}$. The dried residue $\geq 63 \mu \mathrm{m}$ was examined for foraminifers. Siliceous microfossils and debris make up most of the washed residue, and the siliceous component tended to mask the foraminifers. In order to estimate the abundance of individual foraminiferal taxa, a dense layer of washed residue $\geq 149 \mu \mathrm{m}$ was strewn on a standard 60 square microfossil slide. Taxa represented by more than 20 specimens on the strewn slide were tabulated as abundant, those represented by
5-20 specimens were considered common, and those represented by 1-5 specimens were considered few. Taxa occurring at lower frequencies or only in the $\geq 149$ $\mu \mathrm{m}$ size fraction were considered sparse.

\section{BIOSTRATIGRAPHY}

Coccoliths

Eocene coccoliths are sparse to abundant in the lower $14 \mathrm{~m}$ of the Camino Diablo Road section of the Kellogg Shale section. The assemblages are generally diverse with shallow marine taxa such as Discolithina, Micrantholithus and Zygrhablithus (table 2). Zonal assignment of the basal $3 \mathrm{~m}$ to the Coccolithus staurion Subzone (CP13c) and the overlying $11 \mathrm{~m}$ to the superjacent Discoaster bifax Subzone (CP14a) is based on the range of Nannotetrina quadrata (Bramlette \& Sullivan) in the lower interval and Discoaster bifax Bukry in the upper interval. Other taxa, such as Chiasmolithus grandis (Bramlette \& Riedel) Radomski and C. solitus (Bramlette \& Sullivan) Gartner, confirm a middle Eocene correlation of the Kellogg Shale.

Changes in dominance of coccolith taxa through the Kellogg section suggest ecologic changes from cool to warm in the replacement of dominant Chiasmolithus solitus at $4 \mathrm{~m}$ by Coccolithus formosus (Kamptner) Wise at $12 \mathrm{~m}$.

The increased dissolution of coccoliths at $14 \mathrm{~m}$ and the absence of coccoliths above this level in the Kellogg section coincide with a decline in silicoflagellate abundance and probably a decline in fertility. The richest assemblages from 4 to $12 \mathrm{~m}$ are comparable to the South Atlantic late middle Eocene CP14a Subzone of coccoliths at DSDP Site 356, where associated silicoflagellate assemblages also are similar (Bukry 1977). A similarity in assemblages between DSDP Sites 356 and 208 was implied through the diatom Rylandsia biradiata Greville which occurs at both sites in the coccolith Chiasmolithus gigas Subzone (CP13b). Joint coccolith and diatom correlations between land and deep-sea sites are discussed in the section on diatoms.

The Kellogg Shale was assigned to the middle Eocene Chiphragmalithus quadratus zone of Hay et al. (1967) by Almgren and McDougall (1975), but only a limited number of samples were used for that study and the single list of most common species represented the samples from three localities. Because the essentially noncoeval species Chiasmolithus gigas (Bramlette \& Sullivan) and Reticulofenestra umbilica (Levin) appear in that composite list, strata of slightly different age were combined or similar Coccolithus staurion Bramlette \& Sullivan may have been recorded as Chiasmolithus gigas. Our study of more numerous samples from the Camino Diablo Road section shows that the Kellogg Shale at Byron contains Nannotetrina quadrata Zone, Coccolithus staurion Subzone (CP13b) only in the basal $3 \mathrm{~m}$; the upper $10 \mathrm{~m}$ of coc- 
TABLE 3

Checklist of planktonic foraminifers in CD-sample collection from Kellogg Shale outcrop on Camino Diablo Road, west of Byron, California. Samples CD 16-23 were studied but proved to be barren. Other interspersed barren samples are shown with no occurrences in the table. $\mathrm{A}=$ abundant; $\mathrm{C}=$ common; $\mathrm{F}=$ few; $\mathrm{S}=$ sparse; $\sim=$ related form.

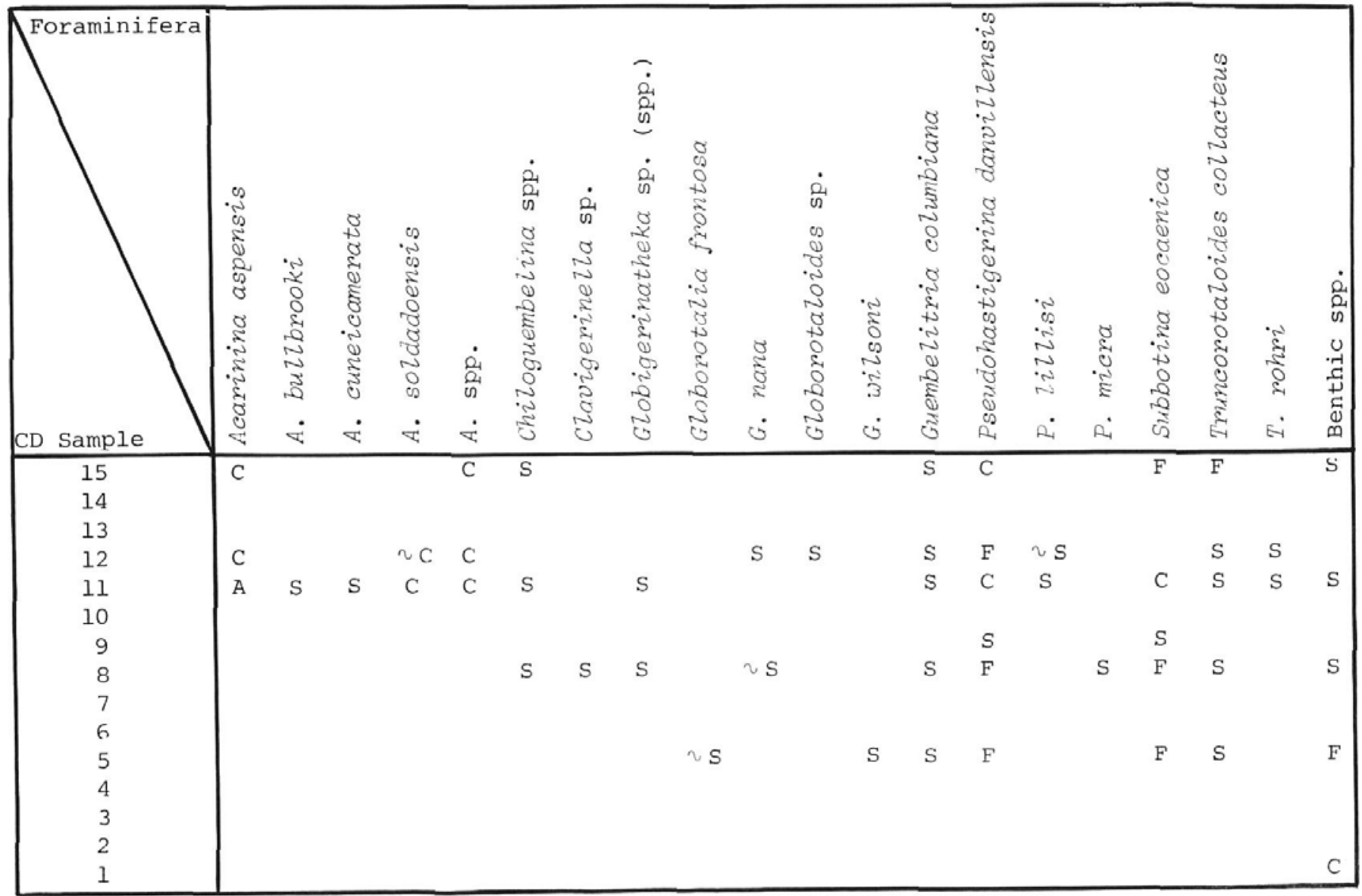

colith-bearing strata contains younger assemblages of the late middle Eocene Discoaster bifax Subzone (CP14a), lacking the older guide taxa $C$. gigas and Nannotetrina quadrata (Bramlette \& Sullivan).

\section{Foraminifers}

Occurrences and estimated abundances of planktonic foraminifer taxa as well as the estimated abundance of benthic foraminifers found in CD samples are tabulated in table 3. The table shows that foraminifers occur sporadically throughout the lower half of the section but are absent in the upper half of the section. The results of this study compare well with the work of Schmidt (1970); most differences are explained by taxonomic considerations.

The occurrence of Pseudohastigerina danvillensis (Howe \& Wallace) with Guembelitria columbiana Howe in the interval between samples CD-5 and CD-15 establishes a middle Eocene age for at least the lower part of the section. Assignment to a specific standard low-latitude zone is difficult, however, because primary and second- ary zone markers are absent from the assemblages. The presence of Acarinina aspensis (Colom) up to sample CD-15 suggests that the lower half of the section falls within the interval of the Hantkenina aragonensis Zone to the Globorotalia lehneri Zone of Stainforth et al. (1975). Inasmuch as coccoliths place the Kellogg section in the Coccolithus staurion Subzone (CP13c) and the Discoaster bifax Subzone (CP14a), correlation with the G. lehneri Zone is favored.

Benthic foraminifers are few to absent in the Kellogg Shale (table 3). We suggest that the paucity of benthic foraminifers is caused by a combination of masking by the siliceous components and the presence of low oxygen levels in bottom waters. The occurrence of fine laminations throughout the section indicates a lack of burrowing activity and supports the interpretation of low oxygen conditions on the sea bed. Previous biostratigraphic studies, which are summarized in Almgren and McDougall (1975), show that the Kellogg Shale is referable to the Amphimorphina jenkensi Zone of the provincial Narizian Stage of California. 
TABLE 4

Occurrence (percent) of planktonic diatoms in CD-sample collection from Kellogg Shale outcrop on Camino Diablo Road, west of Byron, California. Percentage values determined from counts of 300 specimens except for sample CD-10 where values in parentheses represent actual number of specimens counted. $x=$ less than $1 \%$.

\begin{tabular}{|c|c|c|c|c|c|c|c|c|c|c|c|c|c|c|c|c|c|c|c|c|c|}
\hline Sample CD\# & 23 & 22 & 21 & 20 & 19 & 18 & 17 & 16 & 15 & 14 & 13 & 12 & 11 & 10 & 8 & 7 & 6 & 5 & 4 & 3 & 2 \\
\hline Actinoptychus undulatus & $x$ & - & $\mathrm{x}$ & 2 & 1 & 2 & $x$ & $x$ & 2 & 4 & - & 3 & 2 & - & 3 & - & - & $\mathrm{x}$ & $x$ & 1 & - \\
\hline Asterolampra insignis & - & - & - & - & - & - & - & - & $\mathrm{x}$ & - & - & - & - & - & - & - & - & - & - & - & - \\
\hline Chaetoceros spines & 1 & 3 & 3 & 3 & 8 & 2 & 4 & 2 & 6 & $x$ & 10 & 2 & 7 & (2) & 1 & 12 & 9 & 6 & 11 & 15 & 5 \\
\hline Coscinodiscus bultiens & - & - & - & - & - & - & - & - & - & - & - & - & - & - & - & $x$ & 5 & $x$ & - & - & 1 \\
\hline c. marginatus & 1 & 3 & $x$ & - & 2 & 5 & $x$ & $\mathrm{x}$ & 1 & - & 8 & 1 & 1 & - & - & 2 & 3 & 2 & $x$ & $x$ & - \\
\hline C. radiatus & - & 1 & $x$ & - & - & $\mathrm{x}$ & 1 & $x$ & $x$ & 1 & 1 & 1 & $x$ & - & 3 & $x$ & 12 & - & - & 1 & - \\
\hline C. symbolophomes & - & - & - & - & - & - & $x$ & - & - & $x$ & - & - & - & - & $x$ & - & - & - & $x$ & $x$ & - \\
\hline c. tuberculatus var. atlantica & - & - & 2 & 1 & - & - & $x$ & 12 & 6 & 13 & $x$ & $x$ & 8 & - & - & - & - & 2 & $x$ & - & - \\
\hline C. spp. & $x$ & - & - & - & $x$ & - & $x$ & - & $x$ & - & - & - & - & - & - & - & - & - & - & - & - \\
\hline Craspedodiscus oblongus & 4 & 3 & - & - & - & - & $x$ & - & 3 & - & 1 & 4 & 1 & $(3)$ & $x$ & - & 2 & - & $x$ & - & - \\
\hline Cymatosira spp. & - & - & - & - & - & - & 1 & $x$ & - & - & - & - & - & - & - & - & - & - & - & - & - \\
\hline Hantzschia so. & - & - & - & - & - & - & - & - & - & - & - & - & - & - & - & - & - & - & - & - & 10 \\
\hline \multicolumn{22}{|l|}{ Hemiaulus polycyctinomm } \\
\hline var. mesolepta & 2 & 1 & 3 & 8 & 2 & 5 & 4 & 6 & 8 & 16 & 4 & 27 & 7 & (2) & 21 & 1 & 3 & 5 & 3 & 1 & 2 \\
\hline H. spp. & - & - & $x$ & $\mathrm{x}$ & - & - & - & - & - & - & - & - & - & - & - & - & - & - & - & - & - \\
\hline Macrora barbadiensis & - & - & - & - & $x$ & 5 & - & - & - & - & - & - & - & - & 2 & - & - & - & - & - & 1 \\
\hline Melosira architecturalis & $x$ & 4 & 4 & 5 & 13 & 7 & 5 & 5 & 2 & 2 & 2 & $\mathrm{x}$ & 3 & - & 2 & 7 & 3 & 40 & 28 & 20 & 16 \\
\hline M. sulcata & 2 & 2 & 3 & 3 & 1 & 3 & 5 & 1 & $x$ & 1 & $\mathrm{x}$ & $\mathrm{x}$ & $x$ & - & 2 & $x$ & $x$ & 1 & 1 & $x$ & $x$ \\
\hline Monobrachia simplex & - & - & - & - & - & - & - & 2 & - & 2 & $x$ & $x$ & $x$ & - & $x$ & - & - & $\mathrm{x}$ & - & - & - \\
\hline Pseudopodosira bella & - & - & i & 5 & 2 & $x$ & 7 & 4 & $x$ & 6 & 2 & - & $x$ & - & $\mathrm{x}$ & $x$ & 1 & 2 & 2 & $x$ & 3 \\
\hline Pterotheca aculeifera & - & $x$ & 2 & 2 & 6 & 3 & 6 & 1 & 3 & $x$ & 4 & $\mathrm{x}$ & 2 & (1) & $\mathrm{x}$ & $\mathrm{x}$ & $x$ & $\mathrm{x}$ & 3 & $x$ & $x$ \\
\hline P. danica & $\mathrm{x}$ & - & - & - & - & $\mathrm{x}$ & $x$ & $\mathrm{x}$ & - & - & - & - & - & (1) & - & - & - & - & - & - & 1 \\
\hline P. gracillima & - & - & - & $x$ & - & 1 & 2 & $x$ & $x$ & $x$ & - & - & $x$ & - & 2 & - & - & - & - & - & - \\
\hline P. SD. & $x$ & 1 & 1 & $x$ & 1 & 1 & 1 & - & $x$ & $x$ & 3 & - & $\mathrm{x}$ & - & $\mathrm{x}$ & - & - & 1 & 1 & - & $x$ \\
\hline Pyxilla gracilis & 1 & $x$ & 1 & - & 2 & 2 & 1 & $x$ & 1 & - & 5 & 1 & 1 & - & 1 & 2 & 1 & $\mathrm{x}$ & - & - & $\mathrm{x}$ \\
\hline P. intermedia & - & - & $x$ & $x$ & $x$ & $x$ & - & - & 1 & $x$ & $x$ & - & 1 & - & $x$ & - & $\mathrm{x}$ & - & - & - & - \\
\hline \multicolumn{22}{|l|}{ Rhizosolenia hebetata } \\
\hline f. semispina & $x$ & $x$ & 1 & 2 & $x$ & 1 & 1 & 3 & 1 & $x$ & 2 & $x$ & - & (1) & - & $\mathrm{x}$ & $x$ & - & $x$ & - & $\mathrm{x}$ \\
\hline R. sp. 1 & - & - & - & - & - & 2 & - & - & - & - & - & - & - & - & 2 & - & - & - & - & - & - \\
\hline P. SDp. & - & $\mathrm{x}$ & - & 1 & - & - & - & - & - & - & $\mathrm{x}$ & $x$ & $x$ & - & - & - & - & - & - & - & - \\
\hline Riedelia claviger & 11 & 9 & 9 & 4 & 3 & 9 & 11 & 26 & 15 & 18 & 11 & 11 & 10 & (3) & 4 & 8 & 15 & 4 & 11 & 13 & 18 \\
\hline R. sp. 1 & 10 & 2 & 5 & 1 & 1 & 2 & 6 & 1 & 2 & $x$ & 2 & 5 & $x$ & (1) & 3 & 3 & 2 & 4 & 8 & 2 & 1 \\
\hline Sceptroneis spp. & - & - & 1 & 3 & - & 7 & 4 & 3 & 7 & 6 & - & 3 & 2 & - & 3 & $x$ & $x$ & $x$ & $x$ & - & - \\
\hline Stephanopyxis gmunowit & - & - & - & - & - & - & - & - & - & - & - & - & - & - & - & - & - & $x$ & - & $x$ & - \\
\hline S. turris & 3 & 1 & 4 & 5 & 2 & 2 & 5 & 2 & 3 & $\mathrm{x}$ & 2 & 1 & 1 & $(2)$ & - & $x$ & 1 & 1 & $\mathrm{x}$ & 1 & 2 \\
\hline Stictodiscus kittonianus & $x$ & - & - & 1 & - & - & - & - & - & - & - & - & - & - & $x$ & - & - & - & - & - & - \\
\hline Thalassiosira s. 1 & - & - & - & - & - & - & 1 & $x$ & $x$ & - & - & $x$ & $x$ & - & 1 & - & - & - & - & - & - \\
\hline T. $\mathrm{sp} .2$ & - & - & - & - & - & $x$ & $x$ & - & - & 1 & - & - & - & - & $\mathrm{x}$ & - & - & - & $x$ & - & - \\
\hline T. Sp̣. & - & - & - & - & - & $x$ & $x$ & $x$ & - & 2 & - & 2 & - & - & 1 & - & - & $\mathrm{x}$ & $\mathrm{x}$ & - & - \\
\hline Triceratizm barbadense & 3 & - & $\mathrm{x}$ & $x$ & 3 & $\mathrm{x}$ & - & - & - & - & - & - & - & - & $x$ & 3 & 3 & $x$ & 1 & - & 3 \\
\hline T. brachiatum & - & - & - & - & - & - & - & - & - & - & - & - & - & - & - & - & $\mathrm{x}$ & - & - & - & - \\
\hline T. inconspicurm & $\mathrm{x}$ & - & $x$ & 33 & - & - & 19 & - & 4 & $x$ & - & 16 & - & - & - & - & - & - & - & - & $\mathrm{x}$ \\
\hline T. inconspicuum var. trilobata & 59 & 68 & 57 & 18 & 50 & 39 & 8 & 26 & 32 & 21 & 37 & 17 & 45 & (2) & 43 & 57 & 23 & 26 & 23 & 21 & 31 \\
\hline T. kanayae & $\mathrm{x}$ & - & $x$ & - & $x$ & $x$ & $x$ & $x$ & - & - & $x$ & $x$ & - & - & - & 2 & 15 & 2 & 4 & 21 & 3 \\
\hline T. sp. 3 of Schrader \& Fenner (1976) & - & - & - & - & - & - & - & - & - & - & - & - & $x$ & - & $x$ & - & - & $\mathrm{x}$ & - & - & - \\
\hline BENTHIC DIATOMS & - & - & - & $x$ & - & - & 1 & $x$ & 1 & $x$ & - & 1 & 1 & - & $\mathrm{x}$ & - & - & - & - & $\mathrm{x}$ & $x$ \\
\hline
\end{tabular}




\section{Diatoms}

A reconnaissance study of the diatoms of the "O" and " $K$ " series samples was made, and quantitative studies of the diatoms of the "CD" series samples were completed (table 4). Diatoms are abundant and well to moderately well preserved throughout the Kellogg section with the exception of sample CD-9 which is barren of diatoms and sample CD-10 which contains only sparse, poorly preserved diatoms.

Of the diatoms tabulated, 14 forms were not recorded by Kanaya (1957). Many of these forms are small (Cymatosira spp., Hantzschia sp., Sceptroneis spp., Thalassiosira sp. 1, and Thalassiosira sp. 2) and were not recorded in Kanaya's relatively low power $(450 \times)$ traverses. Chaetoceros spines are not conspicuous and were probably overlooked by Kanaya. Other taxa, including Coscinodiscus symbolophorus Grunow, Monobrachia simplex Schrader, Pyxilla gracilis Tempère \& Forti, Rhizosolenia hebetata f. semispina (Hensen) Gran, Rhizosolenia sp. 1, Riedelia sp. 1, Stictodiscus kittonianus Greville, and Triceratium brachiatum, are either sparse or are easily confused with other Kellogg diatoms.

Resting spores assigned to Xanthiopyxis and Liradiscus were tabulated by Kanaya (1957) but were ignored in the present study. Similarly, Kanaya made a greater effort to separate the various rare species of Coscinodiscus than was made in this study.

Kanaya (1957) recognized two Kellogg assemblages. A lower assemblage was characterized by frequent $(>10 \%)$ occurrences of Triceratium kanayae Fenner $(=T$. sp. a of Kanaya), Melosira architecturalis (= Cyclotella hannae of Kanaya), and Pseudopodosira bella Gleser \& Posnova (= Hercotheca? sp. of Kanaya) and less frequent ( $<10 \%)$ occurrences of Triceratium inconspicuum var. trilobata Fenner ( $=T$. barbadense of Kanaya). Abundant to very abundant $(30-80 \%)$ T. inconspicuum var. trilobata and rare $(<7 \%) T$. kanayae and $P$. bella distinguish the upper Kellogg assemblage of Kanaya.
Kanaya's lower assemblage is recognizable in samples CD-2 through CD-6 wherein Melosira architecturalis is generally frequent ( $>15 \%$ of the assemblage) and comparatively Triceratium kanayae is more frequent $(2 \%$ or more of the assemblage) and $T$. inconspicuum is typically less frequent ( $\leq 30 \%$ of the assemblage) than in the upper parts of the Kellogg section. Samples CD-7 through CD-23, the upper $7 / 8$ of the Kellogg section, are characterized by less common $M$. architecturalis $(<10 \%$, except sample CD-13), sparse $T$. kanayae, and common to abundant (typically $35 \%$, but as high as $68 \%$ ) $T$. inconspicuum and correspond to the upper assemblage of Kanaya (1957). Two samples in this upper interval, CD17 and CD-20, show dominance of quadrate forms of $T$. inconspicuum ( $=T$. inconspicuum var. inconspicuum) over forms with three apices $(=T$. inconspicuum var. trilobata). A third sample, CD-12, contains approximately equal numbers of the two forms, but quadrate forms are sparse to absent in the remaining samples. It is not known at this time what the significance of these shifts in dominance of the two forms of $T$. inconspicuum is.

Fenner's (1977) study of Cores 6 to 9 of DSDP Site 356 $\left(28^{\circ} \mathrm{S}\right)$ on the Rio Grande Rise in the South Atlantic represents the best documented study of middle Eocene diatoms. The presence of Coscinodiscus bulliens Schmidt, Craspedodiscus oblongus (Greville) Grunow, Riedelia claviger (Schmidt) Schrader \& Fenner, Thalassiosira sp. 1 ( $=$ T. eccentrica group of Fenner 1977), and Triceratium kanayae suggests that the Kellogg assemblages correlate best with Cores 7 and 6 of Site 356. Bukry (1977) assigned the former core to the Coccolithus staurion Subzone (CP13c) and the latter to the Discoaster bifax Subzone (CP14a), so this diatom correlation of the Kellogg Shale agrees well with the coccolith correlations which also recognize these two subzones in the Kellogg Shale.

A reconnaissance study of well-dated (by coccoliths) middle and upper Eocene diatomaceous material collected by the Deep Sea Drilling Project from the North

TABLE 5

Occurrence of selected diatom extinctions in Deep Sea Drilling Project sections and correlation with coccolith zonation of Okada and Bukry (1980) (shown in parentheses) Core and section number within DSDP section are indicated. Slash indicates sample interval constraint for extinctions. Kellogg Shale diatom assemblages correlate with interval above extinctions of Triceratium kanayae var. quadrilobata and Coscinodiscus argus var. 1 and below extinction of Craspedodiscus oblongus. ${ }^{*}=$ data from Fenner (1977).

\begin{tabular}{|c|c|c|c|c|c|}
\hline DSDP Holes & North & Atlantic & S. Atlantic & South & Pacific \\
\hline Diatom Extinctions & 108 & 386 & 356 & $206 \mathrm{C}$ & 208 \\
\hline Craspedodiscus oblongus & above 1-1 & $\begin{array}{l}\text { above 14-1 } \\
\text { (CP14a) }\end{array}$ & $\begin{array}{c}\text { above } 6-2 * \\
\text { (CP14a) }\end{array}$ & $\begin{array}{c}17-5 / 18-2 \\
(\text { CP14) }\end{array}$ & $\begin{array}{l}\text { above } 27-3 \\
\text { (CP14) }\end{array}$ \\
\hline $\begin{array}{l}\text { Triceratium kanayae var. } \\
\text { quadrilobata }\end{array}$ & above $1-1$ & not seen & $\begin{array}{l}7-1 / 7-2^{*} \\
\quad(\operatorname{CPl} 3 C)\end{array}$ & below $18-2$ & $\begin{array}{r}27-4 / 27-5 \\
(\mathrm{CP} 13 \mathrm{C})\end{array}$ \\
\hline Coscinodiscus argus var. I & $\begin{array}{l}1-5 / 2-1 \\
(\mathrm{CP} 13 \mathrm{~b}-\mathrm{C})\end{array}$ & $\begin{array}{l}14-6 / 15-2 \\
(\mathrm{CP} 13 \mathrm{~b}-\mathrm{C})\end{array}$ & $\begin{array}{l}7-3 / 7-5 \\
\quad(\mathrm{CP} 13 \mathrm{C})\end{array}$ & below $18-2$ & $\begin{array}{r}27-5 / 28-1 \\
(\mathrm{CP} 13 \mathrm{~b})\end{array}$ \\
\hline
\end{tabular}


TABLE 6

Occurrence (percent) of silicoflagellates in K and CD-sample collections from Kellogg Shale at Camino Diablo Road, Byron, California. $x=$ present in numbers too small for meaningful percent. $\otimes$ = predominant taxon in sparse assemblage. ${ }^{*}=$ presence noted following regular count, during photography. See table 1 for stratigraphic interval of samples.

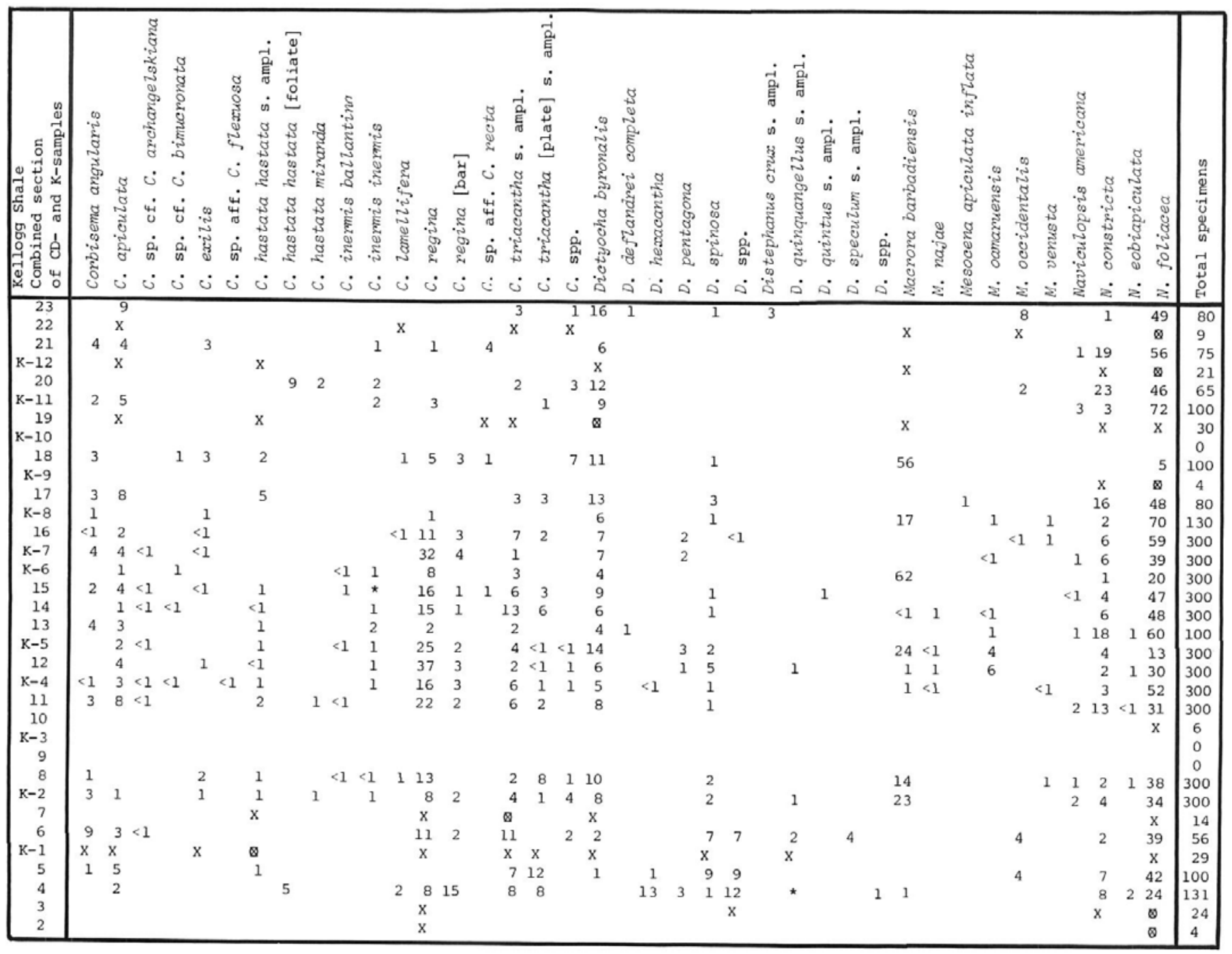

Atlantic (Sites 108, 386, and 402), South Atlantic (Site 356), and South Pacific (Sites 206, 208, and 281) was made in an attempt to further correlate the Kellogg diatom assemblages. Table 5 shows that Triceratium kanayae var. qualilobata Fenner and Coscinodiscus argus var. 1 (pl. 7, fig. 10), which are both lacking from the Kellogg Shale, have fairly consistent last occurrences within or slightly below Subzone CP13c. The last occurrence of Craspedodiscus oblongus appears to be somewhere within the middle or upper part of the Reticulofenestra umbilica Zone (CP14) on the basis of the study of Sites 206, 356 and 386. Cores 3 and 4 of Site 402A, which are equivalent to the Discoaster saipanensis Subzone (CP14b) (assigned to NP17 by Müller 1979), also lack C. oblongus. Well-dated upper Eocene sediments from Sites 281 (Cores 14 to 16) and Site 402A (Core 1) and Schrader's (1978) checklist of the upper Eocene of equatorial
Atlantic Site 366 also indicate that $C$. oblongus does not range above the middle Eocene in contrast to Fenner's (1977) reported range of Eocene to early Oligocene. Fenner (written communication 1983) also acknowledged that C. oblongus does not extend above the middle Eocene. Thus, table 5 indicates that diatom biostratigraphy supports the coccolith correlation of the Kellogg Shale to Subzones CP13c and CP14a.

Table 5 implies that Core 6 of Site 356, Core 27 of Site 208 , and the Kellogg Shale are equivalent in age both by diatoms and coccoliths. Jousé (1979) assigned different ages to each of these units, placing them, respectively, in her middle Eocene Pyxilla gracilis, upper middle Eocene Pyxilla oligocenica-Monobrachia simplex, and lower upper Eocene Hemiaulus polycystinorum-Triceratium barbadense assemblage zones. 


\section{Silicoflagellates}

Like coccoliths, silicoflagellates are most abundant in the middle part of the Kellogg Shale section from 8 to $13 \mathrm{~m}$; however, silicoflagellates range through the entire section (table 6). Although Dictyocha spinosa (Deflandre) Glezer occurs in most samples, the presence of $D$. hexacantha Schulz in two samples near the base of the section indicates a correlation in the Dictyocha hexacantha Zone, which correlates to coccolith subzones CP13c to CP15a. Therefore, the silicoflagellate and coccolith zonations are concordant with previously described DSDP sections (Bukry 1981a). A general absence of $D$. hex acantha through the section, however, contrasts with the persistent occurrence of $D$. spinosa and suggests that differential ecology may have delayed the establishment of even relatively cosmopolitan species. Biostratigraphically, this could confuse correlation for individual samples, such as CD-17 which contains $3 \% D$. spinosa and no younger guides $-D$. hexacantha, Macrora barbadiensis, and Mesocena oamaruensis Schulz. Many Kellogg samples do contain these auxiliary stratigraphic guides, so the seemingly sporadic early occurrences of $D$. hexacantha here and at DSDP Sites 356 and 384 in the Atlantic can be explained.

Kellogg specimens of Macrora najae Bukry and Mesocena venusta Bukry are the first reported from the Pacific basin. Both were originally described from the middle Eocene strata of Site 356 from the South Atlantic, and subsequently from the same age strata in the North Atlantic DSDP Site 386 (Bukry 1977, 1978a).

Two sets of samples (the "CD" and the "K" series) collected from the Kellogg Shale can be best correlated in the samples that were taken 8 to $11 \mathrm{~m}$ above the contact with the underlying Domengine Sandstone. The only occurrences of Macrora najae in the Kellogg section are limited to the 8- to 11-m level, two samples from each sample set. The only abundant occurrences of Mesocena oamaruensis are also limited to one sample from each set within that interval. But the upper and lower samples from the 0- to 8-m and 11- to 23-m intervals show less diagnostic correlation of species abundances and ranges between the two sample sets, which is partly attributable to the greater rarity of silicoflagellates in those intervals. Ecologic and preservational variation of the silicoflagellate assemblages appear to occur at higher frequency than the $0.5-$ to $1.0-\mathrm{m}$ sample interval that was studied.

\section{PALEOECOLOGY}

Silicoflagellates

The diversity of the silicoflagellate assemblages from the Kellogg Shale is slightly greater than other recorded assemblages of the lower Dictyocha hexacantha Zone. However, the generally conservative range of pheno-
TABLE 7

Silicoflagellate genera (average percent if several samples were counted) at localities from different latitudes aid in paleoecologic interpretation of lower Dictyo. cha hexacantha Zone assemblages of the upper middle Eocene. Original quantitative data are from Bukry and Foster (1974) and Bukry (1975, 1976b, 1977. 1978a). Generic code: 1, Corbisema; 2, Dictyocha; 3, Distephanus, 4, Macrora; 5. Mesocena; 6, Naviculopsis.

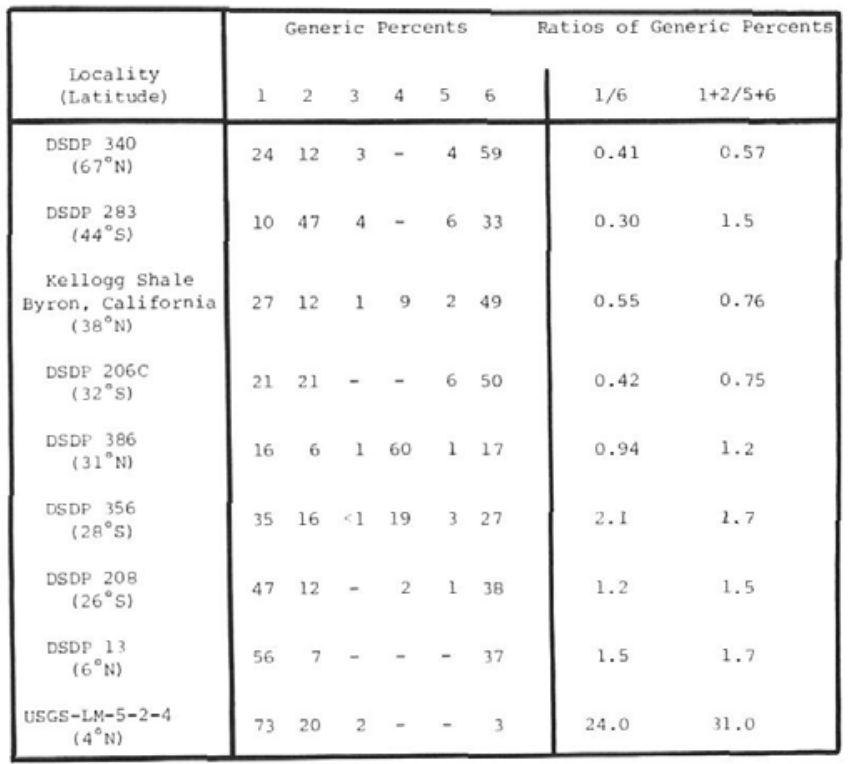

types for the species and the sparseness of irregularly formed skeletons suggests normal marine conditions with moderate upwelling.

Silicoflagellate abundance is greatest in the middle of the section from samples $\mathrm{K}-2$ to $\mathrm{CD}-16$ (4.3 to $13.2 \mathrm{~m}$ ). Both the lower and upper parts of the section have notably. fewer silicoflagellates. The upper section is further distinguished by the decreased occurrence of Corbisema. Changes in water-mass fertility or differential solution of skeletons could have contributed to this reduction because calcareous coccoliths vanish also in the upper part of the section. But a comparison to coeval populations from different latitudes suggests that Corbisema is less abundant at higher latitudes (cooler) where Naviculopsis shows increased abundance relative to lower latitudes (warmer). Admittedly, this comparison is tenuous because of the small numbers of sites and samples that have been enumerated for Eocene silicoflagellates (table 7).

A relative paleotemperature value appears to be best represented in the ratio between percentages of Corbisema and Naviculopsis because of north to south abundance changes in these genera through the latitudinal array of available reference localities (table 7). If this same general ratio is applied to the detailed fluctuation in assemblages through the Kellogg section of California, then a trend (with only four anomalies) shows highest values in the lower part, decreasing to lowest values in the up- 
TABLE 8

Silicoflagellate genera (percent) in Kellogg Shale samples can be compared as ratios to suggest paleoenvironmental fluctuations. Lower ratio values may represent cooler conditions and higher values warmer, on the basis of comparing abundances of genera in coeval strata from different latitudes. Generally lower ratio values above sample 16 (unlettered samples are from the CD-collection) indicate a reduction of Corbisema, presumably resulting from cooler conditions than in the lower section. Generic code: 1, Corbisema; 2, Dictyocha; 3, Distephanus, 4, Macrora; 5, Mesocena; 6, Naviculopsis.

\begin{tabular}{|c|c|c|c|c|c|c|c|c|}
\hline \multirow[b]{2}{*}{$\begin{array}{l}\text { Genera } \\
\text { Samples }\end{array}$} & \multicolumn{6}{|c|}{ Generic Percents } & \multicolumn{2}{|c|}{ Ratios of Generic Percents } \\
\hline & 1 & 2 & 3 & 4 & 5 & 6 & $1 / 6$ & $1+2 / 5+6$ \\
\hline 23 & 13 & 18 & 3 & - & 8 & 50 & 0.26 & 0.53 \\
\hline 22 & - & - & - & - & - & - & - & - \\
\hline 21 & 17 & 6 & - & - & - & 76 & 0.22 & 0.30 \\
\hline $\mathrm{K}-12$ & - & - & - & - & - & - & - & - \\
\hline 20 & 18 & 12 & - & - & 2 & 69 & 0.26 & 0.42 \\
\hline$k-11$ & 13 & 9 & - & - & - & 78 & 0.17 & 0.28 \\
\hline 19 & - & - & - & - & - & - & - & - \\
\hline$K-10$ & - & - & - & - & - & - & - & - \\
\hline 18 & 26 & 12 & - & 56 & - & 5 & 5.2 & 7.6 \\
\hline$\kappa-9$ & - & - & - & - & - & - & - & - \\
\hline 17 & 22 & 16 & - & - & 1 & 64 & 0.34 & 0.58 \\
\hline$K-8$ & 3 & 7 & - & 17 & 2 & 72 & 0.04 & 0.14 \\
\hline 16 & 26 & 9 & - & - & 1 & 65 & 0.40 & 0.53 \\
\hline $\mathrm{K}-7$ & 46 & 9 & - & - & - & 46 & 1.0 & 1.2 \\
\hline$K-6$ & 14 & 4 & - & 62 & - & 21 & 0.67 & 0.86 \\
\hline 15 & 36 & 10 & 1 & - & - & 51 & 0.71 & 0.90 \\
\hline 14 & 38 & 7 & - & 1 & - & 54 & 0.70 & 0.83 \\
\hline 13 & 14 & 5 & - & - & 1 & 80 & 0.18 & 0.23 \\
\hline$K-5$ & 36 & 19 & - & 24 & 4 & 17 & 2.1 & 2.6 \\
\hline 12 & 50 & 12 & 1 & 2 & 6 & 33 & 1.5 & 1.6 \\
\hline $\mathrm{K}-4$ & 33 & 6 & - & 1 & - & 55 & 0.60 & 0.71 \\
\hline 11 & 47 & 9 & - & - & - & 46 & 1.0 & 1.2 \\
\hline 10 & - & - & - & - & - & - & - & - \\
\hline $\mathrm{k}-3$ & - & - & - & - & - & - & - & - \\
\hline 9 & - & - & - & - & - & - & - & - \\
\hline 8 & 30 & 12 & - & 14 & 1 & 42 & 0.71 & 0.98 \\
\hline $\mathrm{K}-2$ & 27 & 10 & 1 & 23 & - & 40 & 0.68 & 0.93 \\
\hline 7 & - & - & - & - & - & - & - & - \\
\hline 6 & 38 & 16 & 6 & - & 4 & 41 & 0.93 & 1.2 \\
\hline $\mathrm{K}-1$ & - & - & - & - & - & - & - & - \\
\hline 5 & 26 & 20 & - & - & 4 & 49 & 0.53 & 0.87 \\
\hline 4 & 48 & 29 & 1 & 1 & - & 34 & 1.4 & 2.3 \\
\hline 3 & - & - & - & - & - & - & - & - \\
\hline 2 & - & - & - & - & - & - & - & - \\
\hline
\end{tabular}

per part. If dissolution has not differentially removed more Corbisema than Naviculopsis, then the latitudinal temperature premise (table 8 ) indicates minor relative cooling through the time of Kellogg deposition.

The only other substantial body of quantitative Eocene data for California silicoflagellates is from the Kreyenhagen Formation, about $200 \mathrm{~km}$ to the south (Dumoulin 1979), which encompasses slightly younger strata from the upper Dictyocha hexacantha Zone. Calculation of generic ratios from Dumoulin's Kreyenhagen species data (tables 9 and 10) shows slightly higher values, signifying warmer oceanic conditions following Kellogg deposition.

The main problems with the generic ratio are large amplitude changes from sample to sample within a section and the selection of coeval stratigraphic levels for comparison. Paleoenvironmental inferences are still preliminary because of the sparsity of comparative data. For example, a three-sample, high-latitude reference at DSDP Site $339\left(67^{\circ} \mathrm{N}\right)$ does not support the trend between Corbisema and Naviculopsis that is observed in lower lati-
TABLE 9

Silicoflagellate genera (percent) at the central California Southeast Monocline Ridge (SMR) locality of the Kreyenhagen Formation (based on data by Dumoulin 1979 ) in upper Dictyocha hexacantha Zone. Generic code: 1, Corbisema; 2, Dictyocha; 3, Distephanus; 4, Macrora; 5, Mesocena; 6, Naviculopsis

\begin{tabular}{|l|cccccc|cc|}
\hline \multicolumn{7}{|c|}{ Generic Percents } \\
SMR Genera & 1 & 2 & 3 & 4 & 5 & 6 & $1 / 6$ & $1+2 / 5+6$ \\
Samples & & & & & & & & \\
\hline 7 & 45 & 11 & 9 & - & 5 & 30 & 1.5 & 1.6 \\
8 & 33 & 28 & 5 & - & 5 & 29 & 1.1 & 1.8 \\
9 & - & - & - & - & - & - & - & - \\
10 & 54 & 15 & 6 & - & 1 & 24 & 2.3 & 2.8 \\
12 & - & - & - & - & - & - & - & - \\
13 & 14 & 45 & 5 & - & 2 & 34 & 0.41 & 1.6 \\
14 & 18 & 24 & 6 & - & 6 & 46 & 0.39 & 0.81 \\
15 & 17 & 36 & 5 & - & - & 42 & 0.40 & 1.3 \\
16 & 7 & 36 & 14 & - & 2 & 41 & 0.17 & 1.0 \\
18 & - & - & - & - & - & - & - & - \\
19 & 7 & 17 & 2 & - & 8 & 67 & 0.10 & 0.32 \\
20 & 10 & 42 & 2 & - & 6 & 40 & 0.25 & 1.1 \\
21 & 11 & 18 & - & - & 4 & 67 & 0.16 & 0.41 \\
22 & 50 & 25 & 7 & - & 1 & 16 & 3.1 & 4.4 \\
23 & 24 & 45 & 3 & - & 11 & 18 & 1.3 & 2.4 \\
24 & - & - & - & - & - & - & - & - \\
25 & 32 & 48 & - & - & 8 & 12 & 2.7 & 4.0 \\
26 & - & - & - & - & - & - & - & - \\
27 & - & - & - & - & - & - & - & - \\
28 & 28 & 11 & 14 & - & 12 & 35 & 0.80 & 0.83 \\
29 & 31 & 2 & 17 & - & 4 & 45 & 0.69 & 0.69 \\
30 & 40 & 7 & 8 & - & 5 & 41 & 0.98 & 1.0 \\
31 & 48 & 10 & 10 & - & - & 32 & 1.5 & 1.8 \\
32 & 18 & 55 & 6 & - & 3 & 18 & 1.0 & 3.5 \\
33 & 33 & 17 & 6 & - & 14 & 30 & 1.1 & 1.1 \\
34 & 29 & 49 & 5 & - & 1 & 16 & 1.8 & 4.6 \\
35 & 26 & 44 & 12 & - & 6 & 12 & 2.2 & 3.9 \\
\hline
\end{tabular}

tudes, whereas adjacent DSDP Site $340\left(67^{\circ} \mathrm{N}\right)$ does support the ratio with low $\mathrm{C} / \mathrm{N}$ values of less than one. But differences in the silicoflagellate assemblages suggest that the Site 340 section is the older of these two sections and is more comparable to the Kellogg section in age. The abundant presence of specialized species of Naviculopsis different from those of the Kellogg, however, emphasizes that paleoenvironmental interpretations ultimately will require the establishment of individual species ranges. Generic ratios may provide guides for the interim.

\section{Diatoms}

Little is known about the ecology of Eocene diatoms, but some observations using the data can be made. The frequent (10\%) Hantzschia sp. which are confined to basal sample CD-2 (table 4) indicate possible proximity to a brackish or fresh-water source during the initial deposition of the Kellogg section. However, it is possible that these specimens represent modern contaminants, although nearly a foot $(30 \mathrm{~cm})$ of soil and rock was excavated before sample CD-2 was taken. In fact, scarcity of benthic diatoms and the lack of common Stephanopyxis spp. or Melosira sulcata (Ehrenberg) Kützing, indicate that the Kellogg section mainly was deposited away from the Eocene strand line.

Table 5 allows comparison of the Kellogg diatoms with middle-latitude sections of comparable age from the deep 
TABLE 10

Silicoflagellate genera (percent) at several central California localities of the Krey enhagen Formation (based on data by Dumoulin 1979) for the upper Dictyocha hexacantha Zone. Sample designations are Tumey Hills Quarry (THQ). Holotype Canyon (HC), Salt Creek (SC), and Oil Canyon (OC). Generic code: 1, Corbisema; 2. Dictyocha; 3, Distephanus; 4, Macrora; 5, Mesocena; 6, Naviculopsis

\begin{tabular}{|c|c|c|c|c|c|c|c|c|}
\hline \multirow[b]{2}{*}{ Genera } & \multicolumn{6}{|c|}{ Generic Percents } & \multicolumn{2}{|c|}{ Ratios of Generic Percents } \\
\hline & 1 & 2 & 3 & 4 & 5 & 6 & $1 / 6$ & $1+2 / 5+6$ \\
\hline THQ 1 & 25 & 54 & 2 & - & 3 & 17 & 1.5 & 4.0 \\
\hline THQ 2 & 38 & 17 & 10 & - & - & 35 & 1.1 & 1.6 \\
\hline THQ 3 & 40 & 27 & 5 & - & 2 & 26 & 1.5 & 2.4 \\
\hline THQ 4 & 24 & 18 & 34 & - & 2 & 18 & 1.3 & 2.1 \\
\hline THQ 6 & 16 & 36 & 4 & - & 17 & 27 & 0.59 & 1.2 \\
\hline THQ 7 & 25 & 32 & 2 & - & 17 & 24 & 1.0 & 1.4 \\
\hline THQ 10 & 28 & 22 & 10 & - & 17 & 24 & 1.2 & 1.2 \\
\hline THQ 11 & 56 & 21 & 1 & - & 16 & 6 & 9.3 & 3.5 \\
\hline $\mathrm{HC} 1$ & 51 & 20 & 11 & - & 3 & 15 & 3.4 & 3.9 \\
\hline $\mathrm{HC} 3$ & 45 & 23 & 2 & - & 5 & 25 & 1.8 & 2.3 \\
\hline HC 4 & 31 & 38 & 2 & - & 5 & 24 & 1.3 & 2.4 \\
\hline HC 5 & 40 & 18 & 3 & - & 3 & 36 & 1.1 & 1.5 \\
\hline HC 7 & 28 & 22 & 3 & - & 5 & 42 & 0.67 & 1.1 \\
\hline HC 9 & 23 & 16 & 1 & - & 15 & 45 & 0.51 & 0.65 \\
\hline HC 10 & 22 & 25 & 2 & - & 25 & 26 & 0.85 & 0.92 \\
\hline SC 1 & 28 & 23 & - & - & 2 & 47 & 0.60 & 1.0 \\
\hline sc 6 & 26 & 18 & - & - & 13 & 43 & 0.60 & 0.79 \\
\hline sc 7 & 32 & 24 & 1 & - & 16 & 27 & 1.2 & 1.3 \\
\hline SC 8 & 18 & 53 & 8 & - & 3 & 17 & 1.1 & 3.6 \\
\hline SC 9 & 35 & 22 & - & - & - & 44 & 0.80 & 1.3 \\
\hline SC 12 & 28 & 51 & - & - & 6 & 15 & 1.9 & 3.8 \\
\hline SC 14 & 8 & 63 & - & - & 14 & 15 & 0.53 & $\begin{array}{l}2.4 \\
1.2\end{array}$ \\
\hline SC 15 & 30 & 24 & 2 & - & 6 & 38 & 0.79 & 1.2 \\
\hline OC 14 & 25 & 27 & 3 & - & 16 & 29 & 0.86 & 1.2 \\
\hline
\end{tabular}

sea. Quantitative studies of the diatoms of five samples from DSDP Site 356 in the South Atlantic, four from DSDP Site 386 in the North Atlantic, and three from DSDP Sites 206 and 208 in the South Pacific yield the results shown on table 11. An average of the 20 "CD" samples from the Kellogg shale which contain common diatoms is shown for comparison. Surprisingly, virtually all the DSDP samples contain common to abundant Melosira sulcata (Ehrenberg) Kützing, a form which is concentrated on the shelf in modern oceans. On the other hand, $M$. sulcata is relatively rare ( $2 \%$ average) in the Kellogg section. While it is possible that $M$. sulcata possessed different ecological affinities in the Eocene, it is more likely that this heavily silicified, solution-resistant diatom is concentrated by dissolution of more fragile forms and/or by bottom currents that may have concentrated them during deposition.

The abundant Triceratium inconspicuum in the Kellogg section (tabulated with $T$. barbadense Greville in table 11) compares best with the $20 \%$ values for these taxa found in sample 27-3 of DSDP Site 208, but on the whole, it contrasts markedly with the sparse to few $T$. inconspicuum and T. barbadense typical of the DSDP middlelatitude samples. As silicoflagellates suggest that Cores 2 to 11 of DSDP Site 340 in the Norwegian Sea are coeval with the Kellogg section, Schrader and Fenner's (1976) checklist of the diatoms of Site 340 can also be compared to the quantitative Kellogg diatom data. Schrader
TABLE 11

Percentage comparison of major diatom species groups from Kellogg Shale samples and samples of an equivalent age from various DSDP sections (see table 5). Core and section numbers are given for the DSDP sections. Tk = Triceratium kanayae, $\mathrm{Ti}+\mathrm{Tb}=T$. inconspicuum plus $\mathrm{T}$. barbadense, $\mathrm{Ma}=$ Melosira architecturalis, $\mathrm{Pb}=$ Pseudopodosira bella, $\mathrm{Hp}=$ Hemiaulus polycystinorum s. ampl., $\mathrm{Ms}=$ Melosira sulcata, Ried $=$ Riedelia spp. $\mathrm{Cta}=$ Coscinodiscus tuberculatus var. atlantica, Step. $=$ Stephanopyxis spp., Pyx. $=$ Pyxilla spp.

\begin{tabular}{|c|c|c|c|c|c|c|c|c|c|c|c|c|}
\hline \multicolumn{2}{|c|}{ Sample } & TK & $\mathrm{T}+\mathrm{Tb}$ & $\mathrm{Ma}$ & $\mathrm{rb}$ & Hp & Ms & Ried. & Cta & Step. & Pyx. & Other \\
\hline \multirow[t]{5}{*}{$356\left(28^{\circ} \mathrm{s}\right)$} & ) $6-2$ & 0 & 8 & 1 & 6 & 27 & 28 & 10 & 0 & 6 & 5 & 11 \\
\hline & $6 \sim 4$ & 0 & 1 & 3 & 6 & 21 & 43 & 9 & 0 & 6 & 6 & 5 \\
\hline & $6-6$ & 0 & 1 & 3 & 6 & 32 & 35 & 12 & 0 & 1 & 8 & 9 \\
\hline & $7-1$ & 0 & 6 & 2 & 32 & 17 & 19 & 10 & 2 & 3 & 3 & 5 \\
\hline & $7-3$ & 4 & 11 & 9 & 29 & 8 & 9 & 21 & 1 & 2 & 2 & 4 \\
\hline \multirow[t]{4}{*}{$386\left(31^{\circ} \mathrm{k}\right)$} & $14-1$ & 0 & 4 & 6 & 13 & 8 & 63 & 0 & 0 & 2 & 2 & 2 \\
\hline & $14-2$ & 0 & 0 & 2 & 11 & 3 & 71 & 3 & 0 & 3 & 2 & 5 \\
\hline & $14-4$ & 0 & 0 & 6 & 21 & 3 & 60 & 1 & 1 & 1 & 1 & 5 \\
\hline & $14-6$ & 1 & 4 & 8 & 20 & 3 & 53 & 0 & 0 & 3 & 2 & 6 \\
\hline \multirow[t]{2}{*}{$208\left(26^{\circ} \mathrm{S}\right)$} & $27-3$ & 9 & 20 & 0 & 0 & 12 & 21 & 15 & 0 & 9 & 2 & 12 \\
\hline & $27-4$ & 5 & 12 & 6 & 0 & 11 & 22 & 8 & 8 & 18 & 1 & 1 \\
\hline $206 \mathrm{C}\left(32^{\circ} \mathrm{s}\right)$ & $18-2$ & 0 & 1 & 13 & 1 & 11 & 47 & 7 & 0 & 8 & 3 & 9 \\
\hline \multicolumn{2}{|c|}{$\operatorname{Kellogg}\left(38^{\circ} \mathrm{N}\right)$} & 2 & 39 & 8 & 2 & 6 & 2 & 14 & 2 & 2 & 1 & 12 \\
\hline
\end{tabular}

and Fenner (1976) listed Chaetoceros spines, Hemiaulus spp., Stephanopyxis turris (Greville and Arnott) Ralfs, Triceratium barbadense (not distinguished from $T$. inconspicuum), and Trochosira coronata Schrader and Fenner as the dominant diatoms of Site 340. Similarities of this high-latitude $\left(67^{\circ} \mathrm{N}\right)$ site with the Kellogg section $\left(38^{\circ} \mathrm{N}\right)$ in terms of common to abundant Triceratium inconspicuum plus $T$. barbadense possibly reflects the location of the Kellogg site of deposition within the Eocene equivalent of the cool water California Current. The California Current or its analogue has been active since at least the Late Cretaceous (Sliter 1972). Consequently, T. inconspicuum plus $T$. barbadense might be considered a cool-water component.

Table 4 reveals that the abundance of these two Triceratium species is greatest $(>50 \%)$ in the uppermost part of the Kellogg section (samples CD-19 through CD-23) and in sample CD-7 in the lower part of the section. The abundance of these taxa is least $(<35 \%)$ in the lowest part (samples CD-2 through CD-6) and in the middle part (samples CD-12, CD-14, CD-16, and CD-17) of the Kellogg section. Thus, the generalized cooling trend for the Kellogg section inferred from the silicoflagellate data is supported by the diatoms.

Keller and Keigwin (written communication 1982) reported a cooling trend from the Coccolithus staurion Subzone (CP13c) into the Discoaster bifax Subzone (CP14a) based on oxygen isotope and planktonic foraminiferal studies at DSDP Site 363 in the southeast Atlantic. Consequently, the cooling trend within the Kellogg section may be part of a global cooling trend for the $\mathrm{CP} 13 \mathrm{c}-$ CP14a interval.

Sample to sample comparison of the silicoflagellate and diatom relative paleotemperature interpretations show 


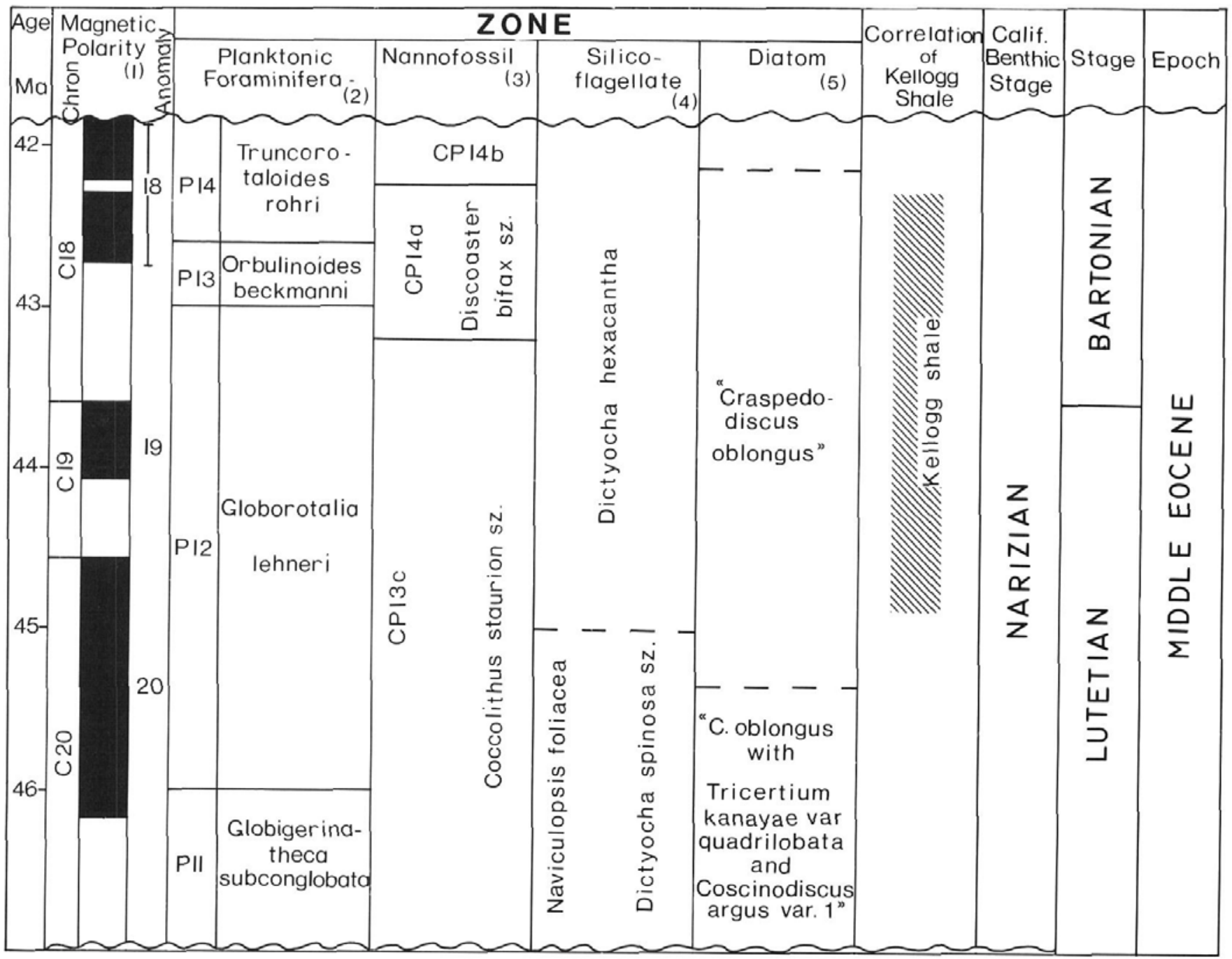

TEXT-FIGURE 2

Correlation between Kellogg Shale and the international geologic time scale of Berggren et al. (in press). Silicoflagellate zones are correlated with coccolith zones after Bukry (1981a). 1 = Berggren et al. (in press); 2 = Blow (1969) and Stainforth et al. (1975); 3 = Bukry (1975) and Okada and Bukry (1980); 4 = Bukry (1981); and 5 = Barron, this report.

less agreement. For example, samples CD-16 and CD-17 contain a supposed relatively warm diatom flora (26 and $27 \%$ respectively of Triceratium barbadense and $T$. inconspicuum) but have low ratios of Corbisema to Naviculopsis ( 0.40 and 0.34 , respectively) which indicate cooler conditions for the silicoflagellates.

\section{PRELIMINARY CORRELATION WITH THE SIDNEY SHALE MEMBER}

The Sidney Shale Member of Clark and Campbell (1942) is exposed about $6 \mathrm{mi}$ from the northernmost exposures of the Kellogg Shale (Kanaya 1957). Like the Kellogg, the Sidney Shale Member is rich in diatoms and radiolarians and contains both planktonic and benthic foraminifers.

Clark and Campbell (1942) reported a marked difference in the composition of the radiolarian faunas of the Kel- logg and Sidney shales-only 31 forms of the 127 they reported were common to both assemblages-and they concluded that the two units represent distinct faunal assemblages.

Kanaya (1957) considered the Kellogg and Sidney diatom assemblages to be coeval, but he noted that Craspedodiscus oblongus was restricted to the Kellogg Shale.

Schmidt (1970) correlated both Kellogg and Sidney planktonic foraminifers to the middle Eocene Truncorotaloides rotundimarginatus Zone and both Kellogg and Sidney coccoliths to the middle Eocene Chiphragmalithus quadratus Zone of Hay et al. (1967).

Almgren and McDougall (1975) reviewed these correlations and benthic foraminiferal studies by Fulmer (1954) 
and concluded that the Kellogg and Sidney are separate exposures of the same unit.

Reconnaissance study of the diatoms from 11 samples collected from Kanaya's (1957) section of the Sidney failed to recover Craspedodiscus oblongus. Indeed, Kanaya (1957) noted only a single specimen of $C$. oblongus from sample LSJU M-610-3 from the middle part of his section. As stated earlier, $C$. oblongus has its last occurrence in late middle Eocene coccolith zone CP14 (Reticulofenestra umbilica Zone). The apparent absence of C. oblongus from the Sidney Shale Member indicates that the Sidney is no older than the latest middle Eocene and is younger than the Kellogg Shale.

\section{SUMMARY}

The Kellogg Shale correlates with the Globorotalia lehneri Zone (planktonic foraminifers) of Stainforth et al. (1975) (= P12 of Blow 1969), the Coccolithus staurion (CP13c) and Discoaster bifax (CP14a) Subzones (coccoliths) of Bukry (1975), the Dictyocha hexacantha Zone (silicoflagellates) of Bukry (1981a), and the diatom interval containing Craspedodiscus oblongus above the last occurrences of Coscinodiscus argus var. 1 and Triceratium kanayae var. quadrilobata. Following the Paleogene time scale of Berggren et al. (in press) and the silicoflagellate zonal correlations of Bukry (1981a), the Kellogg Shale correlates to the middle Eocene, upper paleomagnetic Chron 20 to middle Chron 18, ca. 42-45 Ma, and the upper Lutetian to the lower Bartonian Stage of Europe (text-fig. 2). Earlier benthic foraminiferal studies have placed the Kellogg Shale within the Narizian Benthonic Foraminiferal Stage of Mallory (1959) (Fulmer 1954; Almgren and McDougall 1975). This correlation of the Narizian Stage to the international geologic time scale is consistent with the results of Poore (1976) and Poore and Brabb (1977). The late Eocene age assigned by the USGS Lexicon of Geologic Names of the United States (Keroher et al. 1966) to the Kellogg Shale should be revised to middle Eocene.

Quantitative studies of diatoms and silicoflagellates suggest a general cooling trend through deposition of the Kellogg Shale section. Dissolution of calcareous microfossils (planktonic foraminifers and coccoliths) in the upper part of the section is supportive of this cooling trend. Keller and Keigwin (written communication 1982) reported a cooling trend within age equivalent strata at DSDP Site 363 in the southeast Atlantic, so the cooling trend observed within the Kellogg section may be part of a global cooling trend.

The marine age correlations of standard reference sections onshore can be improved by combining the biostratigraphies of several planktonic microfossil groups which have been effectively applied in deep-sea correlations
(Bronnimann et al. 1971; Milow in Hays et al. 1972; Poore et al. 1981). Integrating land sections like the Kellogg Shale into standard oceanic zonal systems should improve regional biostratigraphy and broaden the data base for global paleoclimatology.

\section{SYSTEMATICS}

Silicoflagellates

Genus CORBISEMA Hanna 1928

Corbisema angularis Bukry, n. sp.

Plate 1, figures 1-8

Description: Corbisema angularis is a medium-sized triangular species with straight sides and moderate spines. The symmetrical ring is equilateral or slightly isosceles and is narrower than the apical struts. There are three distinct pikes at the strut-ring junctions.

Remarks: Corbisema angularis is distinguished from Corbisema recta (Schulz) by having distinct basal pikes, longer spines, relatively narrower ring, and straighter, less convex, sides. Similarly, $C$. angularis is distinguished from Dictyocha trigona Zittel by having basal pikes and relatively narrower sides compared to apical strut width.

Occurrence: Corbisema angularis occurs through the upper middle Eocene Kellogg Shale from 1.5 to $20 \mathrm{~m}$ above the Domengine Sandstone west of Byron, California. This interval is assigned to the lower Dictyocha hexacantha Zone. Corbisema angularis occurs at abundances up to 9\% (aver. 3\%).

Size: Maximum internal diameter of ring 23 to $40 \mu \mathrm{m}$.

Holotype: USNM 347001 (pl. 1, figs. 2, 3).

Isotypes: USNM 347002 to 347007.

Type locality: Kellogg Shale, Camino Diablo Road section, Byron, California, in sample K-11.

Corbisema exilis Bukry, n. sp.

Plate 1, figures 9-12

Description: Corbisema exilis is a medium-sized, slightly isosceles species with short spines and short pikes at the strut-ring junctions. The ring is distinctly narrower than the apical struts. The sides of the ring are convex. Spines are slightly asymmetrical.

Remarks: Corbisema exilis is distinguished from C. bimucronata rotatoria Bukry and $C$. hastata miranda Bukry by the ring being much thinner than the apical struts. The distinct contrast in thickness combined with the ring shape distinguishes $C$. exilis from other species.

Occurrence: Corbisema exilis is sparsely present $(<1$ to $3 \%$ ) between the 4.5- and $20-\mathrm{m}$ sample levels in the Kellogg Shale section west of Byron, California. The assem. 
blages are assigned to the upper middle Eocene and to the Dictyocha hexacantha Zone.

Size: Maximum internal diameter of ring 24 to $29 \mu \mathrm{m}$.

Holotype: USNM 347008 (pl. 1, fig. 9).

Isotypes: USNM 347009 to 347011.

Type locality: Kellogg Shale, Camino Diablo Road section, Byron, California, in sample K-2.

\section{Corbisema hastata miranda Bukry, n. subsp.}

Dictyocha triacantha var. apiculata f. minor SCHULZ 1928 (in part), p 249, fig. 29b (not a).

Corbisema hastata (Lemmermann).-PERCH-NIELSEN 1975 (in part), p. 685 , pl. 3, fig. 2.

Corbisema hastata minor (Schulz).-BUKRY 1975, p. 854, pl. 1, fig. 10.

Description: Corbisema hastata miranda is a small subspecies with moderate to short spines. The apical bars meet at symmetrical angles, but the ring is isosceles. The ring along the two lower portals is distinctly convex on one side and straight on the other. The straight base, inflated sides, and small size are distinctive. Pikes are missing or indistinct.

Remarks: According to Loeblich et al. (1968), the name Dictyocha triacantha var. apiculata f. minor Schulz 1928 is a junior homonym to Dictyocha triacantha f. minor Schulz which appeared earlier in the same paper. This invalidated the name by ICBN Art. 64, par. 4. Therefore, the new subspecies Corbisema hastata miranda is described to validly accommodate the morphologic concept of Dictyocha triacantha var. apiculata f. minor Schulz.

Comparison of the type specimens shows that Corbisema hastata miranda is distinguished from $C$. hastata hastata by having an essentially flat base, distinctly inflated lower portals, symmetrical apical structure, smaller size, and proportionally shorter height. It is distinguished from C. hastata cunicula Bukry (see Bukry 1976a) by shorter spines and symmetrical apical structure.

Size: Internal height 18 to $22 \mu \mathrm{m}$.

Holotype: Plate 1, figure 10 of Bukry 1975.

Type locality: Tasman Sea, DSDP sample 283-6-1, 125 $\mathrm{cm}(124 \mathrm{~m})$.

\section{Corbisema inermis ballantina Bukry, $\mathbf{n}$. subsp.}

Plate 1, figure 13; plate 2, figures 1-3

?Dictyocha triacantha var. inermis Lemmermann.-SCHULZ 1928 (in part), p. 249, fig. 30a.

Corbisema inermis inermis (Lemmermann).-BUKRY 1977, p. 831, pl. 1 , fig. 5 .

Description: Corbisema inermis ballantina is large with a smooth, symmetrical, three-lobed outline. There are no spines; pikes are short and broad, situated at the strutring junction. The portals are broadly rounded, and the widths of the ring and apical struts are the same. The apical structure is arched above the ring.

Remarks: Corbisema inermis ballantina is distinguished from Corbisema inermis inermis (Lemmermann) by a more indented trilobate periphery and shorter pikes. It is distinguished from $C$. ovalis Perch-Nielsen by the absence of spines, more rounded portal apices, and more equal ring and strut widths.

Occurrence: Corbisema inermis ballantina occurs sparsely in the upper middle Eocene Kellogg Shale between sample depths 4.5 to $12.5 \mathrm{~m}$. Percentages are only one or less. It occurs in the middle Eocene of DSDP Site 356 in the South Atlantic.

Size: Maximum internal diameter of ring 55 to $70 \mu \mathrm{m}$.

Holotype: USNM 347012 (pl. 1, fig. 13).

Isotypes: USNM 347013 and 347014.

Type locality: Kellogg Shale, Camino Diablo Road section, Byron, California, in sample CD-15.

Corbisema regina Bukry, n. sp.

Plate 2, figures 5-13

Corbisema triacantha var. minor (Schulz). - LING 1972 (in part), p. 158, pl. 24, figs. 20-23.

Description: Corbisema regina is a triangular species with rounded to blunt apices. Spines are moderate to short and basal pikes at the strut-ring junctions are small. The apical structure has struts expanded into a central plate or flattened struts and expanded center. The ring periphery is slightly indented at the strut junctions.

Remarks: Corbisema regina is distinguished from C. triacantha (Ehrenberg) by having small pikes, indented sides and an apical plate, from $C$. triacantha convexa Bukry by indented instead of convex sides and smaller strut-ring junction structures, from C. lamellifera (Glezer) (pl. 2, fig. 4) by normal tubular spines and apices instead of flattened spines and apices.

Occurrence: Corbisema regina occurs most commonly (up to $37 \%$ ) through the middle part of the Kellogg Shale section and ranges throughout. It is also present in the middle Eocene assemblages at DSDP Site 356 in the South Atlantic (for example, 356-7-1, 130-131 cm).

Size: Maximum internal diameter of ring 20 to $25 \mu \mathrm{m}$.

Holotype: USNM 347015 (pl. 2, fig. 6).

Isotypes: USNM 347016 to 347023.

Type locality: Kellogg Shale, Camino Diablo Road section, Byron, California, in sample CD-8. 
Genus DICTYOCHA Ehrenberg 1837

Dictyocha byronalis Bukry, n. sp.

Plate 3 , figures $1-14$

?Dictyocha fibula Ehr. var. fibula f. fibula GLEZER 1966 (in part), p. 265, pl. 13 , figs. 8,9 ; pl. 14, fig. 4 .

?Dictyocha sp. (asperoid) BUKRY 1977, p. 831, pl. 1, fig. 10

Dictyocha sp. A BUKRY 1978a, p. 785, pl. 2, figs. 4, 5.

Description: Dictyocha byronalis is a moderate- to longspined species with a canted apical bar that is usually oriented subparallel to the short axis of the basal ring. The moderate-sized basal ring is slightly bowed-out at the asymmetrical strut junctions, which can produce a nearly eight-sided periphery. Four distinct basal pikes are well offset from the strut junctions.

Remarks: Dictyocha byronalis is distinguished from Dictyocha aspera (Lemmermann), D. brevispina (Lemmermann), D. pulchella Bukry, and D. fibula var. fibula f. eocaenica Krotov, by the canted alignment of the bar and the bowed-out flexure of the basal ring at and near the strut junctions. It is distinguished from younger $D$. aculeata (Lemmermann) and D. subaculeata (Bukry) by bar alignment, from $D$. clinata Bukry by much larger pikes but smaller ring. The variation in flexure of the ring and variation in spine length are fairly large within and between populations of $D$. byronalis.

Occurrence: Dictyocha bryonalis occurs in the upper middle Eocene Kellogg Shale of California at abundances up to $16 \%$. Other occurrences are the middle Eocene at DSDP Sites 356, 385, and 386 in the Atlantic Ocean.

Size: Maximum internal diameter of ring 22 to $33 \mu \mathrm{m}$; total length 55 to $77 \mu \mathrm{m}$.

Holotype: USNM 347024 (pl. 3, fig. 3).

Isotypes: USNM 347025 to 347037.

Type locality: Kellogg Shale, Camino Diablo Road section, Byron, California, in sample K-6.

\section{Genus NAVICULOPSIS Frenguelli 1940}

Naviculopsis americana Bukry, n. sp.

Plate 4, figures 17-19; plate 5, figures 1-5

Description: Naviculopsis americana has a wide ring with moderate spines and a narrow to moderate apical band. The apices of the ring are fairly angular. The length to width ratio for the ring ranges from 2.4 to 3.0 . Spines are about half the length of the ring. The width of the band is about equal to the tube width.

Remarks: Naviculopsis americana is distinguished from $N$. constricta (Schulz) emend. Bukry by the greater width of the ring relative to spine width and more angular apices. It is distinguished from $N$. minor (Schulz) by larger size and more angular apices. It is distinguished from $\mathrm{N}$. eobiapiculata by having a complete apical band.

Occurrence: Naviculopsis americana is sparse and sporadic in the Kellogg Shale section of Camino Diablo Road, Byron, California. It ranges up to $3 \%$ in abundance in these late middle Eocene samples.

Size: Length 100 to $130 \mu \mathrm{m}$; width 20-25 $\mu \mathrm{m}$.

Holotype: USNM 347038 (pl. 5, fig. 2).

Isotypes: USNM 347039 to 347045.

Type locality: Kellogg Shale, Camino Diablo Road section, Byron, California, in sample CD-11.

Naviculopsis constricta (Schulz) emend. Bukry, n. comb.

Plate 5, figure 6

Dictyocha navicula var. biapiculata fa. constricta n. fa. SCHULZ 1928, p. 246 , fig. 21 [N.B. the incorrect figure caption: D. navicula var. constricta is superseded by the text designation as a new forma.]

Naviculopsis constricta (Schulz).-FRENGUELLI 1940, p. 61, figs. 11a, b. [Frenguelli elevated var. constricta-the erroneous figure caption-instead of the text formation fa. constricta. The new combination proposed here is the elevation of fa. constricta.]

Remarks: It is clear from the text of Schulz (1928, pp. 243-246) that two new forms, fa. aspera and fa. constricta, were designated for Dictyocha navicula var. biapiculata. Unfortunately, the associated figures were miscaptioned as $D$. navicula var. aspera and $D$. navicula var. constricta. Later workers accepted the incorrect caption nomenclature as basionyms, instead of the formal text designations. The elevation of fa. constricta is shown above, and elevation of fa. aspera, as proposed by PerchNielsen (1976), should be the following: Naviculopsis aspera (Schulz), n. comb. Basionym-Dictyocha navicula var. biapiculata fa. aspera Schulz, 1928, p. 246, figs. $20 a, b$.

The combination of short- and long-ringed forms assigned to $N$. constricta by Frenguelli (1940) when naming the genus Naviculopsis and the expansion by Ling (1972) to include the common Eocene forms with moderate length rings and spines are useful. These additions to the original concept of $N$. constricta have been substantiated in DSDP Paleogene assemblages which show that the large and small forms assigned to $\mathrm{N}$. constricta cooccur through the interval. Although smaller forms predominate, the elongate original of $N$. constricta has a similar long range. Therefore, $N$. constricta is emended to include the morphologies of Naviculopsis specimens assigned to N. constricta by Frenguelli (1940), Ling (1972), Perch-Nielsen (1975), Bukry (1976a), and Martini and Muller (1976). This emendation formalizes the actual usage in recent literature.

Naviculopsis americana $\mathrm{n}$. $\mathrm{sp}$. and $\mathrm{N}$. minor are also 
banded, but they can be distinguished from newly emended $N$. constricta by ring morphology.

\section{Naviculopsis minor (Schulz) Bukry, n. comb.}

Dictyocha navicula E var. minor n.v. SCHULZ 1928, p. 246, fig. 22. ?Naviculopsis minor (Schulz). -FRENGUELLI 1940, p. 61, fig. 11i [transfer invalid: no basionym cited]

not Naviculopsis biapiculata (Lemmermann) Frenguelli var. minor (Schulz).-GLEZER 1966, p. 274, pl. 16, figs. 6-8; pl. 17, figs. 1-3, 6. [These lack the requisite rectangular ring.]

Remarks: Distinction of Naviculopsis minor (Schulz) for biostratigraphy was recommended by Katharina PerchNielsen (written communication 1982). If the original morphology that emphasizes a rectangular ring and short spine is adhered to, then $N$. minor appears to be stratigraphically restricted. It is not present in the middle Eocene Kellogg Shale, but is well represented in the lower Eocene of North Atlantic DSDP Hole 553A. Studies of lower Eocene assemblages from northern Europe by Martini $(1974,1981)$ first indicated the biostratigraphic potential of $N$. minor when properly identified.

\section{Coccolithophorids}

Genus HELICOSPHAERA Kamptner 1954

\section{Helicosphaera neolophota Bukry, n. sp.}

Plate 5, figures $10-21$

Description: Helicosphaera neolophota has an entire ovate periphery that is broader and flatter at the end with the flange overlap. An ovate central opening occupies 37 to $67 \%$ (46\% average) of the overall specimen length. A broad bar, which broadens at the ends and may have an axial lineament, makes an angle of 30 to $50^{\circ}$ with the major axis. In cross-polarized light, the bar and rim are bright with the major axis at $0^{\circ}$. The broad end of the rim has no serrate extinction line and is structurally simple.
Remarks: Helicosphaera neolophota is distinguished from H. lophota (Bramlette \& Sullivan) by the lower angle of the smaller bar, the broadened ends of the bar, and the absence of a serrate extinction line in the rim. It is distinguished from $H$. seminulum (Bramlette \& Sullivan) by a larger bar at a higher angle and by a broader ovate outline. Helicosphaera bramlettei Muller lacks an entire margin and has a shorter sigmoid bar, whereas $H$. wilcoxonii has a bar aligned near the minor axis. Helicosphaera neolophota is believed to be a descendant of older $H$. lophota.

Occurrence: Helicosphaera neolophota is sparse to common throughout the Kellogg Shale at Byron, California, occurring in the upper middle Eocene Coccolithus staurion Subzone (CP13c) and Discoaster bifax Subzone (CP14a).

Size: Maximum length 11 to $16 \mu \mathrm{m}$.

Holotype: USNM 347046 (pl. 5, figs. 10-11).

Isotypes: USNM 347047 to 347051

Type locality: Kellogg Shale, Camino Diablo Road section, Byron, California, in sample K-4.

\section{TAXONOMIC NOTES}

(Plate and figure numbers in parentheses refer to present paper. A dash separates species citation from representative illustrations.)

Silicoflagellates

Corbisema apiculata (Lemmermann) Hanna; as Dictyocha triacantha apiculata Lemmermann 1901, p. 259, pl. 10, figs. 19, 20.

C. archangelskiana (Schulz) Frenguelli; as Dictyocha triacantha archangelskiana Schulz 1928, p. 250, figs. 33a-c, 77 (not fig. 78).

C. bimucronata Deflandre 1950, p. 191, figs. 174-177.

C. sp. aff. C. flexuosa (Stradner) Perch-Nielsen 1975, p. 685, pl. 3, fig. 10 ; as $C$. triacantha var. flexuosa Stradner 1961, p. 89 , figs. $1-8$, fig. $1 c$.

C. hastata hastata (Lemmermann) Frenguelli; as Dictyocha triacantha var. hastata Lemmermann 1901, p. 259, pl. 10, figs. 16, 17.

\section{PLATE 1}

Eocene silicoflagellates from the Kellogg Shale

Scale bar for figures $1-12$ equals $10 \mu \mathrm{m}$, for figure 13 it equals $20 \mu \mathrm{m}$

1-8 Corbisema angularis Bukry, n. sp.

1, USNM 347002, sample CD-6; 2-3, holotype, USNM 347001, sample K-11, two focuses; 4, USNM 347003, sample CD-11; 5, USNM 347004, sample CD-8; 6, USNM 347005, sample CD-8; 7, USNM 347006, sample CD-18; 8, USNM 347007, sample CD-8.
9-12 Corbisema exilis Bukry, n. sp.

9, holotype, USNM 347008, sample K-2; 10, USNM 347009, sample K-7; 11, USNM 347010, sample K-2; 12, USNM 347011, sample CD-8.

13 Corbisema inermis ballantina Bukry, $n$. subsp. Holotype, USNM 347012, sample CD-15. 


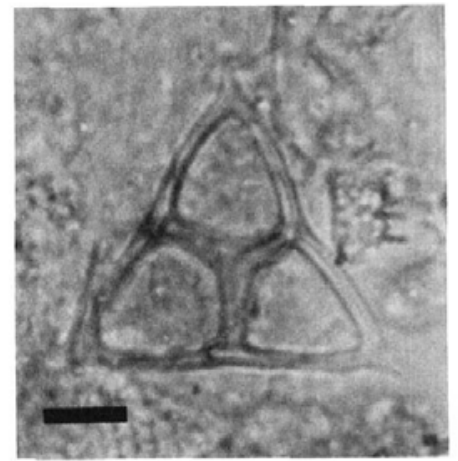

1

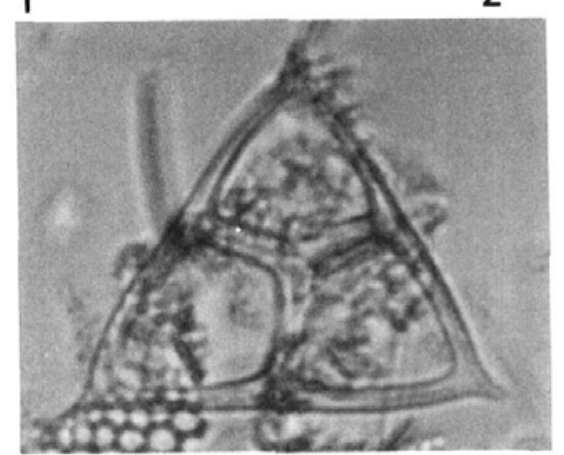

4

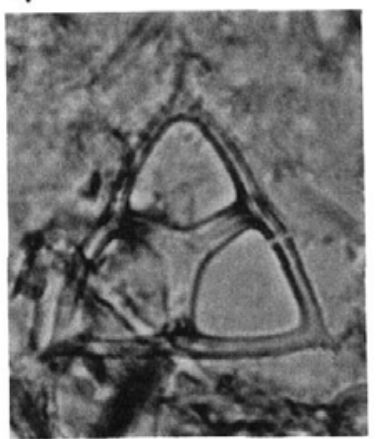

7

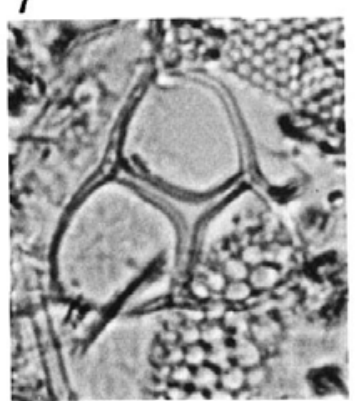

11

2

8

12
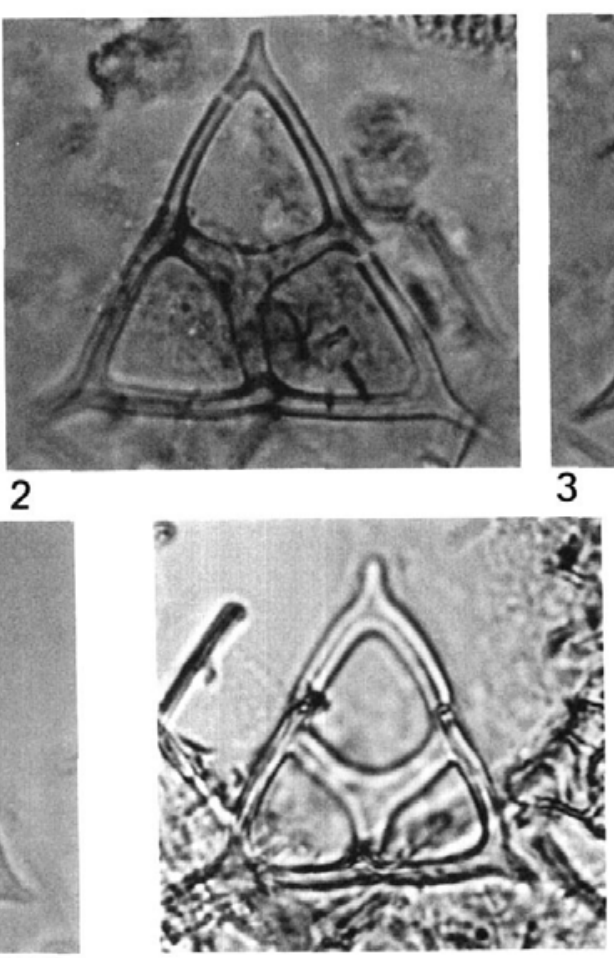
5
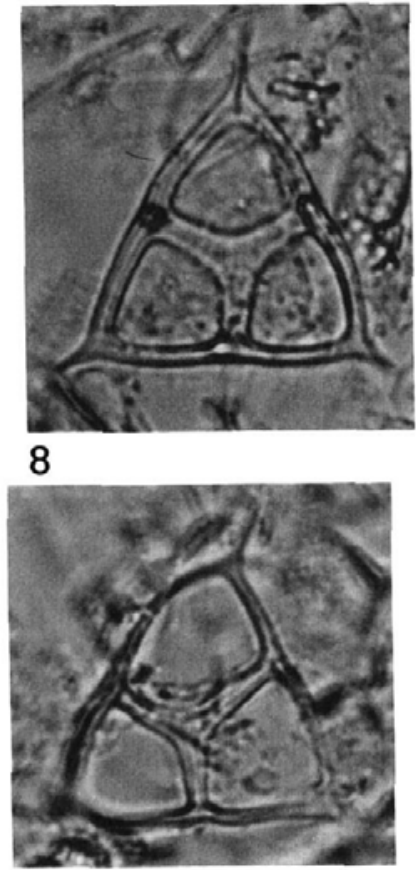

3

9
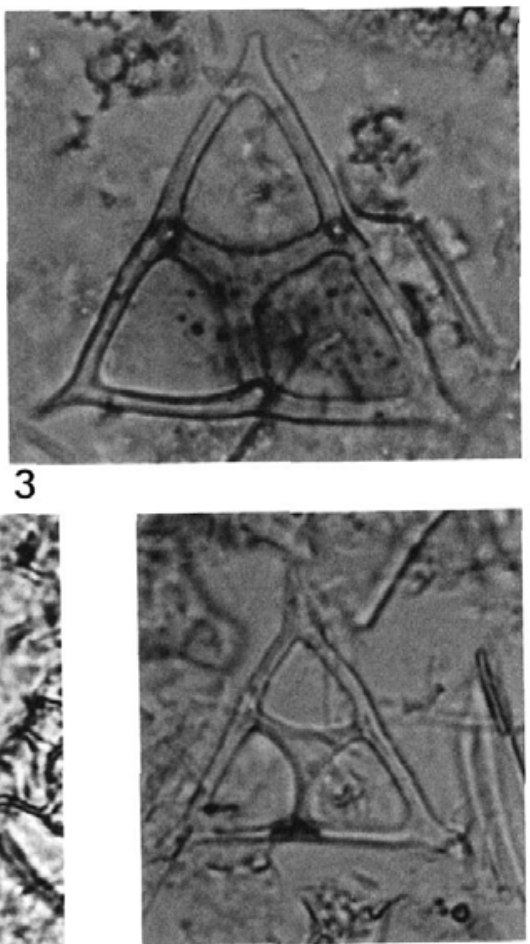

6
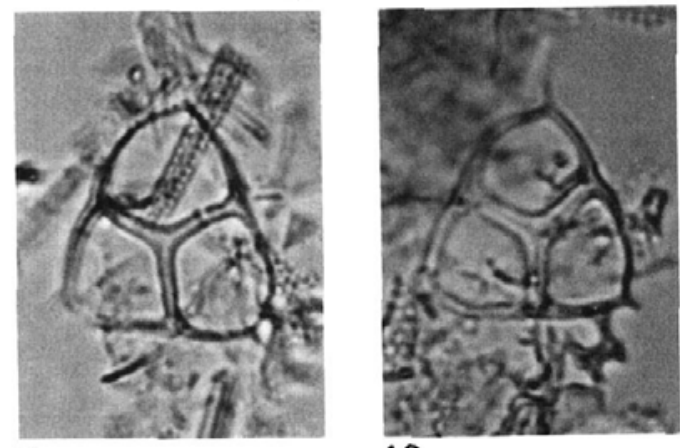

10

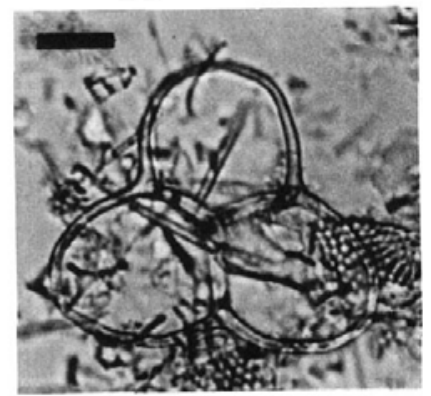

13 
C. inermis inermis (Lemmermann) Dumitrica; as Dictyocha triacantha inermis Lemmermann 1901, p. 259, pl. 10, fig. 21; $D$. triacantha var. inermis Lemm. f. inermis Glezer 1966, p. 247, pl. 8, figs. 1, 2; pl. 32, fig. 1.

C. lamellifera (Glezer) Glezer; as Dictyocha lamellifera var. lamellifera Glezer 1964, p. 48, pl. 1, fig. 2 (pl. 2, fig. 4)

C. sp. aff. C. recta (Schulz) Ling; as Dictyocha triacantha var. recta Schulz 1928, p. 250, figs. 32a, b.

C. triacantha (Ehrenberg) Hanna 1931, p. 198, pl. D, fig. 1 (s. ampl., Eocene specimen); Locker 1974, p. 634, pl. 1, fig. 10; Bukry 1978b, p. 702, pl. 1, figs. 13-15; as Dictyocha triacantha Ehrenberg 1844, p. 80 (figured by Lemmermann 1901, pl. 10, fig. 10). Remarks: Although many Eocene specimens of Corbisema superficially resemble C. triacantha, the original specimens used to typify the species lack basal pikes or apical plates and are from the upper Cenozoic (Loeblich et al. 1968; Lemmermann 1901; Locker 1974). Some Eocene specimens, identified as C. triacantha convexa Bukry (1978c) and C. regina Buk$r y$, have been distinguished by the presence of pikes and plates. Other specimens that could not be critically distinguished are tabulated as $C$. triacantha s. ampl.

Dictyocha deflandrei completa (Glezer) Bukry 1978a, p. 784; as D. deflandrei var. completa f. completa Glezer 1966, p. 244, pl. 12, figs. $14,15$.

D. hexacantha Schulz 1928, p. 255, fig. 43 (pl. 4, figs. 1-3).

D. pentagona (Schulz) Bukry \& Foster 1973, p. 827, pl. 3, fig. 10; as $D$. fibula var. pentagona Schulz 1928, p. 255, figs. 41a, b (pl. 4, fig. 4).

D. spinosa (Deflandre) Glezer 1966, p. 256, pl. 10, figs. 6?, 7, 8; as Corbisema spinosa Deflandre 1950, p. 193, figs. 178-182.

Distephanus crux (Ehrenberg) Haeckel 1887, p. 1563; as Dictyocha crux Ehrenberg 1840, p. 207; 1854, pl. 18, fig. 56; pl. 20(1), fig. 46; pl. 33(15), fig. 9; pl. 33(16), fig. 9; pl. 33(17), fig. 5.

D. quinquangellus Bukry \& Foster 1973, p. 828, pl. 5, fig. 4.

D. quintus (Bukry \& Foster) Bukry 1981b, p. 550; as D. speculum quintus (Bukry \& Foster) Bukry 1975, p. 855; as Cannopilus quintus Bukry \& Foster 1973, p. 821, pl. 1, figs. 8, 9; pl. 2, fig. 1.

D. speculum (Ehrenberg) Haeckel 1887, p. 1565; as Dictyocha speculum Ehrenberg 1839, p. 129; 1854, pl. 18, fig. 57; pl. 19, fig. 41; pl. 21 , fig. 44 ; pl. 22, fig. 47

Mesocena apiculata inflata Bukry 1978a, p. 786, pl. 3, figs. 1-3; as M. pseudoapiculata Martini 1981, p. 281, pl. 1, fig. 10 (pl. 4, fig. 14).

M. oamaruensis Schulz 1928, p. 240, figs. 10a, b (pl. 4, figs. 11-13).

M. venusta Bukry 1977, p. 834, pl. 1, figs. 11-13 (pl. 4, figs. 15-16).
Naviculopsis eobiapiculata Bukry 1978a, p. 787, pl. 4, figs. 9-16. N. foliacea Deflandre 1950, p. 204, figs. 235-240 (pl. 5, fig. 7).

\section{Coccolithophorids}

Campylosphaera dela (Bramlette \& Sullivan) Hay \& Mohler 1967, p. 1531, pl. 198, fig. 14; as Coccolithites delus Bramlette \& Sullivan 1961, p. 151, pl. 7, figs. 1a-c.

Chiasmolithus grandis (Bramlette \& Riedel) Radomski 1968, p. 560, pl. 44 , figs. 3,4 ; as Coccolithus grandis Bramlette \& Riedel 1954, p. 391, pl. 38 , figs. $1 \mathrm{a}, \mathrm{b}$

C. medius Perch-Nielsen 1971 (in part), p. 18, pl. 12, fig. 7; pl. 14, fig. 10; pl. 60, figs. 7, 8 .

C. solitus (Bramlette \& Sullivan) Gartner 1970, p. 945, fig. 16; as Coccolithus solitus Bramlette \& Sullivan 1961, p. 140, pl. 2, figs. 4a-c.

C. titus Gartner 1970, p. 945, fig. 17.

Coccolithus fenestratus (Deflandre \& Fert) Bukry 1971a, p. 792; as Discolithus fenestratus Deflandre \& Fert 1954, p. 139, pl. 11, fig. 25, textfig. 52 .

C. formosus (Kamptner) Wise 1973, p. 593, pl. 4, figs. 1-6; as Cyclococcolithus formosus Kamptner 1963, p. 163, pl. 2, fig. 8.

C. pelagicus (Wallich) Schiller 1930, pp. 91, 246; as Coccosphaera pelagica Wallich 1877, p. 348, pl. 17, figs. 1, 2, 5, 8, 9D, 10D.

C. staurion Bramlette \& Sullivan 1961, p. 140, pl. 2, figs. 5a, b, 6a-c.

Cyclicargolithus sp. aff. C. floridanus (Roth \& Hay) Bukry 1971b, p. 312; as Coccolithus floridanus Roth \& Hay, in Hay et al. 1967, p. 445, pl. 6 , figs. $1-4$.

C. pseudogammation (Bouché) Bukry 1973a, p. 677; as Coccolithus(?) pseudogammation Bouché, 1962, p. 84, pl. 1, figs. 19, 20, ?23; textfig. 6.

Cyclolithella (?) bramlettei (Hay \& Towe) Haq \& Lohmann 1976, p. 183; as Cyclolithus bramlettei Hay \& Towe 1962, p. 500, pl. 5, fig. 6; pl. 7, fig. 2.

Discoaster barbadiensis Tan 1927, p. 415.

D. bifax Bukry 1971b, p. 313, pl. 3, figs. 6-11. Remarks: Some discoaster specimens which have poorly developed proximal stems occur below the range of Discoaster bifax s. str. in the Kellogg Shale. These specimens may be evolutionary transition forms and are tabulated as $D$. sp. cf. $D$. bifax (pl. 5, figs. 8-9).

D. deflandrei Bramlette \& Riedel 1954, p. 399, pl. 39, fig. 6, text-figs. $1 \mathrm{a}-\mathrm{c}$.

D. distinctus Martini 1958, p. 363, pl. 4, figs. 17a, b.

\section{PLATE 2}

Eocene silicoflagellates from the Kellogg Shale

Scale bar for all figures equals $10 \mu \mathrm{m}$

1-3 Corbisema inermis ballantina Bukry, n. subsp. 1, holotype, USNM 347012, sample CD-15; 2, USNM 347013, sample CD-15; 3, USNM 347014, sample K-4.

\section{Corbisema lamellifera (Glezer)} Sample CD-22.
5-13 Corbisema regina Bukry, n. sp.

5, USNM 347016, sample CD-4; 6, holotype, USNM 347015, sample CD-8; 7, USNM 347017, sample CD-12; 8, USNM 347018, sample CD-6; 9, USNM 347019 , sample CD-14; 10, USNM 347020, sample CD-8;11, USNM 347021, sample CD-8; 12, USNM 347022, sample CD-14; 13, USNM 347023, sample K-7. 

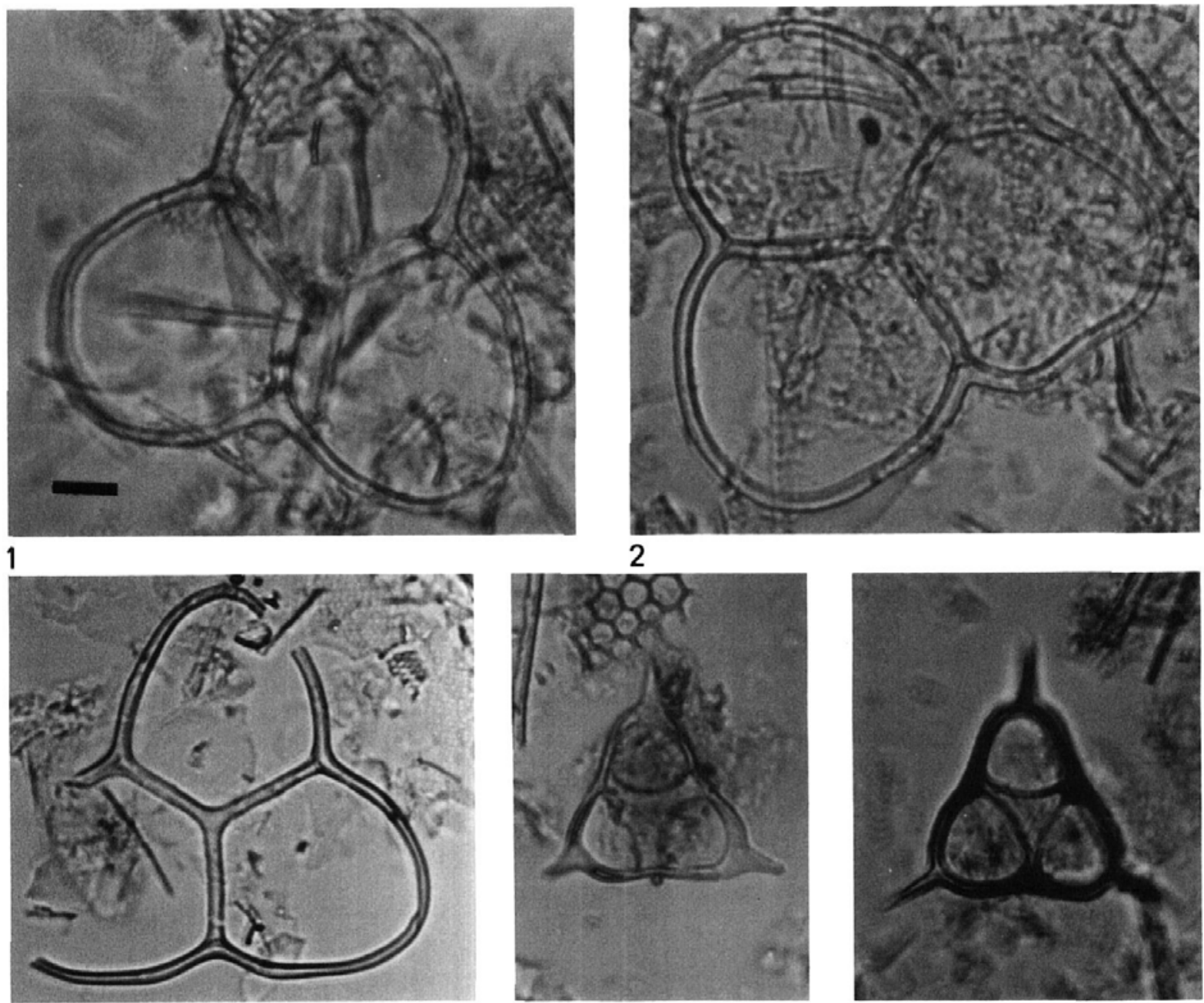

3

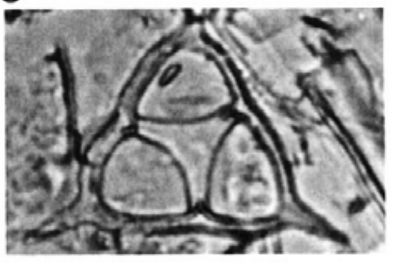

6

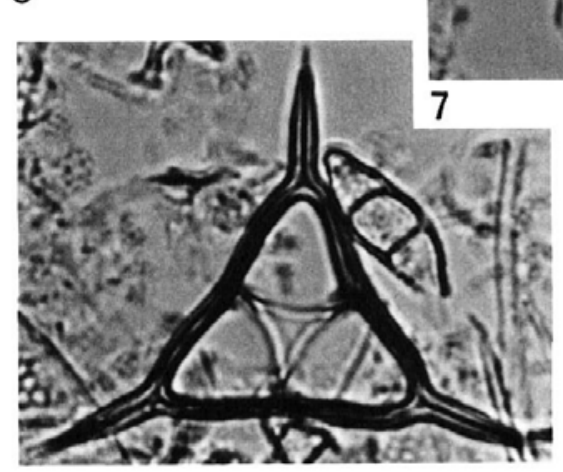

10
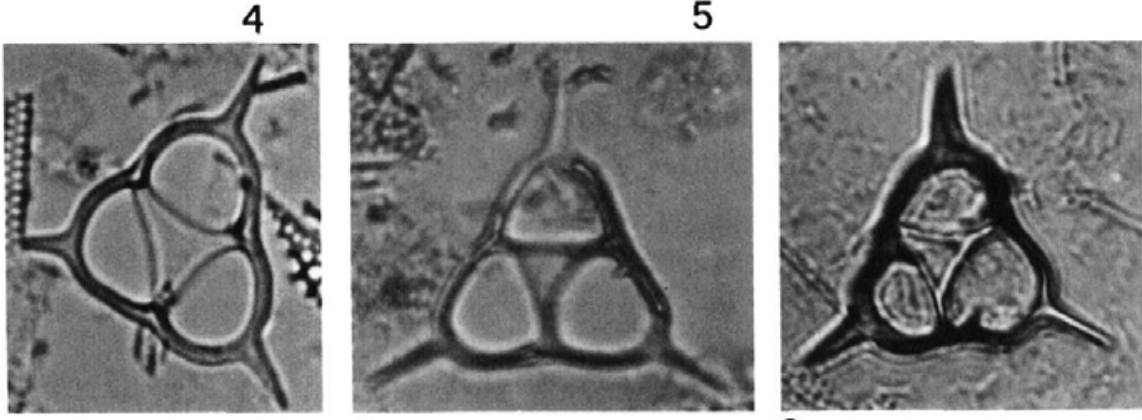

9

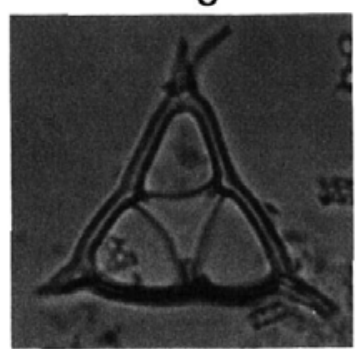

11

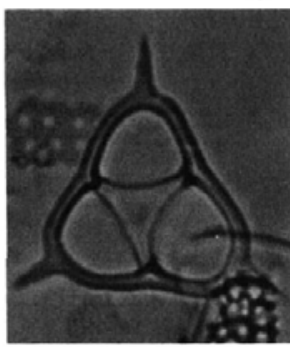

12

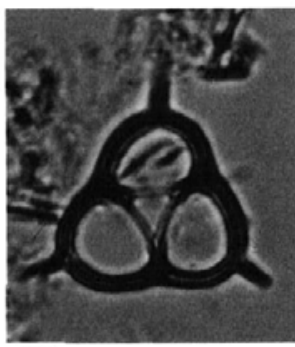

13 
D. elegans Bramlette \& Sullivan 1961, p. 159, pl. 11, figs. 16a, b.

D. sp. aff. D. martinii Stradner 1959, p. 479, figs. 45, 47.

D. nodifer (Bramlette \& Riedel) Bukry 1973a, p. 678, pl. 4, fig. 24; as $D$. tani nodifer Bramlette \& Riedel 1954, p. 397, pl. 39, fig. 2.

D. strictus Stradner 1961, p. 85, fig. 80 .

Discolithina distincta (Bramlette \& Sullivan) Levin \& Joerger 1967, p. 166, pl. 1, figs. 14a, b, 15a, b; as Discolithus distinctus Bramlette \& Sullivan 1961, p. 141, pl. 2, figs. 8a, b, 9a-c.

D. plana (Bramlette \& Sullivan) Levin 1965, p. 266, pl. 41, figs. 9a-c; as Discolithus planus Bramlette \& Sullivan 1961, p. 143, pl. 3, figs. 7a-c.

Helicosphaera bramlettei (Müller) Jafar \& Martini 1975, p. 390; as Helicopontosphaera bramlettei Müller 1970, p. 114, pl. 5, figs. 4-6.

H. sp. aff. H. heezenii (Bukry) Jafar \& Martini 1975, p. 390; as Helicopontosphaera heezenii Bukry 1971b, p. 318, pl. 5, figs. 1-5.

H. lophota (Bramlette \& Sullivan) Jafar \& Martini 1975, p. 391; as Helicopontosphaera lophota (Bramlette \& Sullivan) Bukry et al. 1971, p. 1300: as Helicosphaera seminulum lophota Bramlette \& Sullivan 1961, p. 144 , pl. 4 , figs. 3,4

Markalius inversus (Deflandre) Bramlette \& Martini 1964, p. 302, pl. 2, figs. 4-9; pl. 7, figs. 2a, b; as Cyclococcolithus leptoporus var. inversus Deflandre in Deflandre and Fert 1954, p. 150, pl. 9, figs. 4-7.

Micrantholithus aequalis Sullivan 1964, p. 188, pl. 9. fig. 6.

M. inaequalis Martini 1961, p. 7, pl. 2, fig. 13; pl. 5, fig. 45.

Nannotetrina cristata (Martini) Perch-Nielsen 1971, p. 66, pl. 56, figs. 912; as Trochoaster cristatus Martini 1958, pl. 5, fig. 26.

N. quadrata (Bramlette \& Sullivan) Bukry 1973b, p. 703; as Chiphrag. malithus? quadrata Bramlette \& Sullivan 1961, p. 157, pl. 10, figs. 14a, b, 15.

Reticulofenestra samodurovii (Hay et al.) Roth 1970, p. 852; as Apertapetra samodurovii Hay et al. 1966, p. 388, pl. 6, figs. 1-7.

R. umbilica (Levin) Martini \& Ritzkowski 1968, p. 245, pl. 1, fig.11; as Coccolithus umbilicus Levin 1965, p. 265, pl. 41, fig. 2.

Rhabdosphaera sp. aff. R. crebra (Deflandre) Bramlette \& Sullivan 1961, p. 146, pl. 5, figs. 1-3; as Rhabdolithus creber Deflandre in Deflandre and Fert 1954, p. 157, pl. 12, figs. 31-33.

R. sp. cf. R. morionum (Deflandre) Bramlette \& Sullivan 1961, p. 146 , pl. 5, figs. 12a, b, 13; as Calyptrolithus morionum Deflandre in Deflandre and Fert 1954, p. 147, pl. 12, figs. 7, 8, text-figs. 63, 64.

R. spinula Levin 1965, p. 267, pl. 42, fig. 3.

Scampanella bispinosa Perch-Nielsen in Perch-Nielsen and Franz 1977, p. 853 , pl. 3, figs. 1-7; pl. 6, figs. 12-14, 15-17, text-fig. 3(14).

Sphenolithus moriformis (Brönnimann \& Stradner) Bramlette \& Wilcoxon 1967, p. 124, pl. 3, figs. 1-6; as Nannoturbella moriformis Brönnimann \& Stradner 1960, p. 368, figs. 11-16.

S. radians Deflandre in Grassé 1952, p. 466, figs. 343J-K, 363A-G.

S. spiniger Bukry 1971b, p. 321, pl. 6, figs. 10-12; pl. 7, figs. 1, 2.

Syracosphaera labrosa Bukry \& Bramlette 1969, p. 141, pl. 3, figs. 1517

Transversopontis pulcher (Deflandre) Perch-Nielsen 1967, p. 21, pl. 3, figs. 9-11; as Discolithus pulcher Deflandre in Deflandre and Fert 1954, p. 142, pl. 12, figs. 17, 18.

T. pulcheroides (Sullivan) Perch-Nielsen 1971, p. 40, pl. 33, figs. 3, 7; as Discolithus pulcheroides Sullivan 1964, p. 183, pl. 4, figs. 7a, b.

Zygolithus dubius Deflandre in Deflandre and Fert 1954, p. 149, textfigs. $43,44,68$.

Zygrhablithus bijugatus (Deflandre) Deflandre 1959, p. 135; as Zygolithus bijugatus Deflandre in Deflandre and Fert 1954, p. 148, pl. 11. figs. 20,21 , text-fig. 59 .

\section{Diatoms}

Actinoptychus undulatus (Bailey) Ralfs; as A. senarius (Ehrenberg) Ehrenberg-Kanaya 1957, pl. 7, fig. 17 (pl. 7, fig. 8).

Asterolampra insignis Schmidt 1874-1959, pl. 137, figs. 1-3.

Chaetoceros spines (pl. 8, fig. 1).

Coscinodiscus argus var. 1 (pl. 7, fig. 10).

C. bulliens Schmidt-Kanaya 1975, pl. 5, fig. 3.

C. marginatus Ehrenberg-Kanaya 1957, pl. 6, fig. 1 (pl. 7, fig. 11).

C. radiatus Ehrenberg-Kanaya 1957, pl. 6, figs. 2-4.

C. tuberculatus var. atlantica Glezer \& Jousé; as $C$. tuberculatus Greville-Kanaya 1957. pl. 6, figs. 6-8 (pl. 6, figs. 3-4)

C. symbolophorus Grunow-Schrader and Fenner 1976, pl. 20, fig. 1.

$C$. spp. Includes $C$. argus Ehrenberg, $C$. oculusiridis Ehrenberg, etc.

Craspedodiscus oblongus (Greville) Grunow; as Coscinodiscus oblongus Greville-Kanaya 1957, pl. 6, figs. 2-4 (pl. 6, figs. 1-2).

Cymatosira spp. Compare Cymatosira spp. of Schrader and Fenner 1976, pl. 20, figs. 12, 13.

Hantzschia sp.

Hemiaulus polycystinorum var. mesolepta Grunow-Kanaya 1957, pl. 7, figs. $12-14$ (pl. 8, figs. 3, 5).

H. spp. Included is H. polymorphus Grunow-Kanaya 1957, pl. 7, figs. 10, 11.

Melosira architecturalis Brun; as Cyclotella hannae Kanaya 1957, pl. 3, figs. $10-14$ (pl. 7, figs. 1-3).

M. sulcata (Ehrenberg) Kutzing-Kanaya 1957, pl. 3, figs. 1, 2 (pl. 7, fig. 4).

Monobrachia simplex Schrader in Schrader and Fenner 1976, pl. 41, figs. 15, 16, 18, 20.

Pseudopoldosira bella Glezer \& Posnova-Fenner 1977, pl. 10, figs. 2,

3, 6-8; as Hercotheca? sp. a of Kanaya 1957, pl. 8, figs. 15-17 (pl. 7, fig. 9).

Pterotheca aculeifera (Grunow) Van Heurck; as Pyxilla aculeifera Grunow-Kanaya 1957, pl. 8, figs. 1, 2 (pl. 8, fig. 13).

P. danica (Grunow) Forti; as Pyxilla danica (Grunow) Hanna-Kanaya 1957, pl. 8, figs. 5-7 (pl. 8, fig. 10)

P. gracillima Fenner 1977, pl. 12, figs. 5, 6 (pl. 8, fig. 11)

P. sp. (pl. 8, fig. 12).

\section{PLATE 3}

Eocene silicoflagellates from the Kellogg Shale Scale bar for all figures equals $10 \mu \mathrm{m}$

1-14 Dictyocha byronalis Bukry, n. sp. 1, USNM 347025, sample K-4; 2, USNM 347026, sample K-4; 3 , holotype, USNM 347024, sample K-6; 4, USNM 347027, sample CD-5; 5, USNM 347028, sample CD-6; 6, USNM 347029, sample CD-15; 7, USNM 347030, sample K-5; 8, USNM
347031, sample K-2; 9, USNM 347032, sample CD16; 10, USNM 347033, sample CD-14;11, variant, USNM 347034, sample CD-23; 12, fibuloid, USNM 347035, sample K-6; 13, medusoid, USNM 347036, sample CD-6; 14, giant, USNM 347037, sample K-11. 


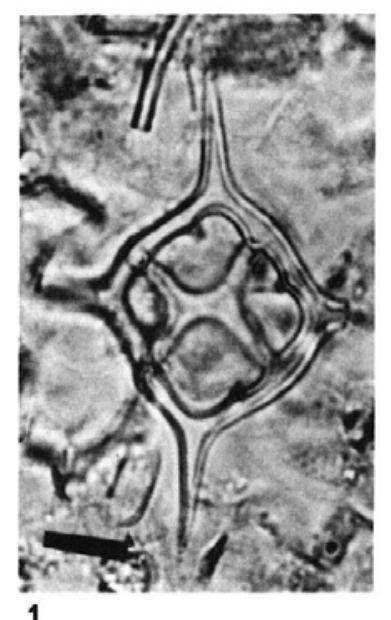

1

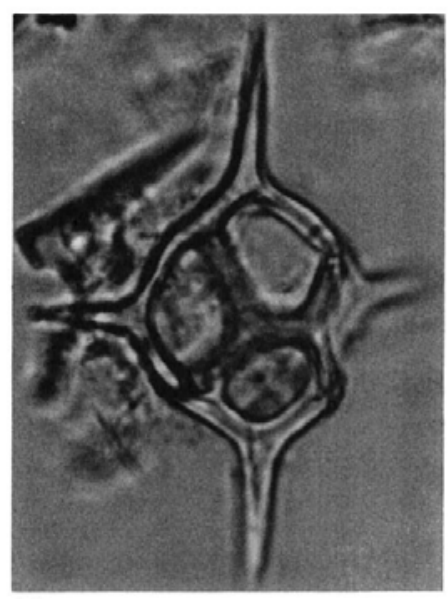

2

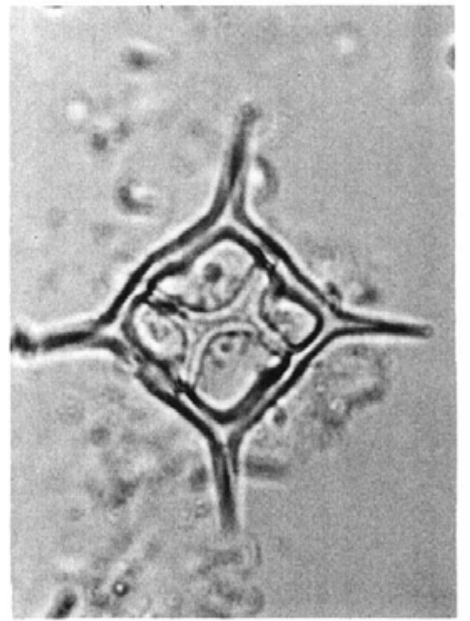

5

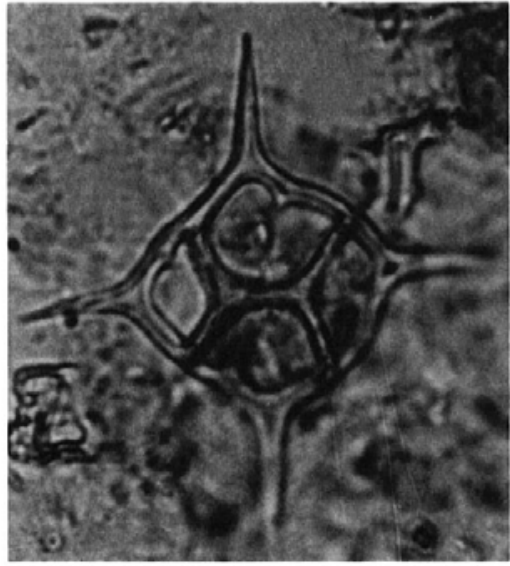

9

6

10
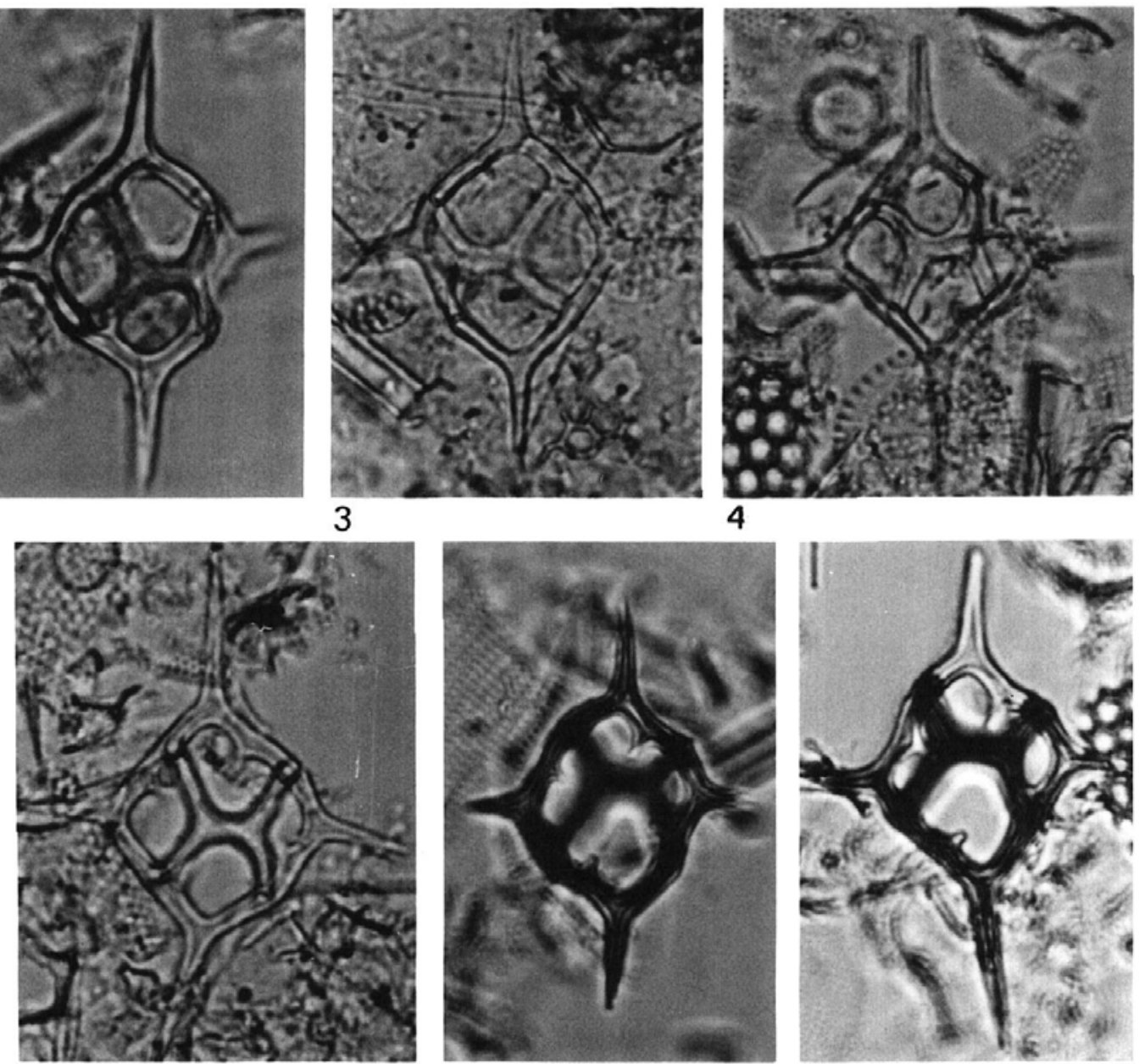

4
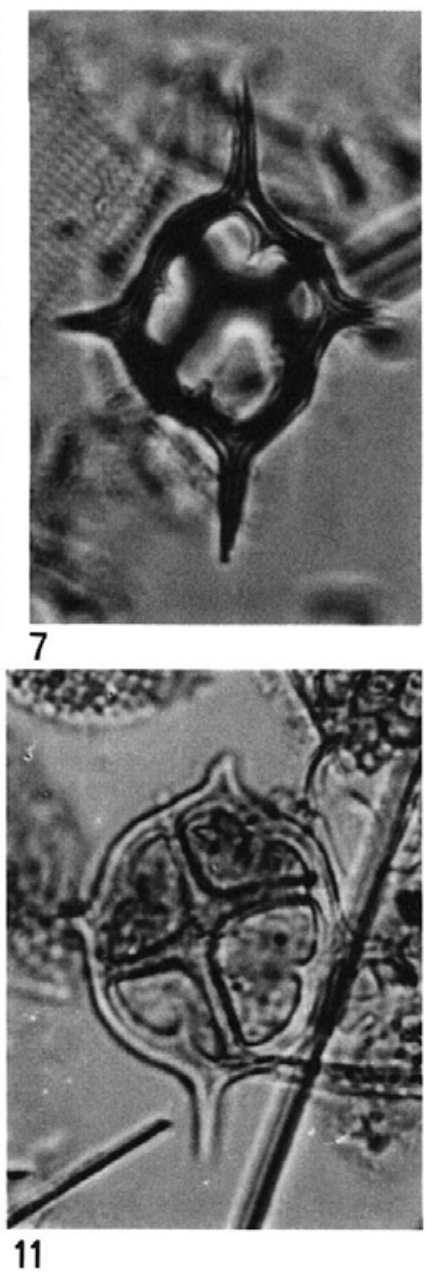

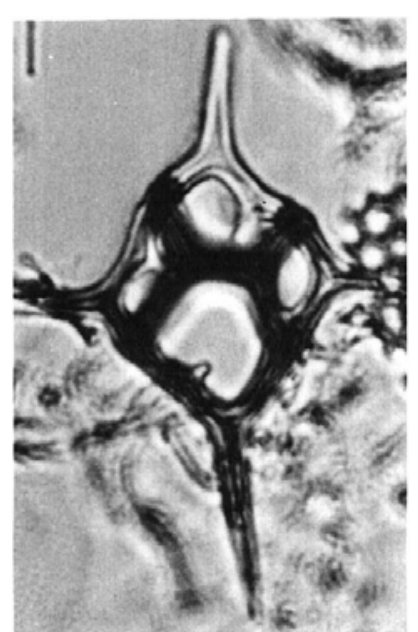

8

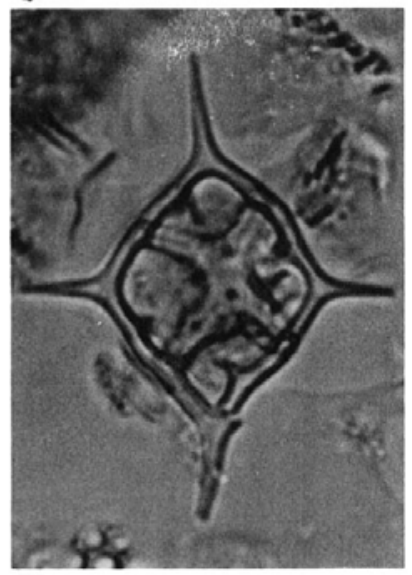

12

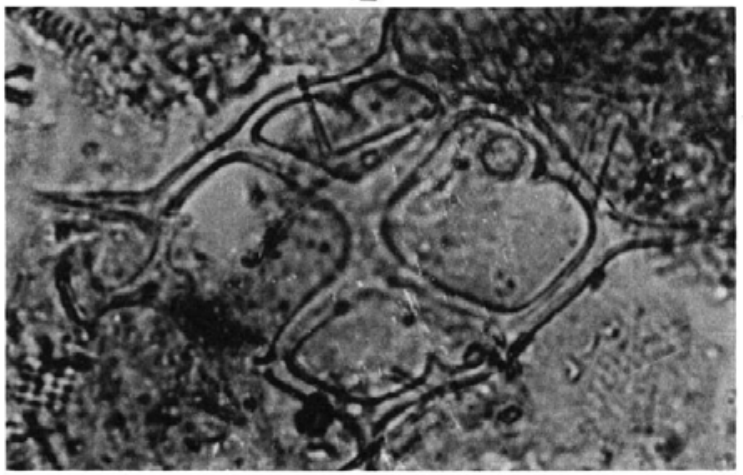

14 
Pyxilla gracilis Tempère \& Forti; as Pyrgupyxis gracilis (Tempère \& Forti) Hendey-Fenner 1977, pl. 19, figs. 1-3 (pl. 8, fig. 7).

P. intermedia Tempère \& Forti-Kanaya 1957, pl. 8, fig. 11.

Rhizosolenia hebetata f. semispina (Hensen) Gran-Schrader and Fenner 1976, pl. 7, fig. 2; pl. 9, fig. 15.

R. sp. 1 (pl. 8, fig. 6).

$R$. spp. Included here are other forms of Rhizosolenia which have sparse and sporadic occurrences.

Riedelia claviger (Schmidt) Schrader \& Fenner 1976, pl. 41, figs. 6-8, 9; pl. 42, figs. $3,4,10,11,15$; as Clavicula? sp. of Kanaya 1957, pl. 7 , fig. 9 (pl. 8, fig. 4)

R. sp. 1; as Riedelia? sp. 1 of Schrader \& Fenner 1976, pl. 41, fig. 1 (pl. 8, fig. 2).

Sceptroneis sp. cf. S. talwanii Schrader \& Fenner 1976, pl. 24, figs. $27-$ 29 (pl. 8, fig. 9).

S. tenue Schrader \& Fenner 1976, pl. 3, figs. 1-4; pl. 25, figs. 12, 22, 24.

Stephanopyxis grunowii Grove \& Sturt-Schrader and Fenner 1976, pl. 20 , fig. 8 , pl. 31 , fig. 3 .

S. turris (Greville \& Arnott) Ralfs-Kanaya 1957, pl. 3, figs. 3-5 (pl. 7, fig. 7).

Stictodiscus kittonianus Greville-Schrader and Fenner 1976, pl. 35, fig. 27.

Thalassiosira sp. 1 (pl. 7, fig. 5).

T. sp. 2; as Thalassiosira? sp. 1 of Fenner 1977, pl. 3, figs. 7, 8 (pl. 7, fig. 6).

Triceratium barbadense Greville-Fenner 1977, pl. 30, figs. 12-14.

T. brachiatum Brightwell-Fenner 1977, pl. 30, figs. 27-31.

T. inconspicuum Greville-Fenner 1977, pl. 30, figs. 21, 22; Kanaya 1957, pl. 7, fig. 8 (pl. 6, fig. 5).

$T$. inconspicuum var. trilobata Fenner 1977, pl. 30, figs. 23-26; as $T$. barbadense Greville-Kanaya 1957, pl. 7, figs. 1-4 (pl. 6, figs. 6-7).

T. kanayae Fenner; as T. schulzii Jousé-Fenner 1977, pl. 30, figs. 111, pl. 37, fig. 3; as T. sp. a of Kanaya 1957, pl. 7, figs. 5-7 (pl. 6, fig. 9).

T. kanayae var. quadrilobata Fenner; as T. schulzii var. quadrilobata Fenner 1977, pl. 30, figs. 15-20.

$T$. sp. 3 of Schrader and Fenner 1976, pl. 27, fig. 7.

\section{Planktonic foraminifers}

Acarinina aspensis (Colom)-Blow 1979, p. 908, pl. 148, figs. 7-9; pl. 153, figs. 5-6; pl. 157, figs. 1-6; pl. 165, figs. 5, 6. Remarks: Samples CD-11, CD-12, and CD-15 are dominated by spinose forms with four to seven chambers in the final whorl that also show a great deal of variability in the extent of the umbilicus and in development of an acute periphery. Although a number of names could be applied to various extremes seen in the populations, the assemblages basically contain Acarinina aspensis with subordinate amounts of $A$. soldadoensis and Truncorotaloides collacteus. Forms with five to seven chambers in the last whorl, a wide, open and deep umbilicus, and a rounded periphery are referred to Acarinina aspensis. Forms with four spherical to subspherical chambers in the final whorl, a wide and deep umbilicus, and a rounded periphery are referred to Acarinina soladoensis. Forms with five chambers in the final whorl, a restricted umbilicus, and a tendency to develop an acute periphery are referred to Truncorotaloides collacteus. The separation between Acarinina and Truncorotaloides is arbitrary in this case as none of the specimens in these samples show evidence of supplementary apertures (pl. 9, figs. 10-11).

Acarinina bullbrooki (Bolli)-Bolli 1957c, p. 167, pl. 38, figs. 4, 5.

Acarinina cuneicamerata Blow 1979, p. 924, pl. 145, figs. 4-6; pl. 148, figs. 4-6; pl. 153, figs. $1-4$; pl. 156, figs. $1-4$; pl. 165, figs. $4,7$.

Acarinina soldadoenis (Brönnimann)-Bolli 1957a, p. 71, pl. 16, figs. 79 (pl. 9, figs. 7-8).

Acarinina spp.

Chiloguembelina spp.

Clavigerinella sp. Remarks: Only 1 juvenile specimen of Clavigerinella was found.

Globigerinatheka sp. (spp.). Remarks: Several juvenile representatives of Globigerinatheka were found in samples CD-8 and CD-11. It is likely that these forms were recorded as Globigerina index by Schmidt 1970.

Globorotalia frontosa (Subbotina)-Poore and Brabb 1977, p. 259, pl. 2 , figs. $1,2$.

Globorotalia nana Bolli 1957b, p. 118, pl. 28, fig. 3.

Globorotaloides sp.

Globorotaloides wilsoni (Cole)-Poore and Brabb 1977, p. 263, pl. 2 ,

\section{PLATE 4}

Eocene silicoflagellates and Macrora from the Kellogg Shale Scale bar for figures $1,2,4-13$ equals $10 \mu \mathrm{m}$; for figures $3,14-19$ it equals $20 \mu \mathrm{m}$

\section{1-3 Dictyocha hexacantha Schulz}

All from sample CD-4; 3 , figured specimen of Corbisema angularis at left.

4 Dictyocha pentagona (Schulz) Sample CD-12.

\section{5-8 Macrora barbadiensis (Deflandre)} 5, sample CD-12; 6-8, sample K-6.

9-10 Macrora najae Bukry

9, sample K-5; 10, sample CD-14.
11-13 Mesocena oamaruensis Schulz

11 , sample K-8; 12 , sample K-5; 13 , sample CD12.

14 Mesocena apiculata inflata Bukry Sample CD-17.

15-16 Mesocena venusta Bukry 15, sample CD-16; 16, sample CD-8.

17-19 Naviculopsis americana Bukry, n. sp. 17, USNM 347039, sample K-2; 18, USNM 347040, sample K-11; 19, USNM 347041, sample $\mathrm{K}-2$. 


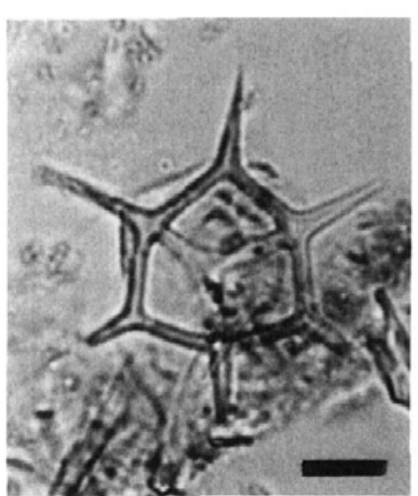

1

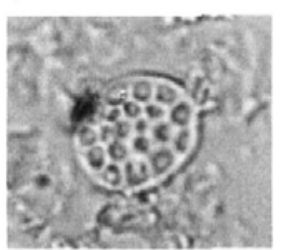

5

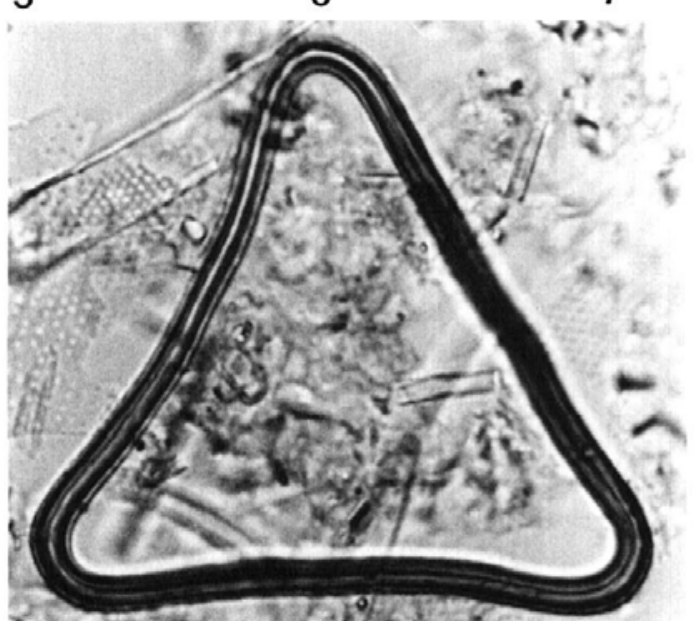

11

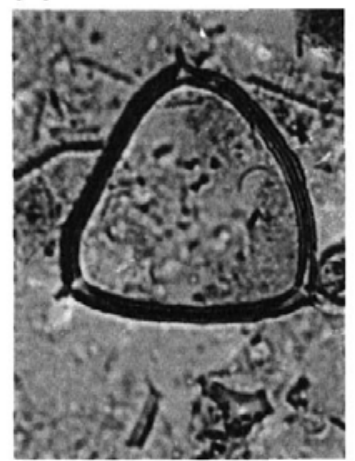

14

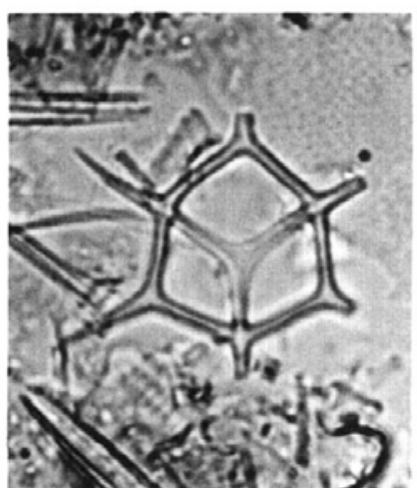

2

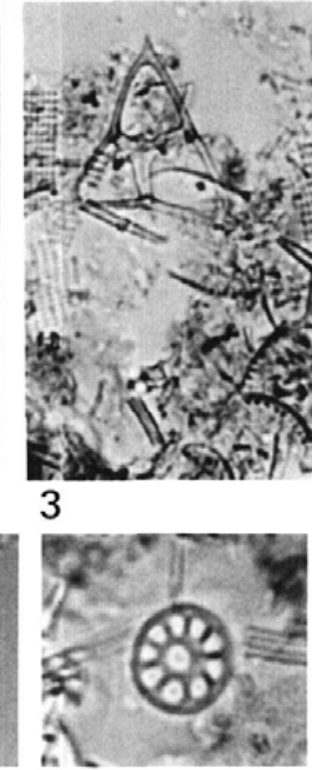

8

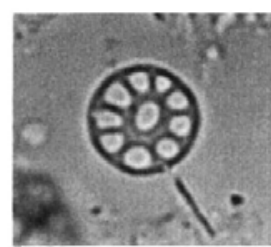

7

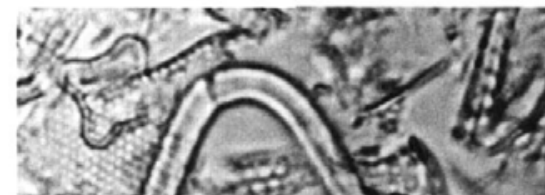

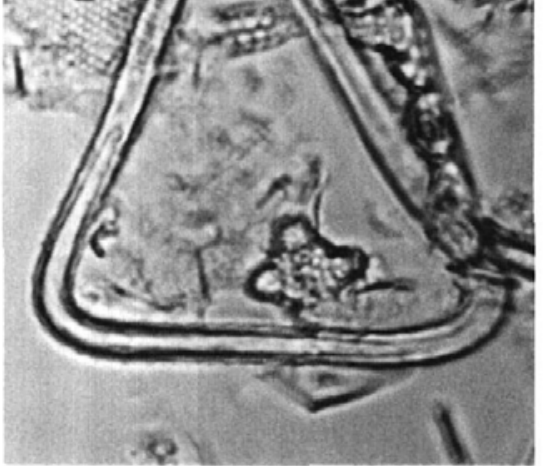

12

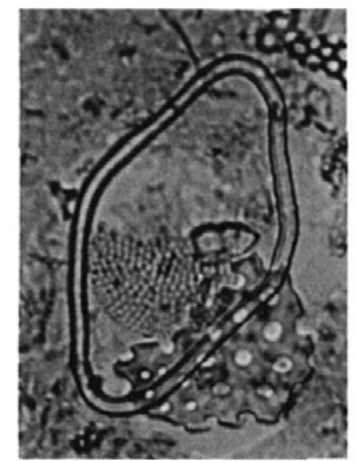

15

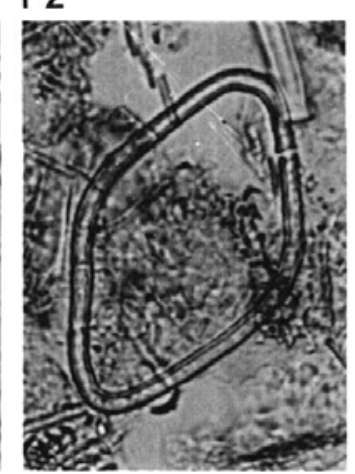

16

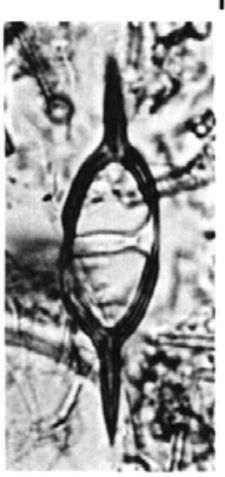

17

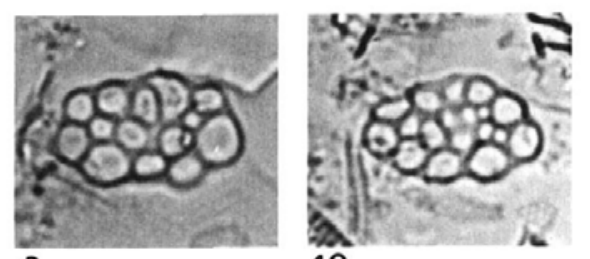

10

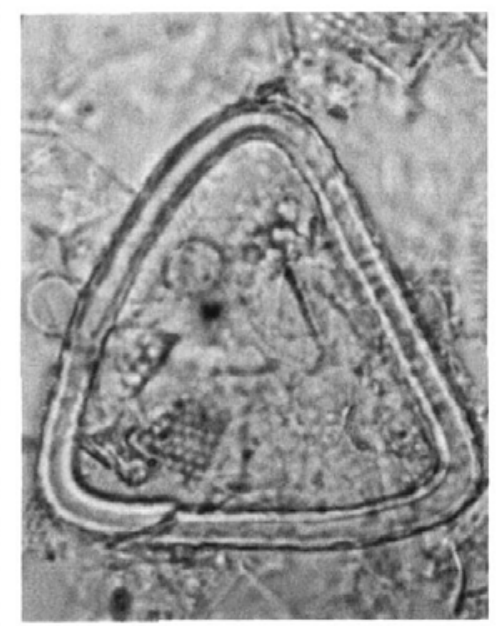

13

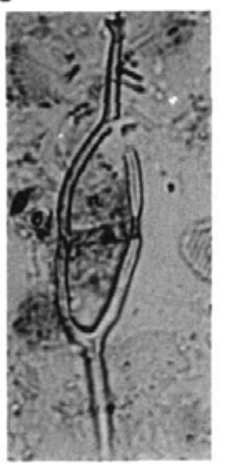

18

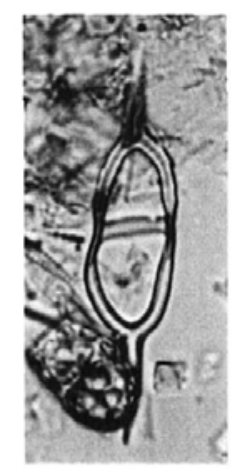

19 
figs. 10-13 (pl. 9, figs. 9, 12). Remarks: Globorotaloides wilsoni as recognized here and by Poore and Brabb (1977) appears very similar if not identical to Globorotalia griffinae Blow.

Guembelitria columbiana Howe-Beckmann 1957, p. 92, pl. 21, fig. 16 (pl. 9, fig. 4).

Pseudohastigerina danvillensis (Howe \& Wallace)-Blow 1979, p. 1181; pl. 159 , figs. 6,7 ; pl. 161 , figs. 2-7; pl. 166, figs. 2-10; pl. 253, figs. 10-12. Remarks: In this study, we assign compressed specimens of Pseudohastigerina with curved sutures to $P$. danvillensis and restrict $P$. micra to forms with subspherical chambers and more radial sutures. (See Blow 1979 for discussion.) Pseudohastigerina micra of Schmidt (1970) is equivalent to $P$. danvillensis of this study (pl. 9, figs. 1-3).

Pseudohastigerina lillisi (Church)-McKeel and Lipps 1975, p. 260, pl. 3, fig. 7; pl. 4, fig. 5 .

Pseudohastigerina micra (Cole) Blow 1979, p. 1185, pl. 166, fig. 11; pl. 198, figs. 8, 9; pl. 253, figs. 1-9.

Subbotina eocaenica (Terquem) sensu Blow 1979, p. 1260, pl. 151, fig 10; pl. 158, fig. 9. Remarks: A large, robust subbotinid in samples from the Kellogg Shale which closely resembles Subbotina eocaenica of Blow (1979, pl. 151, fig. 10; pl. 158, fig. 9) (pl. 9, figs. 5-6).

Truncorotaloides collacteus (Finlay)-Poore and Brabb 1977, p. 269, pl. 5, figs. 5-7.

Truncorotaloides rohri Bronnimann \& Bermudez-Bolli 1957c, p. 170, pl. 39, figs. 8-12. Remarks: A few specimens in samples CD-11 and CD12 with 5-7 chambers in the last whorl, a restricted umbilicus and an umbilical-extraumbilical aperture are referred to Truncorotaloides rohri.

\section{Incertae sedis}

Macrora barbadiensis (Deflandre) Bukry 1977, p. 832, pl. 2, figs. 3, 8; as Pseudorocella barbadiensis Deflandre 1938 (in part), p. 91, fide Loeblich et al. 1968, p. 139, pl. 33, figs. 4-13, 15-19 (not 14) (pl. 4, figs. 5-8).

Macrora najae Bukry 1977, p. 833, pl. 2, figs. 9-12 (pl. 4, figs. 9-10).

\section{ACKNOWLEDGMENTS}

We thank Gerta Keller and Joyce Blueford of the U.S. Geological Survey and Ken Finger of Chevron Oil Company for their review of the manuscript. Samples for comparative studies were provided by the National Science Foundation and the Deep Sea Drilling Project.

\section{REFERENCES}

ALMGREN, A. A., and MCDOUGALL, K., 1975. Stratigraphic relationship of the middle Eocene Kellogg and Sidney Flat shales of northern California. Paleogene Symposium and Selected Technical Papers, Annual Meeting-Pacific Sections-A.A.P.G.-S.E.P.M.-S.E.G., Long Beach, California, April, 1975:1-13.

BARRON, J. A., 1976. Revised Miocene and Pliocene diatom biostratigraphy of Upper Newport Bay, Newport Beach, California. Marine Micropal., 1:27-63.

BECKMANN, J. P., 1957. Chiloguembelina Loeblich and Tappan and related foraminifera from the lower Tertiary of Trinidad. U.S. Natl. Mus., Bull., 215:83-95

BERGGREN, W. A., KENT, D. V., and FLYNN, J. J., In press. Paleogene geochronology and chronostratigraphy. In: Snelling, N. J., Ed., Geochronology and the geological record. Geol. Soc. London, Spec. Paper.

BLOW, W. H., 1969. Late middle Eocene to Recent planktonic foraminiferal biostratigraphy. Proc. 1st Internat. Conf. Planktonic Microfossils, 1:199-422.

1979. The Cainozoic Globigerinida. Leiden, The Netherlands: E. J. Brill, Pts. I, II, III.

BOERSMA, A., 1977. Cenozoic planktonic foraminifera-DSDP Leg 39 (South Atlantic). In: Supko, P. R., Perch-Nielsen, K., et al., Initial Re-

\section{PLATE 5}

Eocene silicoflagellates, coccoliths, and ebridians from the Kellogg Shale Scale bar for figures 1-7 equals $20 \mu \mathrm{m}$; for figures 8-21 it equals $5 \mu \mathrm{m}$; for figures 22-25 it equals $10 \mu \mathrm{m}$

1-5 Naviculopsis americana Bukry, n. sp.

1, USNM 347042, sample CD-13; 2, holotype, USNM 347038, sample CD-11; 3, USNM 347043, sample K-2; 4, USNM 347044, sample K-7; 5 , USNM 347045, sample K-11.

6 Naviculopsis constricta (Schulz) emend. Sample K-7.

7 Naviculopsis foliacea Deflandre Sample CD-12.

8-9 Discoaster bifax Bukry Two specimens in side view (lower right) and distal view (upper left) at different focus levels from a smear slide of sample K-4.
10-21 Helicosphaera neolophota Bukry, n. sp.

10-11, holotype, USNM 347046, sample K-4; bright field (BF) and cross-polarized light (XP); 12-13, USNM 347047, sample K-4 (BF and XP); 14-15, USNM 347048, sample O-1 (BF and XP); 16-17, USNM 347049, sample O-1 (BF and XP); 18-19, USNM 347050, sample K-4 (BF and XP); 20-21, USNM 347051, sample K-4 (BF and XP).

22-24 Ebridians

22, sample CD-11; 23-24, sample CD-12.

25 Aberrant silicoflagellate Sample CD-15. 

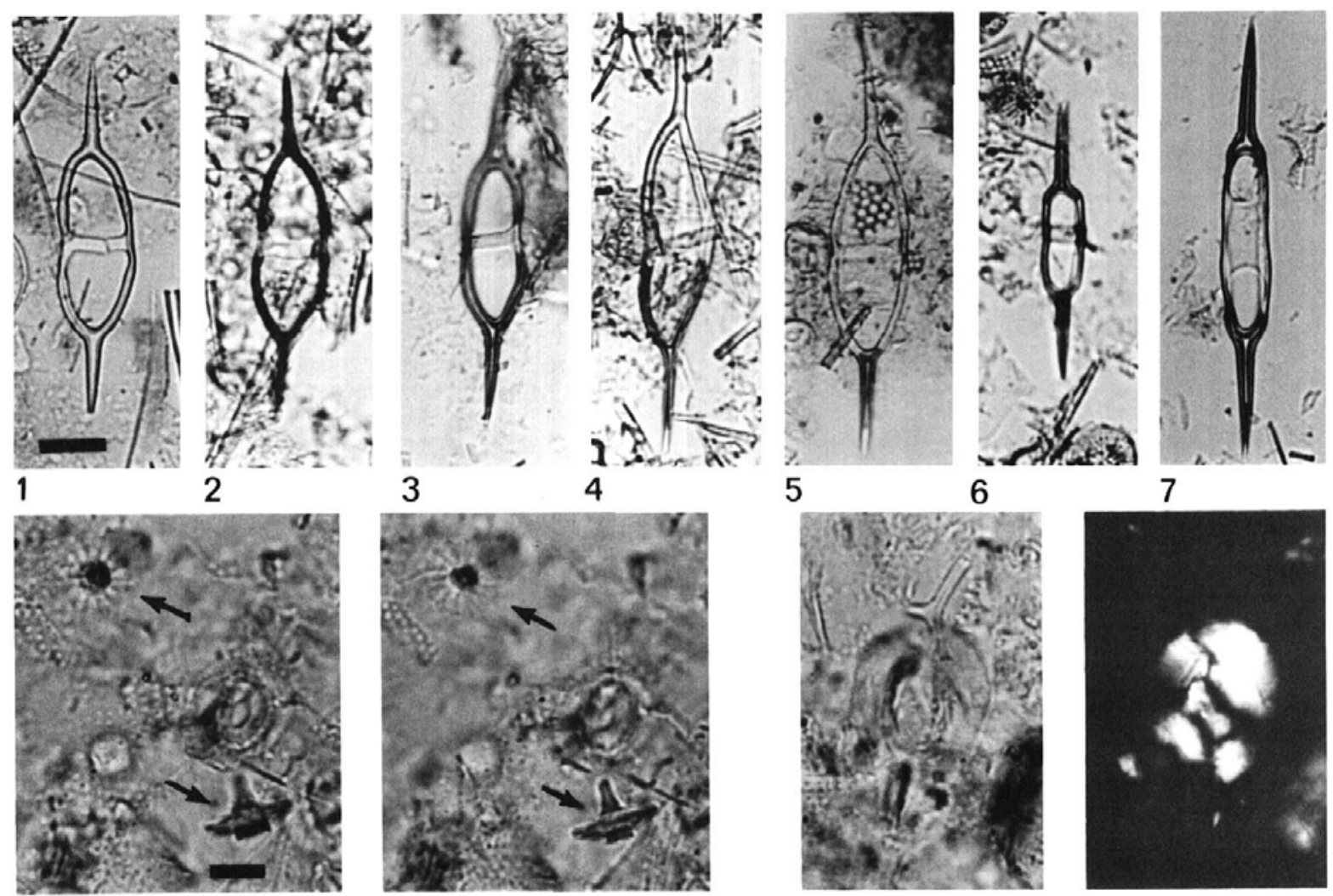
8

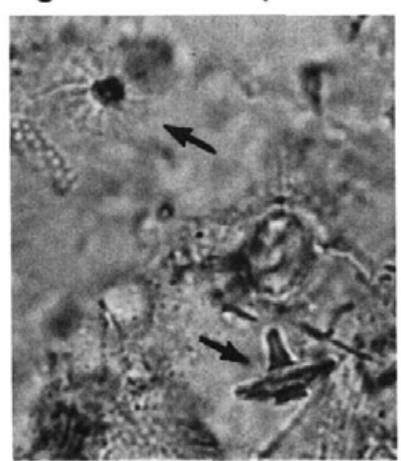

5
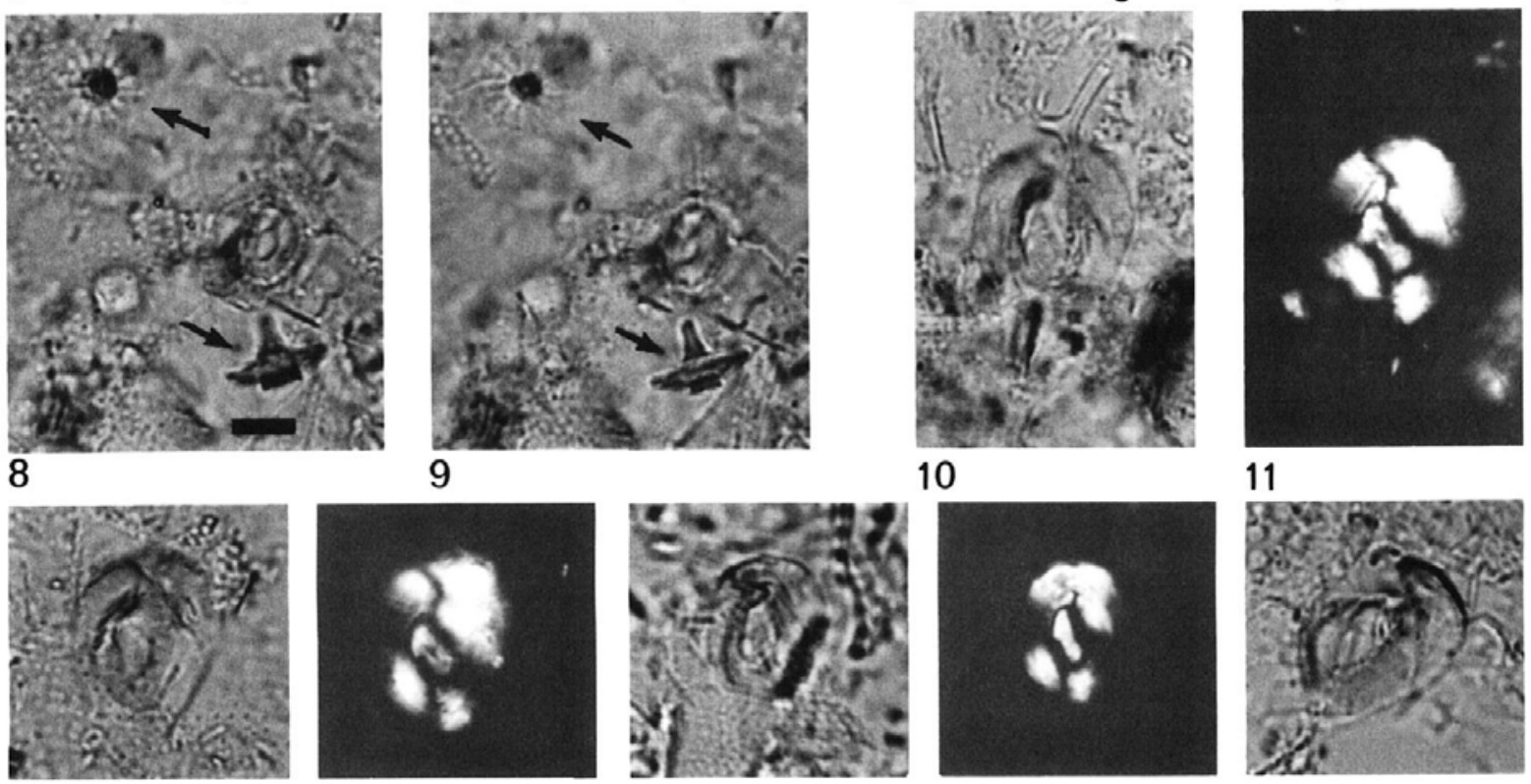

9

10

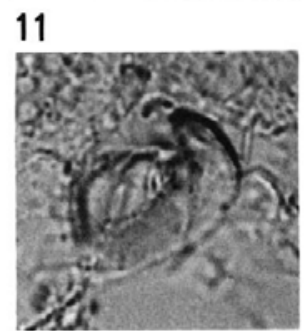

12
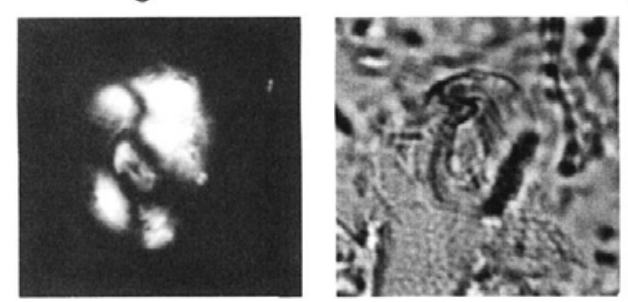

14

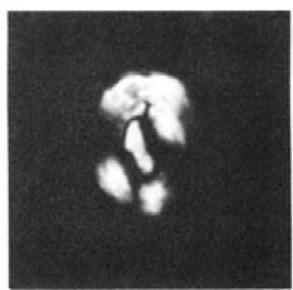

15

16
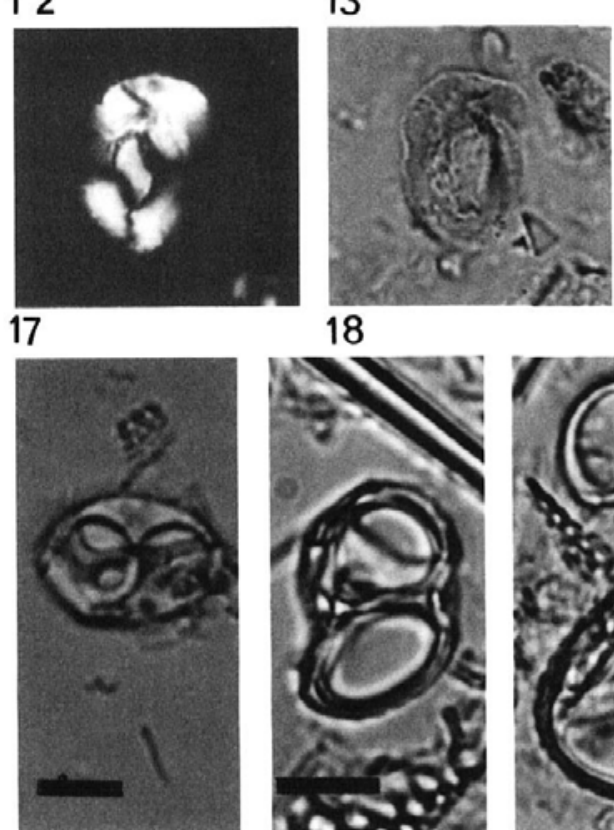

22

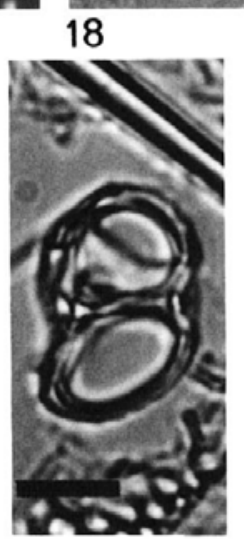

23

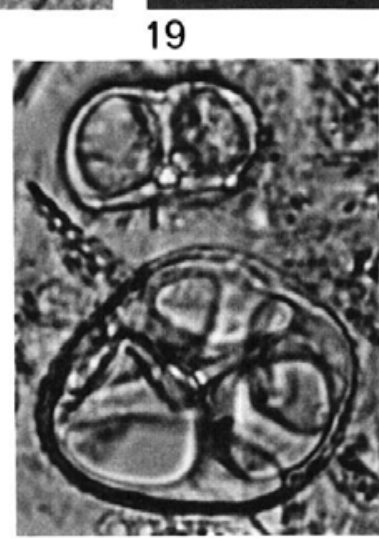

24
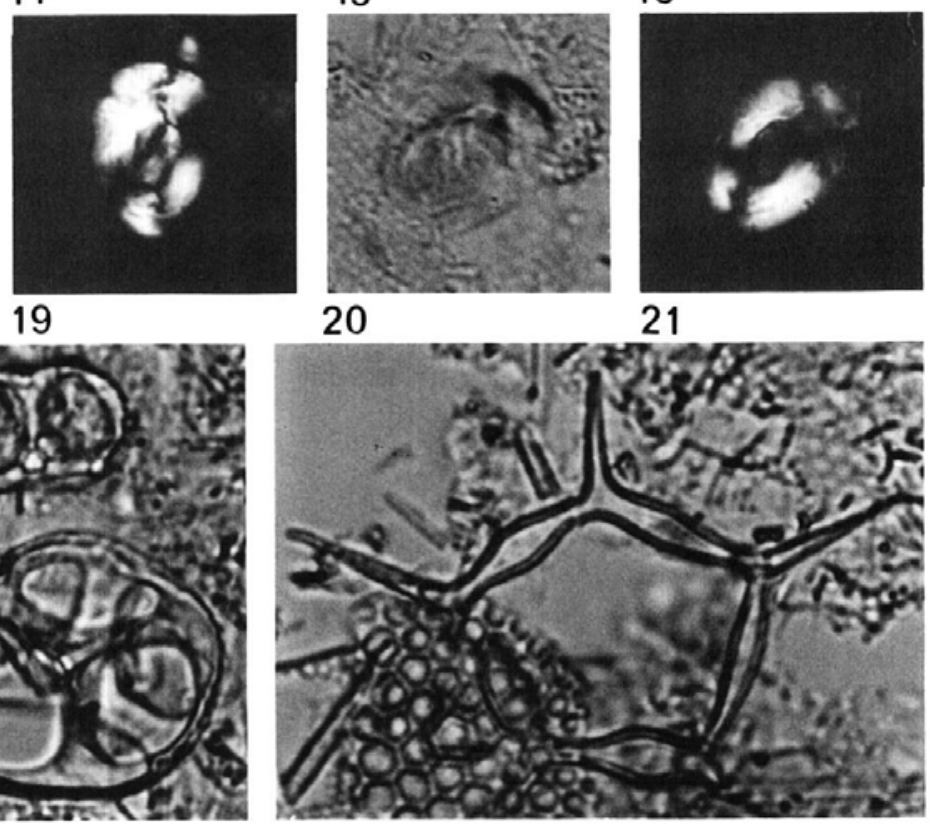

25 
ports of the Deep Sea Drilling Project, Volume 39:567-590. Washing. ton, D.C.: U.S. Government Printing Office.

BOLLI, H. M., 1957a. The genera Globigerina and Globorotalia in the Paleocene-Lower Eocene Lizard Springs Formation of Trinidad, B.W.I. U.S. Natl. Mus., Bull., 215:61-81.

- 1957b. Planktonic foraminifera from the Oligocene-Miocene Cipero and Lenqua Formations of Trinidad, B.W.I. U.S. Natl. Mus., Bull., 215:97-123.

1957c. Planktonic foraminifera from the Eocene Navet and San Fernando Formations of Trinidad, B.W.I. U.S. Natl. Mus., Bull., 215: 155-172.

BOUCHÉ, P. M., 1962. Nannofossiles calcaires du Lutetien du Bassin de Paris. Rev. Micropal., 5(2):75-103.

BRAMLETTE, M. N., and MARTINI, E., 1964. The great change in calcareous nannoplankton fossils between the Maestrichtian and Danian. Micropaleontology, 10(3):291-322.

BRAMLETTE, M. N., and RIEDEL, W. R., 1954. Stratigraphic value of discoasters and some other microfossils related to Recent coccolithophores. Jour. Pal., 28(4):385-403.

BRAMLETTE, M. N., and SULLIVAN, F. R., 1961. Coccolithophorids and related nannoplankton of the early Tertiary in California. Micropaleontology, 7(2):129-188.

BRAMLETTE, M. N., and WILCOXON, J. A., 1967. Middle Tertiary calcareous nannoplankton of the Cipero Section, Trinidad, W. I. Tulane Studies Geol. 5:93-131.

BRÖNNIMANN, P., MARTINI, E., RESIG, J., RIEDEL, W. R., SANFILIPPO, A., and WORSLEY, T., 1971. Biostratigraphic synthesis: Late Oligocene and Neogene of the western tropical Pacific. In: Winterer, E. L., et al., Initial Reports of the Deep Sea Drilling Project, Volume 7(2): 1723-1745. Washington, D.C.: U.S. Government Printing Office.

BRÖNNIMANN, P., and STRADNER, H., 1960. Die Foraminiferen- und Discoasteridenzonen von Kuba und ihre interkontinentale Korrelation. Erdoel Zeitschr., 76:364-369.

BUKRY, D., 1971a. Coccolith stratigraphy, Leg 8, Deep Sea Drilling Project. In: Tracey, J. I., Jr., et al., Initial Reports of the Deep Sea Drilling Project, Volume 8:791-807. Washington, D.C.: U.S. Government Printing Office.
- 1971b. Cenozoic calcareous nannofossils from the Pacific Ocean. San Diego Soc. Natl. Hist., Trans., 16:303-327.

1973a. Coccolith stratigraphy, eastern equatorial Pacific, Leg 16 Deep Sea Drilling Project. In: van Andel, T. H., Heath, G. R., et al., Initial Reports of the Deep Sea Drilling Project, Volume 16:653-711. Washington, D.C.: U.S. Government Printing Office.

1973b. Low-latitude coccolith biostratigraphic zonation. In: Edgar, N. T., Saunders, J. B., et al., Initial Reports of the Deep Sea Drilling Project, Volume 15:685-703. Washington, D.C.: U.S. Government Printing Office.

, 1975. Silicoflagellate and coccolith stratigraphy, Deep Sea Drilling Project Leg 29. In: Kennett, J. P., Houtz, R. E., et al., Initial Reports of the Deep Sea Drilling Project, Volume 29:845-872. Washington, D.C.: U.S. Government Printing Office.

1976a. Cenozoic silicoflagellate and coccolith stratigraphy, South Atlantic Ocean, Deep Sea Drilling Project Leg 35. In: Hollister, C. D., Craddock, C., et al., Initial Reports of the Deep Sea Drilling Project, Volume 35:885-917. Washington, D.C.: U.S. Government Printing Office.

- 1976b. Silicoflagellate and coccolith stratigraphy, NorwegianGreenland Sea, Deep Sea Drilling Project Leg 38. In: Talwani, M., Udintsev, G., et al., Initial Reports of the Deep Sea Drilling Project, Volume 38:843-855. Washington, D.C.: U.S. Government Printing Office.

1977. Coccolith and silicoflagellate stratigraphy, South Atlantic Ocean, Deep Sea Drilling Project Leg 39. In: Supko, P. R., PerchNielsen, K., et al., Initial Reports of the Deep Sea Drilling Project, Volume 39:825-839. Washington, D.C.: U.S. Government Printing Office.

- 1978a. Cenozoic silicoflagellate and coccolith stratigraphy, northwestern Atlantic Ocean, Deep Sea Drilling Project Leg 43. In: Tucholke, B. E., Vogt, P. R., et al., Initial Reports of the Deep Sea Drilling Project, Volume 44:775-805. Washington, D.C.: U.S. Government Printing Office.

1978b. Cenozoic coccolith and silicoflagellate stratigraphy, offshore northwest Africa, Deep Sea Drilling Project Leg 41. In: Lancelot, Y., Seibold, E., et al., Initial Reports of the Deep Sea Drilling Project, Volume 41:689-707. Washington, D.C.: U.S. Government Printing Office.

\section{PLATE 6}

Kellogg Shale diatoms

1-2 Craspedodiscus oblongus (Greville) Grunow

1 , sample CD-13, length $60 \mu \mathrm{m}$, high and low focus; 2 , sample CD-16, length $82 \mu \mathrm{m}$.

3-4 Coscinodiscus tuberculatus var. atlantica Glezer \& Jousé

3 , sample CD-11, diameter $35 \mu \mathrm{m} ; 4$, sample CD11, diameter $41 \mu \mathrm{m}$.

5 Triceratium inconspicuum Greville Sample CD-15, side $11 \mu \mathrm{m}$.
6-7 Triceratium inconspicuum var. trilobata Fenner 6 , sample CD-8, base $12 \mu \mathrm{m} ; 7$, sample CD-6, base $13 \mu \mathrm{m}$.

8, 10 Triceratium $\mathrm{sp}$. aff. T. inconspicuum var. trilobata Fenner

8, sample CD-18, base $24 \mu \mathrm{m} ; 10$, sample CD-16, base $31 \mu \mathrm{m}$.

9 Triceratium kanayae Fenner Sample CD-17, base $28 \mu \mathrm{m}$. 

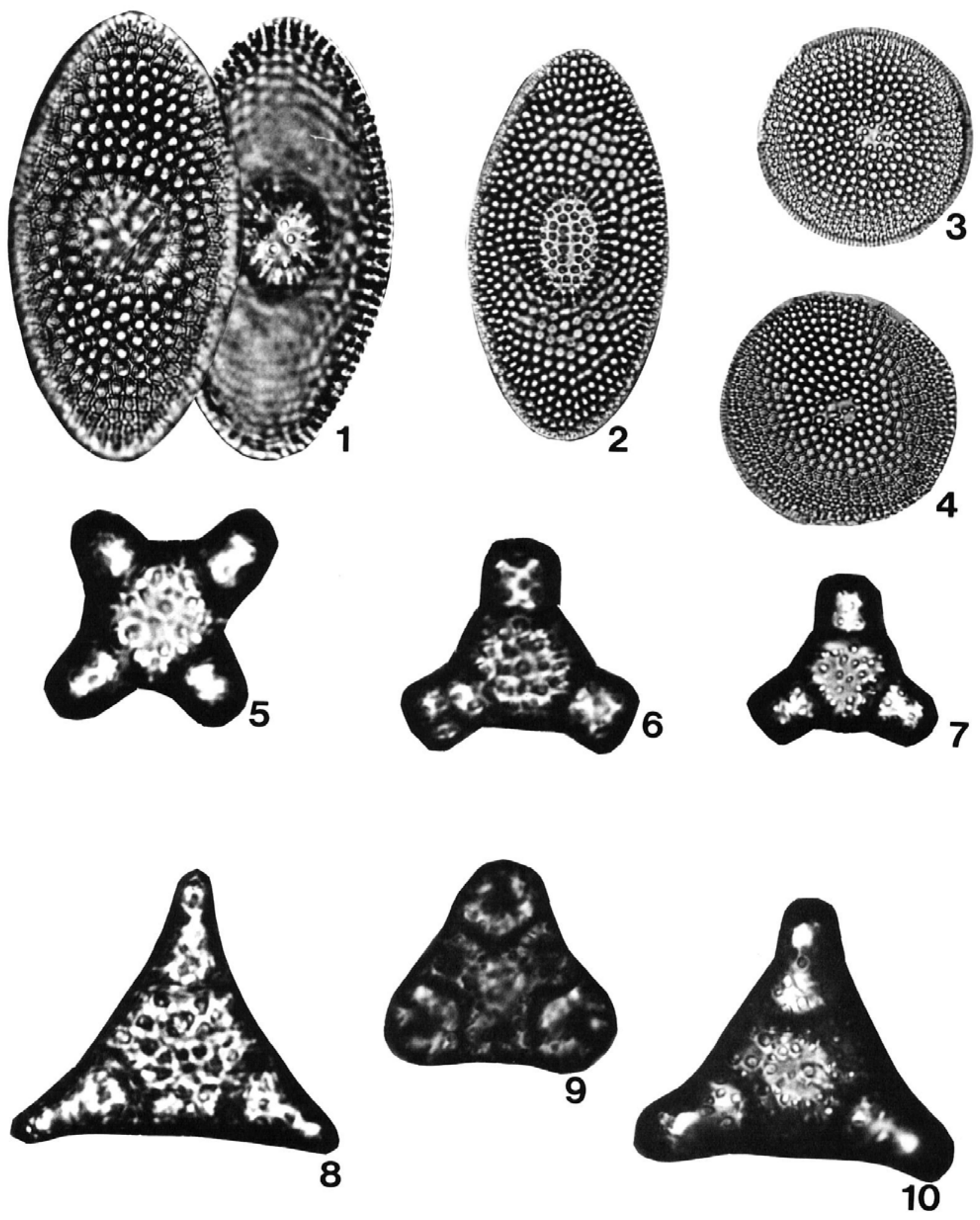
1978c. Cenozoic coccolith, silicoflagellate, and diatom stratigraphy, Deep Sea Drilling Project Leg 44. In: Benson, W. E., Sheridan, R. E., et al., Initial Reports of the Deep Sea Drilling Project, Volume 44:807-863. Washington, D.C.: U.S. Government Printing Office.

1981a. Synthesis of silicoflagellate stratigraphy for Maestrichtian to Quaternary marine sediment. Soc. Econ. Pal. Min., Spec. Publ., 32:433-444.

_ 1981b. Silicoflagellate stratigraphy of offshore California and Baja California, Deep Sea Drilling Project Leg 63. In: Yeats, R. S., Haq, B. U., et al., Initial Reports of the Deep Sea Drilling Project, Volume 63:539-557. Washington, D.C.: U.S. Government Printing Office.

BUKRY, D., and BRAMLETTE, M. N., 1969. Some new and stratigraphically useful calcareous nannofossils of the Cenozoic. Tulane Studies Geol. Pal., 7:131-142.

BUKRY, D., DOUGLAS, R. G., KLING, S. A., and KRASHENINNIKOV, V., 1971. Planktonic microfossil biostratigraphy of the northwestern Pacific Ocean. In: Fischer, A. G., Heezen, B. C., et al., Initial Reports of the Deep Sea Drilling Project, Volume 6:1253-1300. Washington, D.C.: U.S. Government Printing Office.

BUKRY, D., and FOSTER, J. H., 1973. Silicoflagellate and diatom stratigraphy, Leg 16, Deep Sea Drilling Project. In: van Andel, T. H., Heath, G. R., et al., Initial Reports of the Deep Sea Drilling Project, Volume 16:815-871. Washington, D.C.: U.S. Government Printing Office.

1974. Silicoflagellate zonation of Upper Cretaceous to lower Miocene deep-sea sediment. U.S. Geol. Surv., Jour. Res., 2:303-310.

CLARK, B. L., and CAMPBELL, A. S., 1942. Eocene radiolarian faunas from the Mt. Diablo area, California. Geol. Soc. Amer., Spec. Paper, 39:112 pp., 9 pls.

COLBURN, I. P., 1964. The Mesozoic stratigraphy in the vicinity of Mt. Diablo, California. In: Guidebook and Field Trip to the Mt. Diablo Area, Geol. Soc. Amer., Sacramento, 9-13.

DEFLANDRE, G., 1938. Sur deux microfossiles siliceux énigmatiques (Silicoflagellidées?). Soc. Française Microsc., Bull., 7:90-96.

1950. Contribution à l'étude des silicoflagellidés actuels et fossiles. Microscopie, 2:72-108, 117-142, 191-210.
1959. Sur les nannofossiles calcaires et leur systématique. Rev. Micropal., 2:127-152.

DEFLANDRE, G., and FERT, C., 1954. Observations sur les Coccolithophoridés actuels et fossiles en microscopie ordinaire et électronique. Ann. Pal., 40:115-176.

DIBBLEE, T. W., JR., 1980. Preliminary geologic map of the Byron Hot Springs Quadrangle, Alameda and Contra Costa Counties, California. U.S. Geol. Surv., Open File Rept., 80-534.

DUMOULIN, J. A., 1979. Eocene-Oligocene silicoflagellates of the Kreyenhagen Formation, Fresno County, California. University of Wisconsin, Madison, M.S. thesis, $158 \mathrm{pp}$.

EHRENBERG, C. G., 1839. Über die Bildung der Kreidefelsen und des Kreidemergels durch unsichtbare Organismen. K. Akad. Wiss. Berlin, Abh., Jahr 1838 (1840, separate 1839), 59-148.

_ 1840. 274 Blătter von ihm selbst ausgefuhrter Zeichnungen von ebenso vielen Arten. K. Preuss. Akad. Wiss. Berlin, Ber., 1840:197219 (Nov.).

_ 1844. Mittheilung über zwei neue Lager von Gebirgsmassen aus Infusorien als Meeres-Absatz in Nord-Amerika und eine Vergleichung derselben mit den organischen Kreide-Gebilden in Europa und Afrika. K. Preuss. Akad. Wiss. Berlin Ber., 1844:57-97.

_ 1854. Mikrogeologie. Leipzig: Leopold Voss, 1-374

EHRLICH, A., and MOSHKOVITZ, S., 1982. On the occurrence of Eocene marine diatoms in Israel. Acta Geologica Academiae Scientarum Hungaricae, 25(1-2):23-37.

FENNER, J., 1977. Cenozoic diatom biostratigraphy of the equatorial and southern Atlantic Ocean. In: Supko, P. R., Perch-Nielsen, K., et al. Initial Reports of the Deep Sea Drilling Project, Volume 39:491624. Washington, D.C.: U.S. Government Printing Office.

FRENGUELLI, J., 1940. Consideraciones sobre los silicoflagelados fosiles. Mus. La Plata Rev., Pal., 2(7):37-112.

FULMER, C. B., 1954. Stratigraphy and paleontology of the typical Markley and Nortonville Formations of central California. Geol. Soc. Amer., Bull., 65:1341 (abstr.).

GARTNER, S., 1970. Phylogenetic lineages in the lower Tertiary coc colith genus Chiasmolithus. North Amer. Pal. Convention Proc., pt. G:930-957.

\section{PLATE 7}

Eocene diatoms

\section{1-3 Melosira architecturalis Brun}

1 , sample CD-8, diameter $18 \mu \mathrm{m}$; 2, sample CD-

16, diameter $23 \mu \mathrm{m} ; 3$, sample CD-8, diameter 22 $\mu \mathrm{m}$.

4 Melosira sulcata (Ehrenberg) Kützing

Sample CD-18, diameter $19 \mu \mathrm{m}$.

5 Thalassiosira sp. 1

Sample CD-8, diameter $18 \mu \mathrm{m}$.

6 Thalassiosira sp. 2

Sample CD-8, diameter $33 \mu \mathrm{m}$.

7 Stephanopyxis turris (Greville \& Arnott) Ralfs Sample CD-11, length $30 \mu \mathrm{m}$.
8 Actinoptychus undulatus (Bailey) Ralfs

Sample CD-16, diameter $43 \mu \mathrm{m}$.

9 Pseudopodosira bella Glezer \& Posnova Sample CD-15, diameter $17 \mu \mathrm{m}$.

10 Coscinodiscus argus var. 1 Sample DSDP 208-28-6, 42-45 cm, diameter 41 $\mu \mathrm{m}$.

12 Coscinodiscus marginatus Ehrenberg Sample CD-8, diameter $48 \mu \mathrm{m}$, high and low focus. 

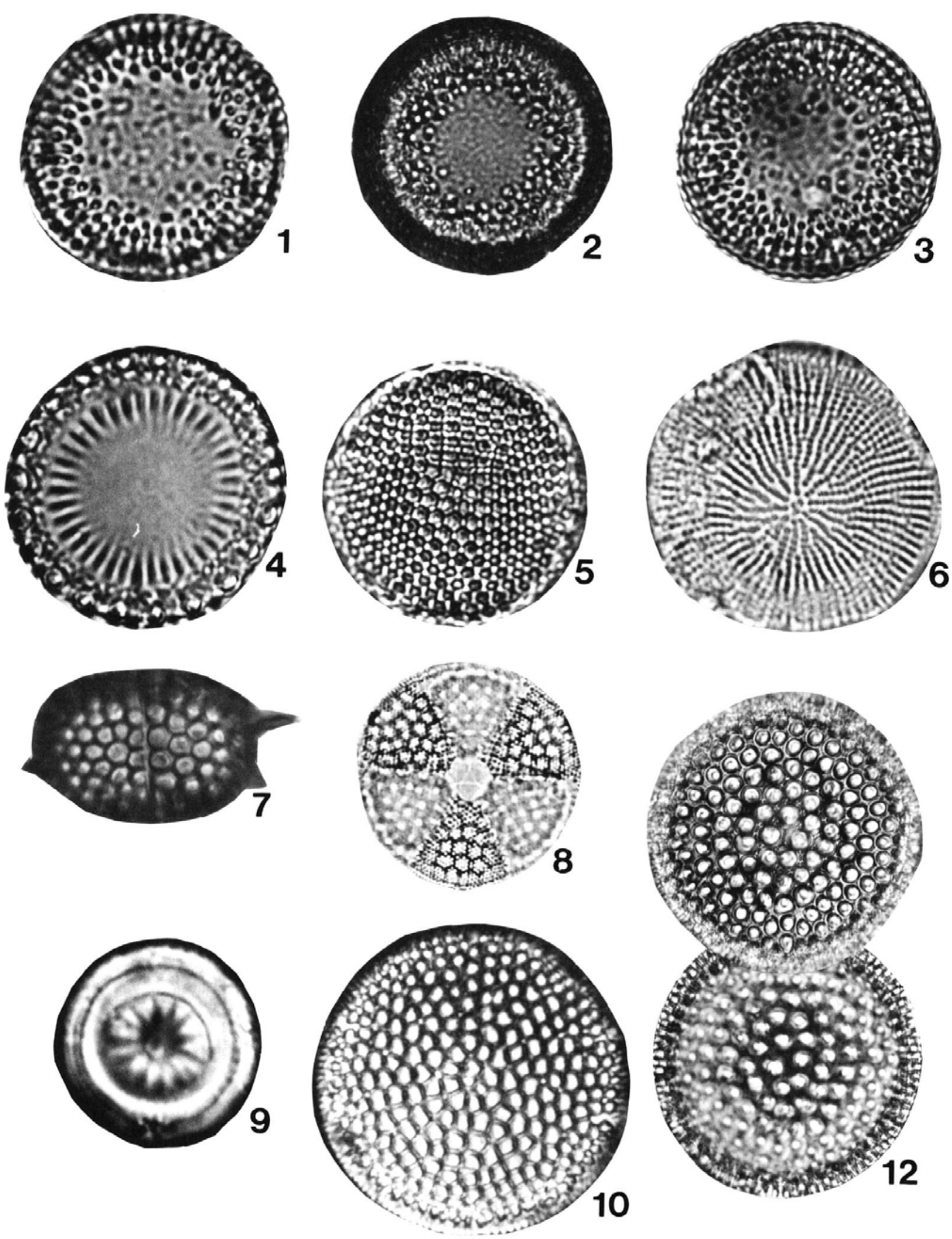
GLEZER, Z. I., 1964. Novye kremnevye zhgutikovye vodorosli Paleogena SSSR [New silicoflagellates from the Paleogene of the USSR]. Akad. Nauk SSSR, Novosti sistematiki nizshikh rasteniy, Otd. ottisk, 46-58.

— 1966 . Silicoflagellatophyceae. In: Gollerbakh, M. M., Ed., Cryp. togamic plants of the U.S.S.R. Akad. Nauk SSSR, V. A. Komarova Bot. Inst. (Translated from Russian by Israel Program for Scientific Translations Ltd., Jerusalem, 1970), 7:1-363.

GRASSÉ, P. P., 1952. Traité de zoologie. Anatomie, systématique, biologie. Tome 1, fasc. 1. Paris: Masson, $1071 \mathrm{pp}$.

HAECKEL, E. H. P. A., 1887. Cannorrhaphida. Challenger Rept., 18 : 1546-1569.

HANNA, G. D., 1931. Diatoms and silicoflagellates of the Kreyenhagen shale. California Div. Mines, State Mineralogist Rept., 27:187-201.

HAQ, B. U., and LOHMANN, G. P., 1976. Early Cenozoic calcareous nannoplankton biogeography of the Atlantic Ocean. Marine Micropal., 1:119-194.

HAY, W. W., and MOHLER, H. P., 1967. Calcareous nannoplankton from early Tertiary rocks at Pont Labau, France, and Paleocene-early Eocene correlations. Jour. Pal., 41:1505-1541.

HAY, W. W., MOHLER, H., ROTH, P. H., SCHMIDT, R. R., and BOU DREAUX, J. E., 1967. Calcareous nannoplankton zonation of the Cenozoic of the Gulf Coast and Carribean-Antillean area, and transoce anic correlation. Gulf Coast Assoc. Geol. Soc., Trans., 17:428-480.

HAY, W. W., MOHLER, H., and WADE, M. E., 1966. Calcareous nannofossils from Nal'chik (northwest Caucasus). Eclogae Geol. Helvetiae, 59:379-400

HAY, W. W., and TOWE, K. M., 1962. Electronmicroscopic examination of some coccoliths from Donzacq (France). Eclogae Geol. Helvetiae, 55:497-517.

HAYS, J. D., COOK, H. E., III, JENKINS, D. G., COOK, F. M., FULLER, J. T., GOLL, R. M., MLOW, E. D., and ORR, W. N., 1972. Initial
Reports of the Deep Sea Drilling Project, Volume 9:1-1205. Washington, D.C.: U.S. Government Printing Office.

JAFAR, S. A., and MARTINI, E., 1975. On the validity of the calcareous nannoplankton genus Helicosphaera. Senckenbergiana Lethaea, 56: 381-397

JOUSE, A. P., 1979. Diatom biostratigraphic zones of the Eocene. Nova Hedwigia, 64:427-446.

KAMPTNER, E., 1963. Coccolithineen-Skelettreste aus Tiefseeablagerungen des Pazifischen Ozeans. Naturhist. Mus., Wien, Ann., 66:139204.

KANAYA, T., 1957. Eocene diatom assemblages from the Kellogg and "Sidney" shales, Mt. Diablo area, California. Tohoku Univ., Sendai, Japan, Sci. Repts., 2nd ser. (geol.), 28:27-124, 8 pls.

KANAYA, T., and KOIZUMI, I., 1970. The progress in the younger Cenozoic diatom biostratigraphy in the northern circum-Pacific region. Jour. Marine Geol. (Japan), 6:47-66.

KEROHER, G. C., ET AL., 1966. Lexicon of geologic names of the United States for 1936-1960. U.S. Geol. Surv., Bull., 1200(2):14492886.

LAIMING, B., 1940. Some foraminiferal correlations in the Eocene of San Joaquin Valley, California. Pacific Sci. Congr., 6th, 1939, Proc., 2:535-568.

LEMMERMANN, E., 1901. Silicoflagellatae. Deutsche Bot. Ges. Ber., 19: 247-271.

LEVIN, H. L., 1965. Coccolithophoridae and related microfossils from the Yazoo Formation (Eocene) of Mississippi. Jour. Pal., 39(2):265272.

LEVIN, H. L., and JOERGER, A. P., 1967. Calcareous nannoplankton from the Tertiary of Alabama. Micropaleontology, 13(2):163-182.

LING. H. Y., 1972. Upper Cretaceous and Cenozoic silicoflagellates and ebridians. Bull. Amer. Pal., 62:135-229.

PLATE 8

Kellogg Shale diatoms

1 Chaetoceros spine

Sample CD-11, length $112 \mu \mathrm{m}$.

2 Riedelia sp. 1

Sample CD-16, length $142 \mu \mathrm{m}$.

3, 5 Hemiaulus polycystinorum var. mesolepta Grunow 3 , sample CD-8, base $35 \mu \mathrm{m} ; 5$, sample CD-8, base $72 \mu \mathrm{m}$.

4 Riedelia claviger (Schmidt) Schrader \& Fenner Sample CD-16, base $23 \mu \mathrm{m}$.

6 Rhizosolenia sp. 1 Sample CD-11, length $81 \mu \mathrm{m}$.

7 Pyxilla gracilis Tempère \& Forti Sample CD-8, length $88 \mu \mathrm{m}$.
8 Navicula sp. (a benthic diatom) Sample CD-11, length $71 \mu \mathrm{m}$.

9 Sceptroneis sp. cf. S. talwanii Schrader \& Fenner Sample CD-8, length of fragment $19 \mu \mathrm{m}$.

10 Pterotheca danica (Grunow) Forti Sample CD-8, length $70 \mu \mathrm{m}$.

11 Pterotheca gracillima Fenner Sample CD-8, base $8 \mu \mathrm{m}$.

12 Pterotheca sp. Sample CD-8, base $8 \mu \mathrm{m}$.

13 Pterotheca aculeifera (Grunow) Van Heurck Sample CD-8, base $7 \mu \mathrm{m}$. 

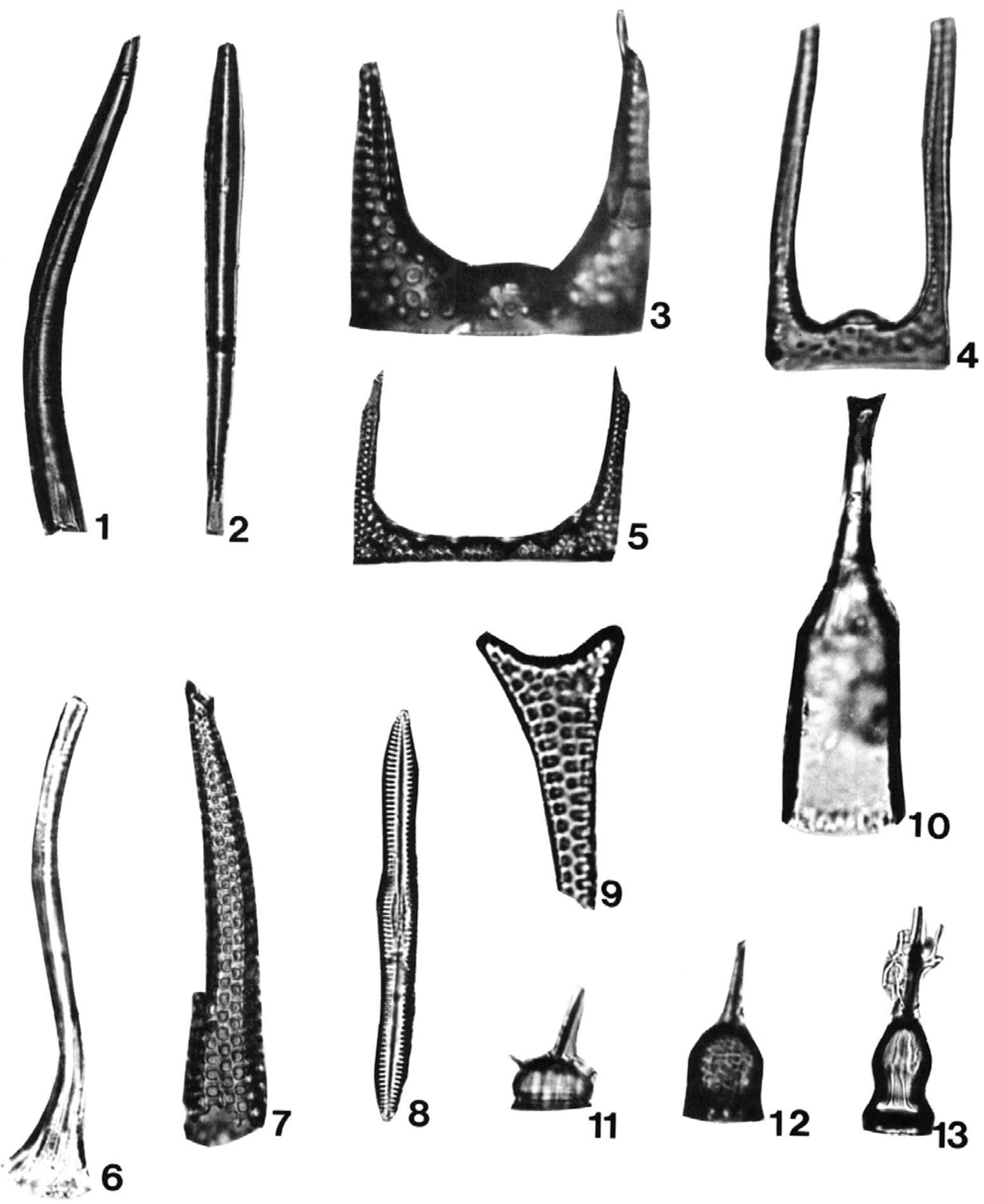
LOCKER, S., 1974. Revision der Silicoflagellaten aus der mikrogeologischen Sammlung von C. G. Ehrenberg. Eclogae Geol. Helvetiae, 67:631-646.

LOEBLICH, A. R., 3d, LOEBLICH, L. A., TAPPAN, H., and LOEBLICH A. R., JR., 1968. Annotated index of fossil and Recent silicoflagellates and ebridians with descriptions and illustrations of validly proposed taxa. Geol. Soc. Amer., Mem., 106:319 pp.

LOWRIE, W., ALVAREZ, W., NAPOLEONE, G., PERCH-NIELSEN, K., PREMOLI-SILVA, I., and TOUMARKINE, M., 1982. Paleogene magnetic stratigraphy in Umbrian pelagic carbonate rocks. The Contessa sections, Gubbio. Geol. Soc. Amer., Bull., 93:414-432.

MALLORY, V. S., 1959. Lower Tertiary biostratigraphy of the California Coast Ranges. Amer. Assoc. Petrol. Geol., Tulsa, Oklahoma, 416 pp.

MANDRA, Y. T., 1960. Fossil silicoflagellates from California, U.S.A. Internat. Geol. Congr., 21st, Copenhagen 1960, pt. 6:77-89.

1968. Silicoflagellates from the Cretaceous, Eocene, and Miocene of California, U.S.A. California Acad. Sci., Proc., 36:231-277.

MARTINI, E., 1958. Discoasteriden und verwandte Formen im NWdeutschen Eozăn (Coccolithophorida). Senckenbergiana Lethaea, 39: 353-388.

1961. Nannoplankton aus dem Tertiär und der obersten Kreide von SW-Frankreich. Senckenbergiana Lethaea, 42:1-32.

1974. Silicoflagellate zones in the Eocene and early Oligocene. Senckenbergiana Lethaea, 54:527-532.

1981. Silicoflagellaten im Paläogen von Norddeutschland. Senckenbergiana Lethaea, 62:277-283.

MARTINI, E., and MULLER, C., 1976. Eocene to Pleistocene silicoflagellates from the Norwegian-Greenland Sea (DSDP Leg 38). In: Talwani, M., Udintsev, G., et al., Initial Reports of the Deep Sea Drilling Project, Volume 38:857-895. Washington, D.C.: U.S. Government Printing Office.

MARTINI, E., and RITZKOWSKI, S., 1968. Was ist das "Unter-Oligozan"?. Akad. Wiss. Gottingen Nachr., Math.-Phys. KI., 13:231-250.

MCKEEL, D. R., and LIPPS, J. H., 1975. Eocene and Oligocene planktonic foraminifera from the central and southern Oregon Coast Range. Jour. Foram. Res., 5:249-269.

MÜLLER, C., 1970. Nannoplankton-Zonen der untern Meeresmolasse Bayerns. Geol. Bavarica, 63:107-118.
1979. Calcareous nannofossils from the North Atlantic (Leg 48). In: Montadert, L., Roberts, D. G., et al., Initial Reports of the Deep Sea Drilling Project, Volume 48:589-620. Washington, D.C.: U.S. Government Printing Office.

OKADA, H., and BUKRY, D., 1980. Supplementary modification and introduction of code numbers to the low-latitude coccolith biostratigraphic zonation (Bukry 1973; 1975). Marine Micropal., 5:321-325.

PERCH-NIELSEN, K., 1967. Nannofossilien aus dem Eozăn von Danemark. Eclogae Geol. Helvetiae, 60:19-32.

1971. Elektronenmikroskopische Untersuchungen an Coccolithen und verwandten Formen aus dem Eozăn von Danemark. Biol. Skr. Danske Vidensk. Selsk., 18:1-76.

_ 1975. Late Cretaceous to Pleistocene silicoflagellates from the southern southwest Pacific, DSDP Leg 29. In: Kennett, J. P., Houtz, R. E., et al., Initial Reports of the Deep Sea Drilling Project, Volume 29:677-721. Washington, D.C.: U.S. Government Printing Office.

1976. New silicoflagellates and a silicoflagellate zonation in north European Palaeocene and Eocene diatomites. Geol. Soc. Denmark, Bull., 25:27-40.

PERCH-NIELSEN, K., and FRANZ, H. E., 1977. Lapideacassis and Scampanella, calcareous nannofossils from the Paleocene at Sites 354 and 356, DSDP Leg 39, Southern Atlantic. In: Supko, P. R., PerchNielsen, K., et al., Initial Reports of the Deep Sea Drilling Project, Volume 39:849-862. Washington, D.C.: U.S. Government Printing Office.

POORE, R. Z., 1976. Microfossil correlation of California Lower Tertiary sections: A comparison. U.S. Geol. Surv., Prof. Paper, 743-F:8 pp.

POORE, R. Z., BARRON, J. A., and ADDICOTT, W. O., 1981. Biochronology of the northern Pacific Miocene. In: Ikebe, N., et al., Proceedings of International Geological Correlations Program, Project 114: International Workshop on Pacific Neogene Biostratigraphy, 6th International Working Group Meeting, November 2-5, 1981, Osaka, Japan, 91-98.

POORE, R. Z., and BRABB, E. E., 1977. Eocene and Oligocene planktonic foraminifera from the upper Butano Sandstone and type San Lorenzo Formation, Santa Cruz Mountains, California. Jour. Foram. Res., 7(4):249-272.

RADOMSKI, A., 1968. Calcareous nannoplankton zones in Palaeogene of the Western Polish Carpathians. Polskiego Tow. Geol., Rocz., 38 : $545-605$.

\section{PLATE 9}

Planktonic foraminifers from the Kellogg Shale. Figures 9 and 12 are from sample CD-5. All others are from sample CD11. Scale bar for figures 2 and 4 equals $10 \mu \mathrm{m}$. Scale bar for all others equals $100 \mu \mathrm{m}$.

1-3 Pseudohastigerina danvillensis (Howe \& Wallace)

1 , side view; 2 , close-up of aperture of figure 1 ; 3 , edge view.

4 Guembelitria columbiana Howe Side view.

5-6 Subbotina eocaenica (Terquem) sensu Blow 1979

5 , umbilical view; 6 , spiral view.
7-8 Acarinina soldadoensis (Brönnimann)

7, umbilical view; 8 , spiral view.

9,12 Globorotaloides wilsoni (Cole)

9, umbilical view; 12, edge view.

10-11 Acarinina aspensis (Colom)

10 , umbilical view; 11 , spiral view. 


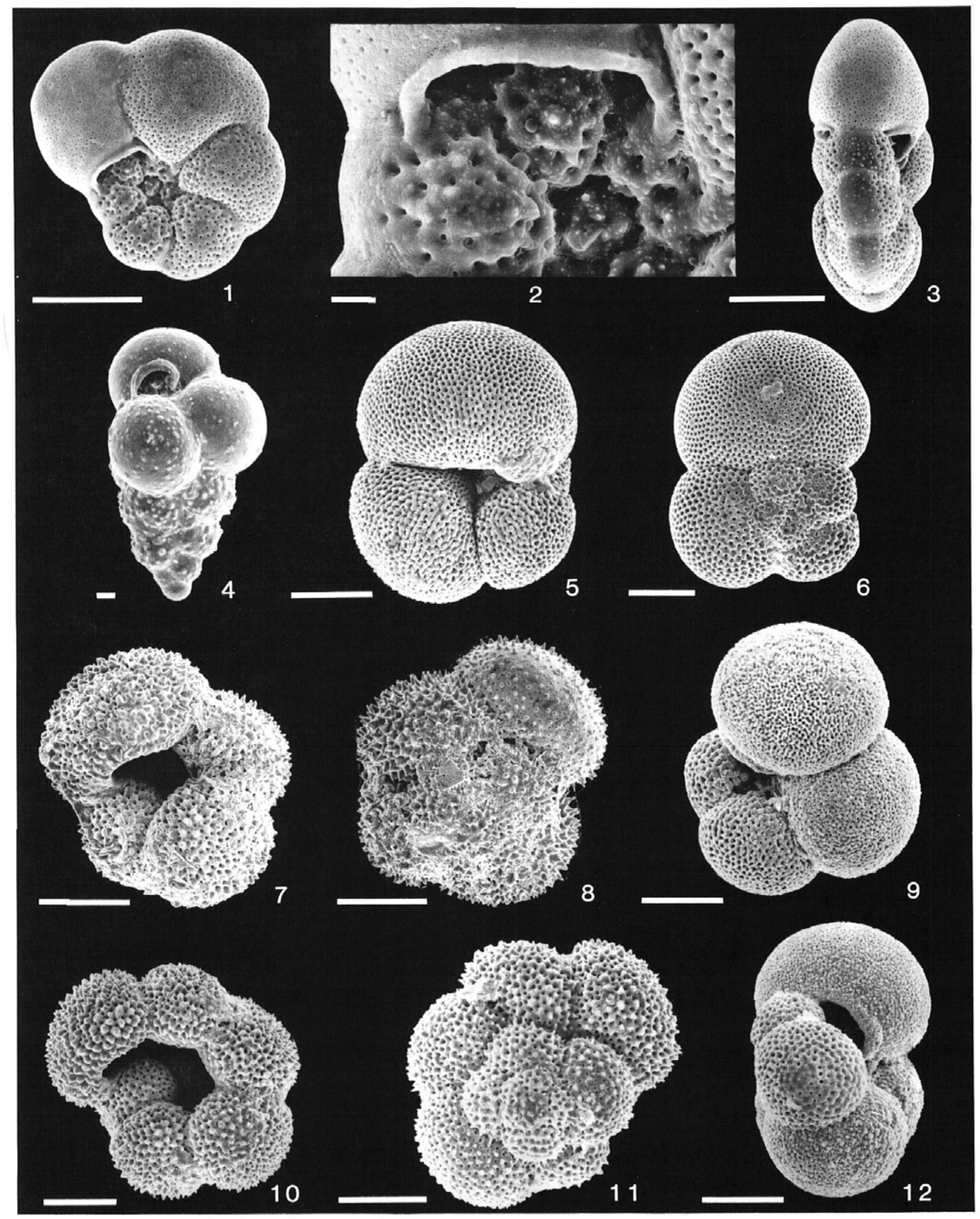


ROTH, P. H., 1970. Oligocene calcareous nannoplankton biostratigraphy. Eclogae Geol. Helvetiae, 63:799-881.

SCHILLER, J., 1930. Coccolithineae. In: Rabenhorst, L., Ed., Kryptogamen-Flora von Deutschland, Osterreich und der Schweiz, 10(2):89267. Leipzig: Akademische Verlagsgesellschaft.

SCHMIDT, A., 1874-1959. Atlas der Diatomaceenkunde, pls. 1-480. Leipzig: O. R. Resiland.

SCHMIDT, R. R., 1970. Planktonic foraminifera from the lower Tertiary of California. University of California, Los Angeles, unpubl. PhD. dissertation, $339 \mathrm{pp}$.

SCHRADER, H. J., 1978. Diatoms in DSDP Leg 41 sites. In: Lancelot, Y., Seibold, E., et al., Initial Reports of the Deep Sea Drilling Project, Volume 41:791-812. Washington, D.C.: U.S. Government Printing Office.

SCHRADER, H. J., and FENNER, J., 1976. Norwegian Sea Cenozoic diatom biostratigraphy and taxonomy. In: Talwani, M., Udintsev, G., et al., Initial Reports of the Deep Sea Drilling Project, Volume 38:9211099. Washington, D.C.: U.S. Government Printing Office.

SCHULZ, P., 1928. Beitrăge zur Kenntnis fossiler und rezenter Silicoflagellaten. Bot. Archiv., 21:225-292.

SLITER, W. V., 1972. Upper Cretaceous planktonic foraminiferal zoogeography and ecology-eastern Pacific margin. Palaeogeogr., Palaeoclimatol., Palaeoecol., 12:3-17.
STAINFORTH, R. M., LAMB, J. L., LUTERBACHER, H., BEARD, J. H., and JEFFORDS, R. M., 1975. Cenozoic planktonic foraminiferal zonation and characteristics of index forms. Kansas, Univ., Pal. Contr., 62:1-425.

STRADNER, H., 1959. Die fossilen Discoasteriden Österreichs II. Teil. Erdoel Zeitschr., 75:472-488.

1961. Vorkommen von Nannofossilien im Mesozoikum und Alttertiär. Erdoel Zeitschr. 77:77-88.

SULLIVAN, F. R., 1964. Lower Tertiary nannoplankton from the California Coast Ranges. Pt. 1, Paleocene. California, Univ., Publ. Geol. Sci., 44(3):163-228.

TAN, S. H., 1927. Discoasteridae incertae sedis. Koninkl. Akad. Wetensch. Amsterdam, Proc., Sec. Sci., 30(3):411-419.

WALLICH, G. C., 1877. Observations on the coccosphere. Ann. Mag. Nat. Hist., ser. 4, 19:342-350.

WISE, S. W., JR., 1973. Calcareous nannofossils from cores recovered during Leg 18, Deep Sea Drilling Project: Biostratigraphy and observations of diagenesis. In: Kulm, L. D., von Huene, R., et al., Initial Reports of the Deep Sea Drilling Project, Volume 18:569-615. Washington, D.C.: U.S. Government Printing Office.

Manuscript received March 14, 1983.

Revised manuscript accepted June 1, 1983. 